\title{
HemisFair Park, San Antonio, Texas: An Archival Study for the Convention Center Expansion
}

Edgar D. Johnson

Center for Archaeological Research

I. Waynne Cox

Center for Archaeological Research

C. Britt Bousman

Department of Anthropology, Texas State University

Follow this and additional works at: https://scholarworks.sfasu.edu/ita

Part of the American Material Culture Commons, Archaeological Anthropology Commons, Environmental Studies Commons, Other American Studies Commons, Other Arts and Humanities Commons, Other History of Art, Architecture, and Archaeology Commons, and the United States History Commons

Tell us how this article helped you.

This Article is brought to you for free and open access by the Center for Regional Heritage Research at SFA ScholarWorks. It has been accepted for inclusion in Index of Texas Archaeology: Open Access Gray Literature from the Lone Star State by an authorized editor of SFA ScholarWorks. For more information, please contact cdsscholarworks@sfasu.edu. 


\section{HemisFair Park, San Antonio, Texas: An Archival Study for the Convention Center Expansion}

\section{Creative Commons License}

\section{(c) (1) (8)}

This work is licensed under a Creative Commons Attribution-NonCommercial 4.0 International License 


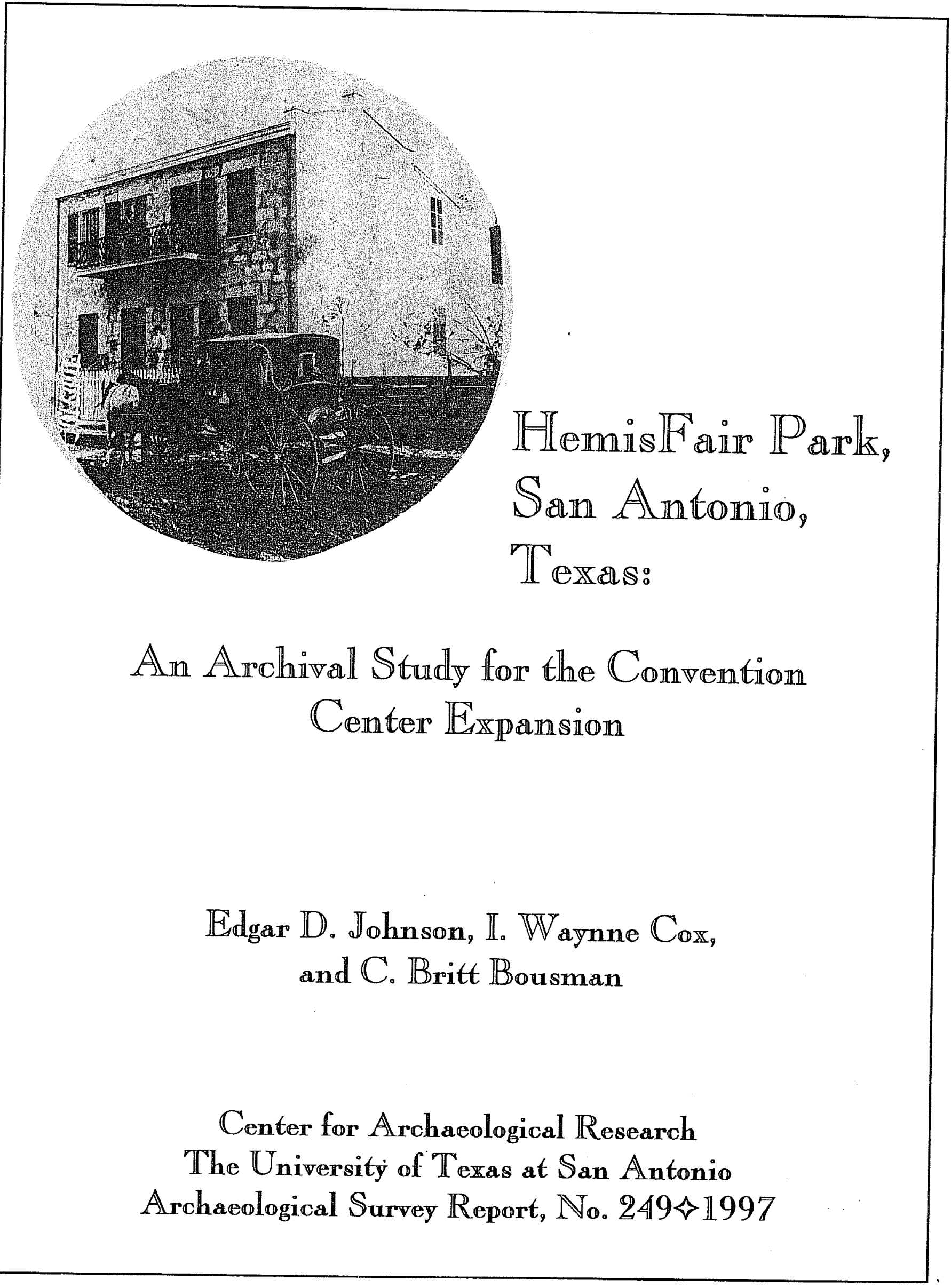




\section{HemisFair Park, San Antonio, Texas: An Archival Study for the Convention Center Expansion}

Edgar D. Johnson, I. Waynne Cox, and C. Britt Bousman

Robert J. Hard and C. Britt Bousman, Principal Investigators

${ }^{(\mathbb{C}}$ copyright

Center for Archaeological Research

The University of Texas at San Antonio

Archaeological Survey Report, No. 249

1997 
The following information is provided in accordance with the General Rules of Practice and Procedure, Chapter 41.11 (Investigative Reports), Texas Antiquities Committee:

1. Type of investigation: archival research

2. Project name: Convention Center Expansion

3. County: Bexar

4. Principal investigators: Robert J. Hard and C. Britt Bousman

5. Name and location of sponsoring agency: City of San Antonio

6. Texas Antiquities Committee Permit No.: n/a

7. Published by the Center for Archaeological Research, The University of Texas at San Antonio, 6900 N. Loop 1604 W., San Antonio, Texas 78249-0658, 1997.

A list of publications offered by the Center for Archaeological Research is available. Call (210) 458-4378; write to the Center for Archaeological Research, The University of Texas at San Antonio, 6900 N. Loop 1604 W., San Antonio, Texas 78249-0658; e-mail to car@lonestar.utsa.edu; or visit CAR's Web site at http://www.csbs.utsa.edu/research/car/index.htm. 


\begin{abstract}
In August and September 1996, the Center for Archaeological Research conducted archival research on the proposed Henry B. Gonzalez Convention Center Expansion in downtown San Antonio, Texas. This area, now in HemisFair Park, was once part of the agricultural fields for the Mission San Antonio de Valero (the Alamo). This report presents a general history of the area, a review of previous archaeological research in HemisFair Park, detailed archival research on nineteenth-century buildings known to be present in the construction area, and recommendations for further archaeological investigations in preparation for the construction of the Convention Center. Also, all known photographs from the Institute of Texan Cultures of nineteenth-century structures in HemisFair Park are published as an appendix.
\end{abstract}




\section{Contents}

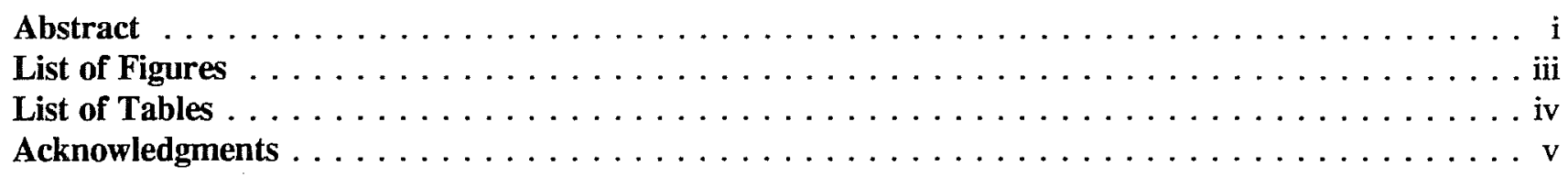

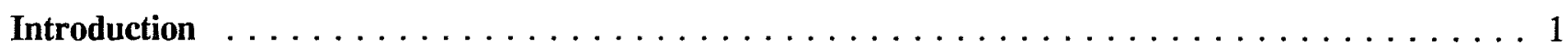

\section{Part I: Historical Background}

The Native American Inhabitants . . . . . . . . . . . . . . . . . . . . 4

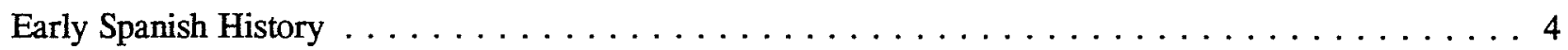

Founding of the Mission and Beginning the Acequia $\ldots \ldots \ldots \ldots \ldots \ldots \ldots \ldots \ldots \ldots \ldots \ldots \ldots$

The Isleños and More Missions $\ldots \ldots \ldots \ldots \ldots \ldots \ldots \ldots \ldots \ldots \ldots \ldots \ldots \ldots \ldots \ldots$

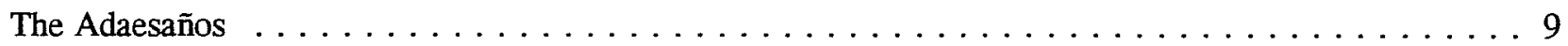

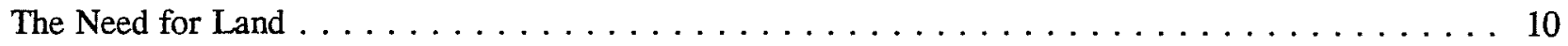

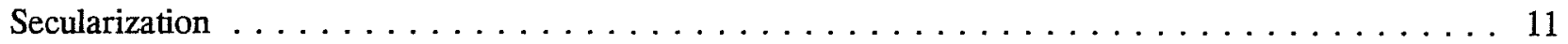

Political Unrest and Revolution . . . . . . . . . . . . . . . . . . . . . 13

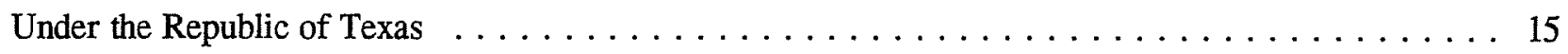

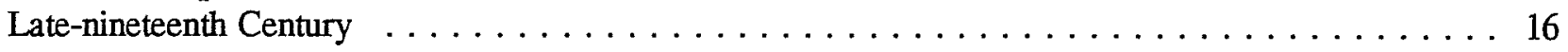

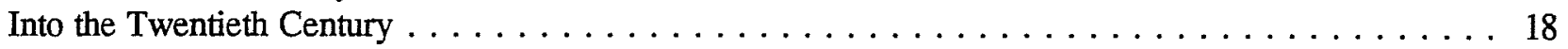

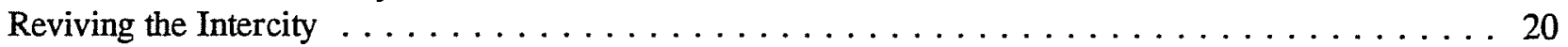

A New Approach: HemisFair . . . . . . . . . . . . . . . . . . . 21

Part II: HemisFair Park and the Project Area

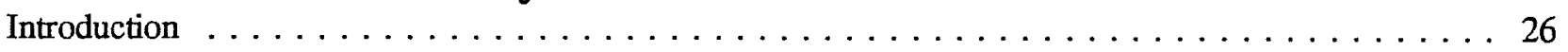

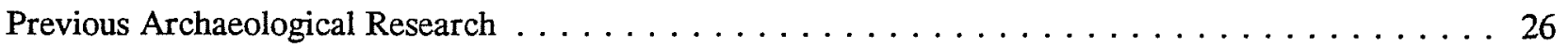

HemisFair Park . . . . . . . . . . . . . . . . . . . . . . . . . . . . . . 29

Lot Histories Within the Construction Area . . . . . . . . . . . . . . . . . . . . . 39

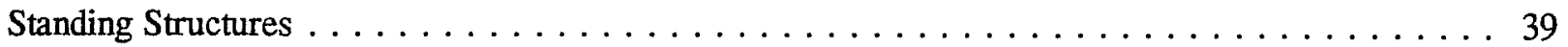

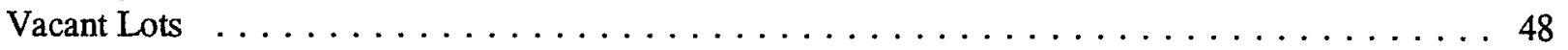

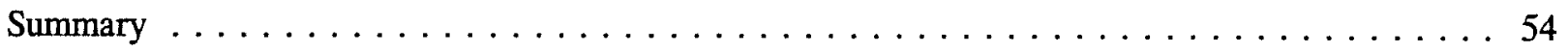

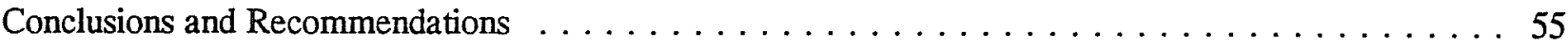

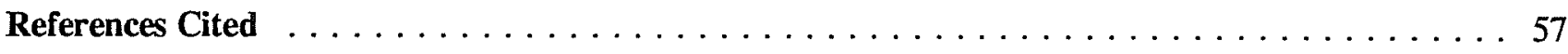

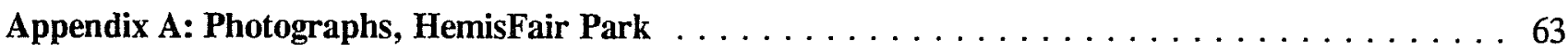

Appendix B: Early Beckville Deed Transactions $\ldots \ldots \ldots \ldots \ldots \ldots$ 


\section{Figures}

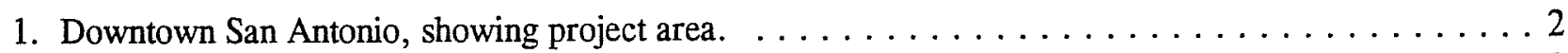

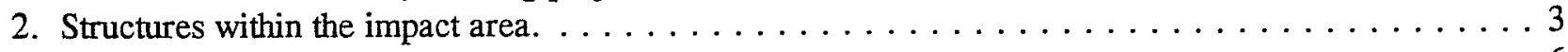

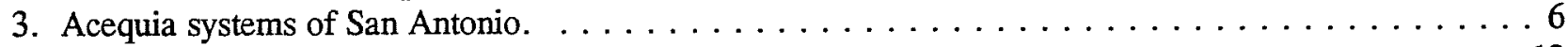

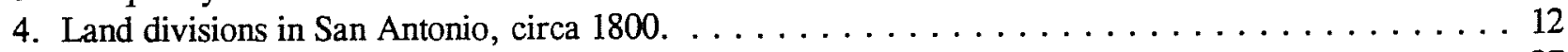

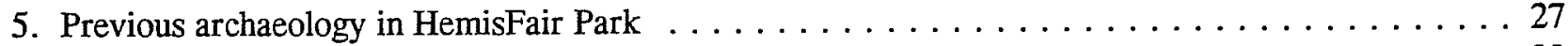

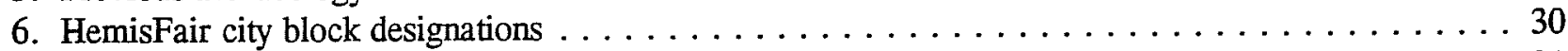

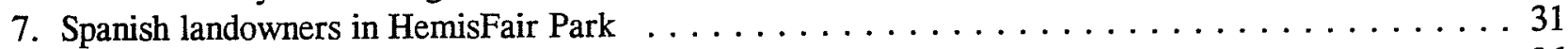

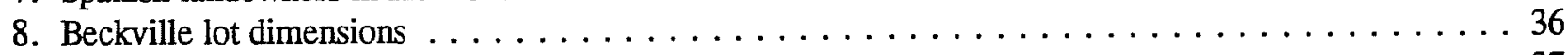

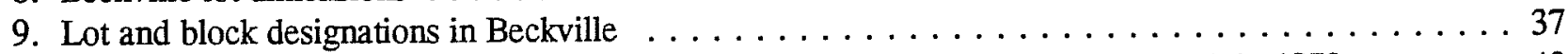

10. Detail from Bird's Eye View of the City of San Antonio, drawn by Augustus Koch in $1873 \ldots$. . . . 40

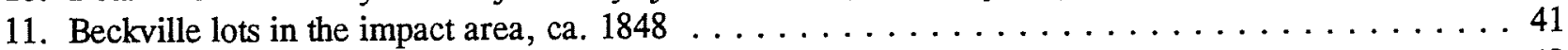

12. Occupied lots in the impact area . . . . . . . . . . . . . . . . . . . 42

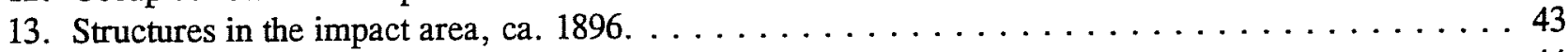

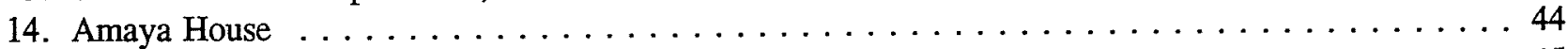

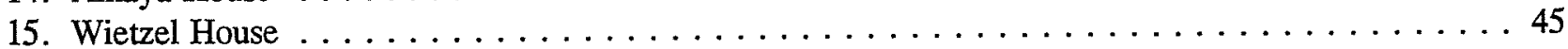

16. 127 Wyoming (Centre). Beck Block 5, Lot . . . . . . . . . . . . . . . . . 46

17. O K Bar . . . . . . . . . . . . . . . . . . . . . . . . . 47

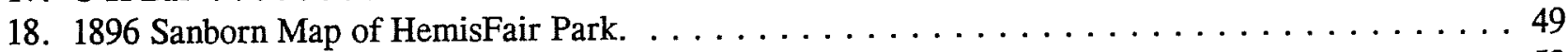

19. 124 Wyoming Street. Beck Block 4 Lot 12 , CB $692 \ldots \ldots \ldots \ldots \ldots \ldots \ldots$

20. 124 Wyoming Street. Beck Block 4 , Lot 12 , CB 692, rear building . . . . . . . . . . . 53

A-1. Photo 1: Kinky and Nando's Grill. 404 South Alamo Street . . . . . . . . . . . . . 63

A-2. Photo 2: Beethoven Hall. 418 South Alamo Street. . . . . . . . . . . . . . . . . 64

A-3. Photo 3: Eager House. 434 South Alamo Street . . . . . . . . . . . . . . . . . . 65

A-4. Photo 4. Eager House. 434 South Alamo Street, rear building . . . . . . . . . . . . 65

A-5. Pereida family in front of their business on Navarro Street $\ldots \ldots \ldots \ldots \ldots \ldots$

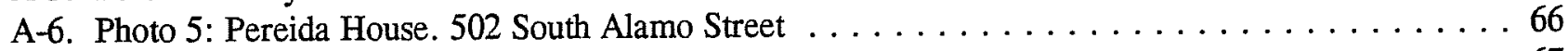

A-7. Photo 6: Garza House. 121 Goliad Street. Demolished . . . . . . . . . . . . . . . . . . 67

A-8. Photo 7: Longini-Herrmann House. 138 Goliad Street . . . . . . . . . . . . . . . . . 67

A-9. Photo 8: M. Halff House. 139 Goliad Street . . . . . . . . . . . . . . . . . . 68

A-10. Photo 9: S. Halff House. 142 Goliad Street $\ldots \ldots \ldots \ldots \ldots \ldots \ldots \ldots \ldots$

A-11. Photo 10: Kusch House. 301 Goliad Street . . . . . . . . . . . . . . . . . . . . . . . 69

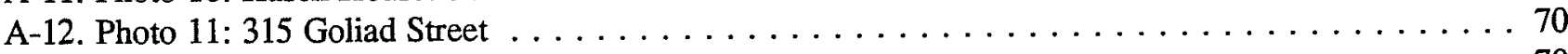

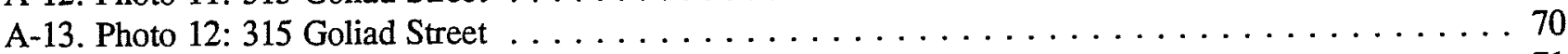

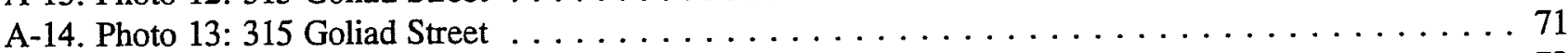

A-15. Photo 14: Max Schultze House. 331 Goliad Street . . . . . . . . . . . . . . . . . 72

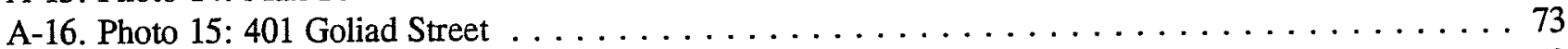

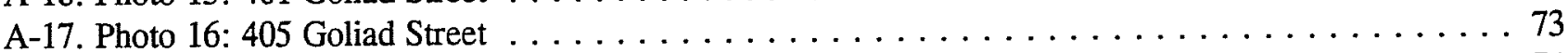

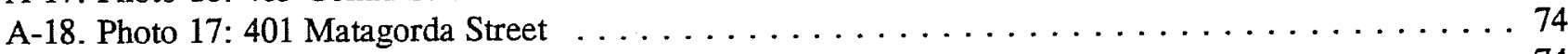

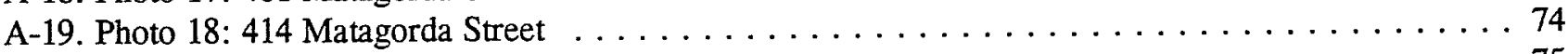

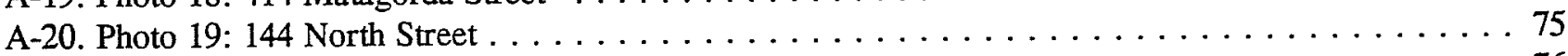

A-21. Photo 20: Original Schultze House. 114 South Street $\ldots \ldots \ldots \ldots \ldots \ldots \ldots \ldots \ldots \ldots \ldots$

A-22. Photo 21: Smith House. 503 Water Street $\ldots \ldots \ldots \ldots \ldots \ldots \ldots \ldots \ldots \ldots \ldots$

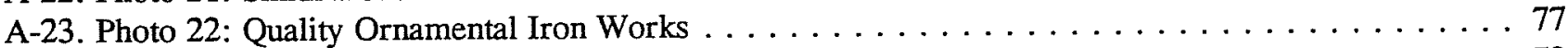

A-24. Photo 23: Duelm House. $232 / 234$ Wyoming Street $\ldots \ldots \ldots \ldots \ldots \ldots \ldots \ldots$

A-25. Map of HemisFair with locations of photographed structures. . . . . . . . . . . . . . 79 


\section{Tables}

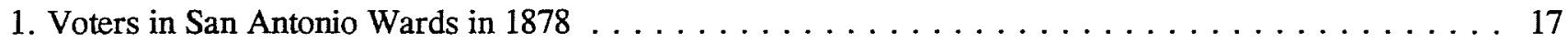

2. Population, Total Real Estate Value, and Per Capita Real Estate by Nationality/Ethnicity in 1878 . . 18

3. Property Ownership within the Convention Center Expansion Area . . . . . . . . . . . . . . 32

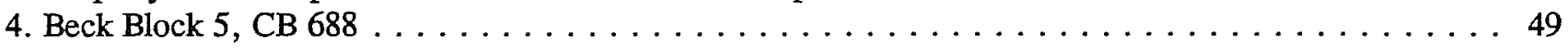

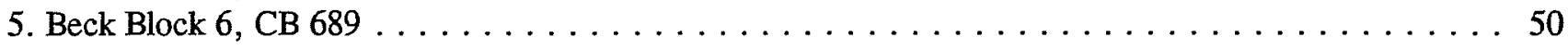

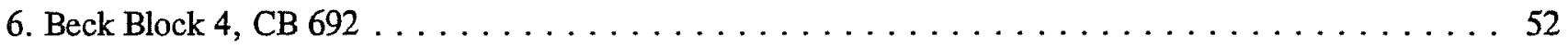

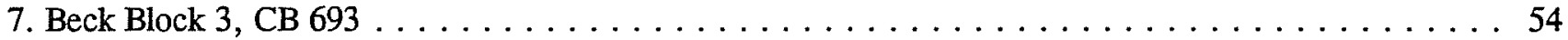




\section{Acknowledgments}

Numerous individuals and institutions assisted in the completion of this project, and we wish to extend our appreciation. City of San Antonio staff members-especially Lisette Murray, Jelynne Burley, Ann McGlone, and Clint McKenzie-provided assistance throughout the entire project. Stewart Title Company, especially plant manager Jody Gill Thomas and customer service representative Lawrence Lockett, helped greatly with the deed records research. Also instrumental in the archival research were Eva Milstead, Nellie Lee Weincek, Barbara Santella, Shirley Donahue, Lupita Fernandez, Agnes Forster, Mary Jackson, June Jump, Dorothy Kvapil, Betty McMurray, Merry Nielsen, and Dolly Ports of the San Antonio Conservation Society Foundation. San Antonio Public Library assisted, as always, in conducting the archival research and assessing documents. The photographs were made available by Diane Bruce of the Institute of Texan Cultures. Also Cliff Croom of the Amaya Deli \& Yogurt House provided information on the structure and its current status. At the Center for Archaeological Research, the able assistance of editor Marcie Renner, administrative assistant Sherri Suñaz, and accountant Jim Lincoln is greatly appreciated. 



\section{Introduction}

In 1996 the city of San Antonio requested an archival study and archaeological assessment of the area that would be affected by expansion of the existing Convention Center. The Convention Center is in the HemisFair area of downtown San Antonio, near several important historic structures (Figure 1). The land that now comprises HemisFair Park was once part of the agricultural fields of the Mission San Antonio de Valero (the Alamo).

The existing arena and a parking garage were scheduled for demolition, and three standing historic structures in the footprint of the new structure would be relocated (Figure 2). CAR had already done substantial research on the three historic structures and the lots to which they were to be moved (Johnson and Cox 1995). Additional data, photographs, and revised relocation sites for those buildings are presented in this report.

Part I of this report presents an overall history of the city of San Antonio. Part II provides archival research specific to HemisFair Park and the impact area, a review of the previous archaeological work in the park, and an assessment of the potential impacts of the planned project on archaeological resources. 


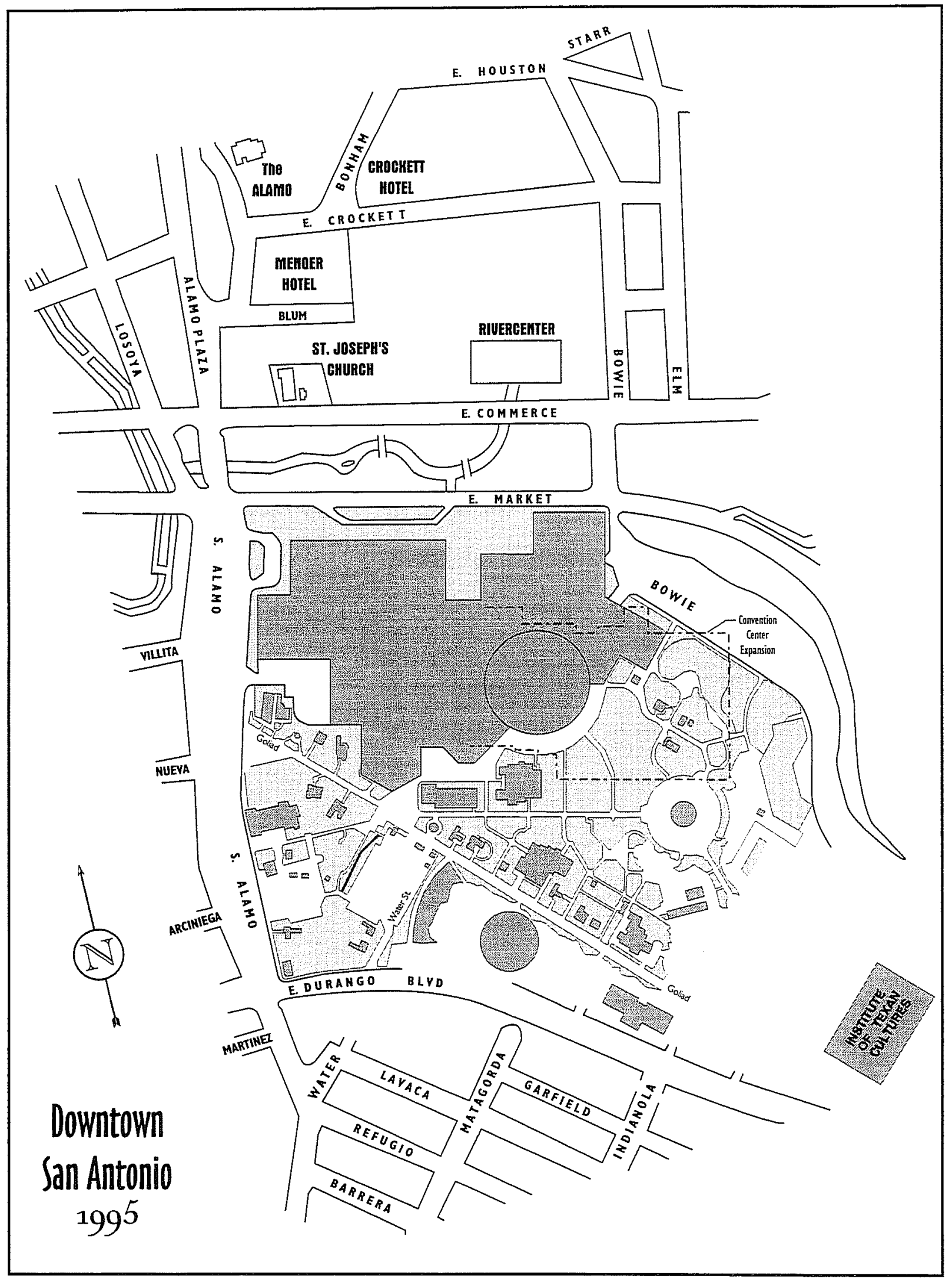

Figure 1. Downtown San Antonio, showing project area. 


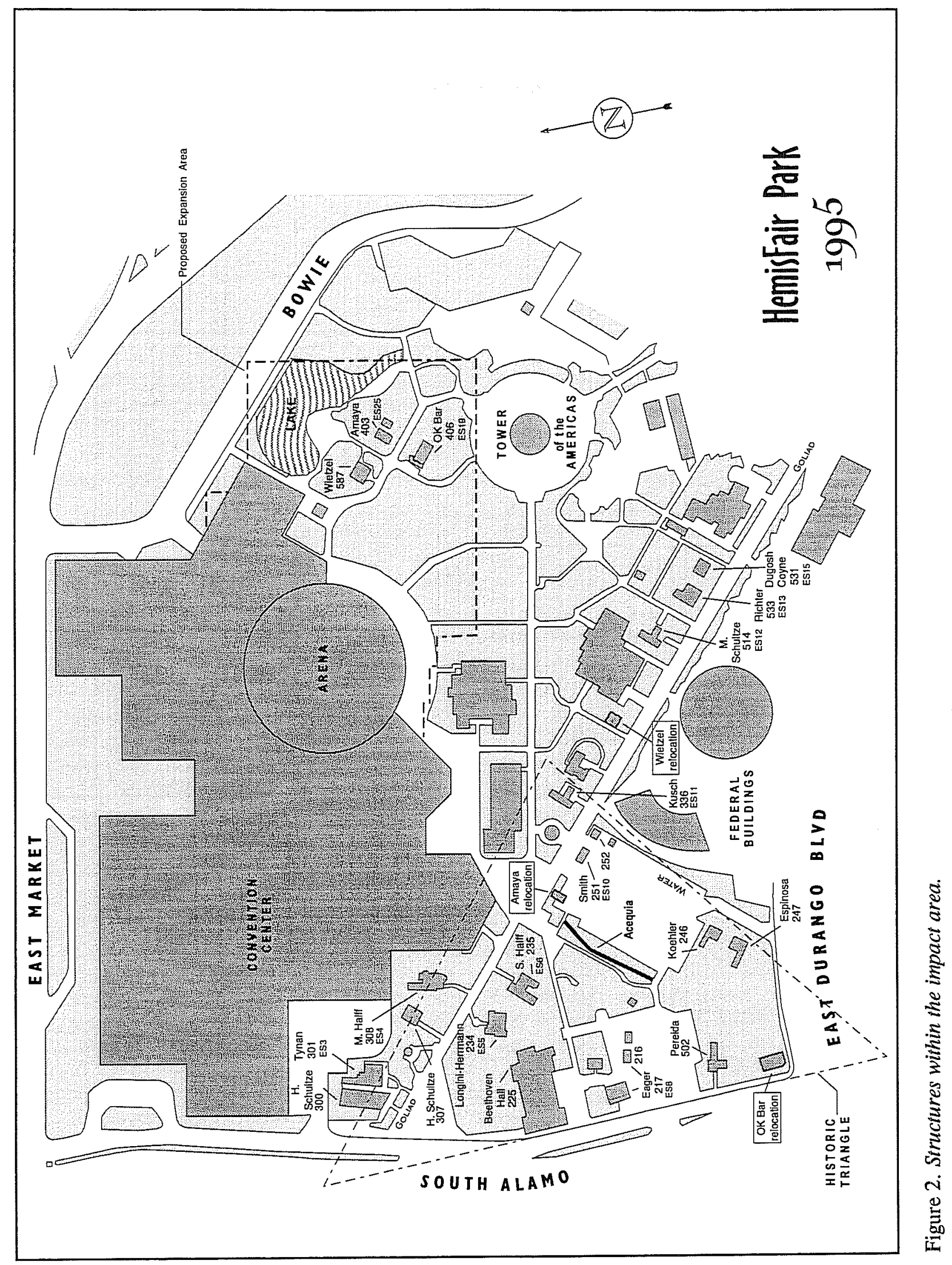




\section{Part I: Historical Background}

\section{The Native American Inhabitants}

The first inhabitants in the project area were prehistoric Native Americans. We will probably never know what these early peoples called themselves or the lands they occupied. Archaeological data is our main, and sometimes only, source of information about prehistoric people and events. Accordingly, one way archaeologists identify and differentiate ancient cultural groups is to note stylistic differences in the artifacts they left behind. Current evidence suggests that prehistoric groups may have occupied this land as far back as 11,000 to 12,000 years ago.

The Historic period is generally marked by the arrival of the Spanish and other Europeans to this hemisphere. When the first Europeans arrived, hundreds of small, independent bands of hunting and gathering peoples occupied the dry, brushy area of South Texas (Campbell and Campbell 1985:1). Campbell and Campbell suggest these bands may have been affiliated with as many as six major language groups, including Coahuiltecan. The first eyewitness accounts of the San Antonio River describe a settlement of Coahuiltecans within the present city limits of San Antonio in 1691 (Campbell 1975:7). Known as the Payaya, these people ranged from the San Antonio River to the southwest for a distance of 50 miles (Campbell 1975:8). They called their San Antonio River settlement Yanaguana (Newcomb 1993:31). When Mission San Antonio de Valero was established in 1718, the Payaya were one of the first groups to enter the mission, and they continued to be the largest Indian group represented there. A smaller number of Payaya also entered Mission Concepción. By 1800 the South Texas hunting and gathering bands had all been either decimated or assimilated into Spanish society (Guderjan and Canty 1994:8).

\section{Early Spanish History}

Until the late seventeenth century, Spain had recognized the Rio Grande del Norte as the northern boundary of New Spain, separating their rich possessions from the tierra incognita in the vast interior of the continent. However, when the French established a fort on the Texas coast, Spanish claims to the unsettled lands were jeopardized. In February 1685, René Robert Cavelier, Sieur de La Salle, believing that Spain and France were still at war, landed a group of colonists on Matagorda Bay (Weddle 1996:86). Although La Salle's attempt soon failed, the mere threat of a French presence in the Gulf of Mexico spurred Spain into action. To protect its claim to the previously undesirable lands, Spain attempted to establish missions in the lands of the confederacy of the Caddoan Hasinai in deep East Texas. For a quarter of a century these efforts struggled and failed, were reestablished, then withdrawn with little visible success. One of the clerics who had accompanied the early expeditions, Father Antonio de San Buenaventura y Olivares, a guardian of the College of Santa Cruz de Querétaro, had a vision of establishing a mission in a rich valley that he had seen in 1709 (Chipman 1996:1145).

After Spanish interests were renewed by further French activity in 1713, Father Olivares recognized the opportunity to pursue his interest. He petitioned the new viceroy, the Marqués de Valero, Don Baltazar de Zuñiga, for more governmental support of the East Texas missions, and presented his own decade-old dream: a new mission in the valley of the San Antonio River. He arrived in Mexico City in late September 1716, bearing a letter from the new Guardian of the College of Querétaro, Fray Joseph Diez, and received an audience with the viceroy. He presented not only his own views of the richness of the province, but had carefully compiled the reports of all the other missionaries. "It is impossible to exaggerate the pleasant character, the beauty, and the fertility of the province of Tejas from the Rio Grande, 
where our missions begin to the new ones which the zeal of Your Excellency desires to establish" (Castañeda 1936:71). He spoke of the richness of the wild crops of flax, grapevines, and nuts, and of the availability of game. "So numerous are the deer that they appear as flocks of goats. The buffalo are many; so great is their abundance that they appear as large herds of cattle" (Castañeda 1936:71). He told of more than 50 Indian tribes and how "on numerous occasions" they had expressed a desire to become Christians. Father Olivares then presented his plan to establish a mission on the "San Antonio de Padua" (Letter from Olivares to the viceroy, November 20, 1716. Archivo General de la Nación, México, Provincias Internas [AGN], 181:127).

The viceroy gave his approval to all Father Olivares's requests and, on December 7, appointed Don Martín de Alarcón as governor of Texas and charged him with delivering aid to the East Texas missions, assisting Olivares in establishing his mission, and founding a presidio and villa in support of the new mission on the San Antonio River (Habig 1977:20). Fray Olivares returned to the College at Querétaro and selected two companions to accompany him on the new venture. But many factors delayed the departure, causing a great deal of strife between Olivares and Alarcon. Finally, a year and four months after the viceroy's orders, Alarcón's entrada was assembled and prepared to cross the Rio Grande. On April 9, 1718, his assemblage forded the Rio Grande at the Paso de Francia, six miles southeast of Guerrero, Coahulia, Mexico, near Mission San Juan Bautista (Weddle 1968:5).

\section{Founding of the Mission and Beginning the Acequia}

Because of the discord between the priest and the governor, the two refused to travel together. Alarcón and his party did not follow the earlier routes to the San Antonio valley, but attempted to find a new route; they were impeded by swollen rivers and heavy vegetation and did not arrive at the San Antonio River until April 25. Fray Olivares and his small escort did not leave the Rio Grande until April 18, and joined the larger party at the San Antonio River on May 1. Immediately upon Olivares's arrival, the governor granted him possession of the site, "in the name of His Majesty," for the founding of the new mission. Olivares, with the help of Brother Pedro Maleta and three Indians whom he had raised since birth, erected a temporary jacal and celebrated the "Holy Sacrifice of the Mass" to dedicate the founding of Mission San Antonio de Valero, so named in honor of the viceroy, the Marqués de Valero. This humble structure was constructed "near the first spring, half a league from a high ground and adjoining a small thicket of live oaks" (Hoffmann 1938:318). This was intended only as a temporary location until the Indians, for whom the mission was intended, returned from their seasonal rounds of hunting and gathering.

For his mission, Olivares required more land and a place where an acequia, or irrigation system, could easily draw water from the abundance of the springs. He had already selected an ideal location. On his first visit, with the Aguirre expedition in 1709, he had noted the numerous springs forming the head waters of the river (Figure 3) and knew that those waters could be easily tapped near the ford just below their confluence, the Paso de Tejas, on the road to the eastern missions. Fray Mezquí, another of the priests accompanying the expedition, noted that investigations shortly after their arrival had located an area on the ford of the San Antonio River, about one-half mile below the headwaters, where the "water rises to the top of the ground, and the entire work is a matter of using a plow" (Hoffmann 1938:317-318). This point is just below the juncture of the numerous springs that join Olmos Creek to form the San Antonio River in present-day Brackenridge Park.

When Mission San Antonio de Valero was moved is not known, but during the first year Fray Olivares suffered a fall from his horse and broke his leg; therefore, the move was probably delayed until he recovered in the spring of 1719 (Habig 1968:41). Since the acequia was initiated in January of that year, it would have been constructed to serve the intended new site, just to the south of its present location. This would mean that the Mission San Antonio de Valero acequia, later to be known as the Alamo Madre, was begun in 1719, and the mission site relocated some time later that year. In 1720 Fray Francisco Hildalgo succeeded Olivares when the latter retired because of advanced age and poor health (Chipman 1996:1143). 


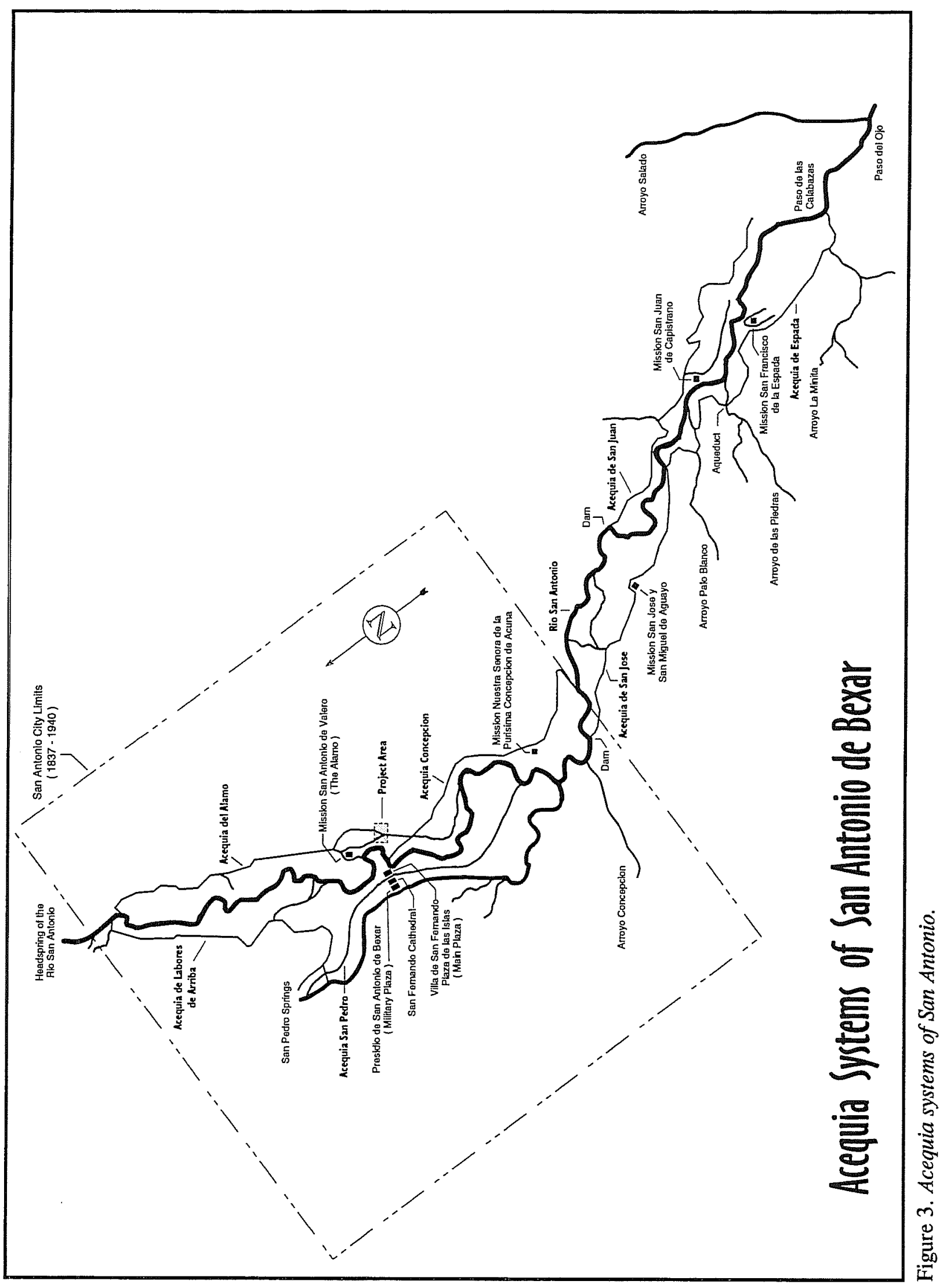


The acequia emanated from the point suggested by Fray Mezquia, just below the ford of the river, by means of a diversion dam constructed from the west bank of the river and extending into the stream to raise and direct the flow toward the eastern bank where the channel intake was located. The acequia then traced a sinuous path, between the river and the low hills to the east, toward the south-southwest to pass through the mission grounds to return to the river at the largest bend, creating a canal approximately 3.5 miles in length (Figure 3). Later additions to the channel, branching near the mission and irrigating additional labores, or farm lands, to the east and south, would extend the total length of the acequia to approximately 10 miles. The current study area lies within the branches of those later extensions.

On October 15, 1727, Fray Miguel Sevillano de Paredes visited the mission and reported the condition of the mission at that time. He noted that the clerics had established "a little fortification two gunshots [approximately 300 yards]" from its present location, but everything had been destroyed by a hurricane in 1724, at which time it was moved (de Paredes 1727). $\mathrm{He}$ also reported that the acequia was still one league (2.63 miles) away from the mission; the delay in completing the acequia resulted because "the entire project was an arduous one, since it was carried out solely by using crowbars" (de Paredes 1727). Paredes commends Fray José González, Hidalgo's assistant, for his dedication to the project. He further commented that the work had been repeatedly delayed by the need to protect the struggling mission from Apache attacks, requiring them to discontinue work on the acequia and fortify their quarters. Because of the importance of completing the acequia, work on the stone church had not begun, but they had selected the stone and were awaiting the arrival of a master craftsman (de Paredes 1727:35-38).

\section{Irrigation and Farming}

As soon as a mission was established, one of the first considerations was the establishing and planting of the fields. The missions were, by their very nature, remote and distant from the established centers of population and the long lines of supply necessitated that they must produce the goods to sustain themselves. Not only were crops necessary to allow the mission to become self-sufficient, they were critical in allowing the mission to continue to function and perform its duties to both the church and the crown. One such duty was training the neophytes in the principles of agriculture. From the Spanish viewpoint, the Indians were to be molded into a model of European culture, requiring that they be drawn away from the nomadic hunting-and-gathering lifestyle. The Spanish recognized that much of these new lands could be farmed to produce abundant crops, but only with irrigation to supplement the meager rainfall (Chipman 1992:5-6).

The locations and sizes of the agricultural tracts of the mission were determined solely by the route of the acequia, which in turn was dictated by the contours of the land. In the case of the acequia for Mission San Antonio de Valero, this meant that the land irrigated would be between the acequia and the San Antonio River, to which the acequia returned.

Canal irrigation is a system of transporting water by gravity from a source through artificially constructed open canals to agricultural fields. An acequia is often thought of as merely a ditch to convey water from one point to another. While this is essentially true, its operation is much more complex and requires a myriad of components and controls. The first is a device to contain and direct the water into the channel; this is usually accomplished by means of a diversion dam. A diversion dam, in contrast to a storage dam, does not impound water, but merely raises the water so it will flow into an irrigation channel. Excess water is allowed to flow over the top of the dam without the use of floodgates or spillways. The principal channel is generally called the acequia madre, or mother ditch. This is not a title for a specific acequia, but the primary ditch of any system. Near the point where water is directed from the stream channel, a head gate is installed to control the flow into the madre. At the point where the flow is needed to irrigate the fields, distribution canals are constructed from the main channel with the flow controlled by sluice gates. Often desagues, or discharge channels, are required to control flooding and excess flow. If the channel must pass over a obstacle, such as a stream or another acequia, an elevated structure, an aqueduct, is constructed to carry the flow over the obstruction. This can often be as simple as a canoa, a hollowed-out log, or as 
complex as a massive stone structure such as the one still functioning near Mission Espada. Once the water reaches the field, it is distributed into the various agricultural plots by shallow furrows.

One of the earliest recorded directives concerning the control of community irrigation is found in the Code of Hammurabi, ca.1700 B.C. It contains three basic principles of water usage: proportional distribution, individual responsibility, and collective responsibility. Summarized, the code states that the cultivator should receive water in proportion to the amount of land owned, but has a responsibility to share the water and maintain his section of the canal, and the entire system in the responsibility of all cultivators collectively (Encyclopedia Americana 1957(13):666-668). These same basic principles were later adapted into Spanish laws and carried to the New World. Acequia usage in New Mexico today is governed by these the basic procedures of acequia management and remain essentially unchanged (Crawford 1988). An example of these directives is contained in orders issued by the local government in 1784 concerning the management of the Upper Labor acequia in San Antonio. They ordered that "beginning on the twelfth day of January and thereafter, the work of reinforcing the enclosures be undertaken in common, and that the rest of the year each individual partner is to take care to repair the water gates and whatever deterioration may occur in the part that belongs to him" (Bexar Archive Translations [BAT], Bexar County Archives, Bexar County Courthouse, San Antonio, 1784). They further ordained that after the third of February, the cleaning and repairs on the main ditch were to begin "so as to facilitate irrigation to prepare the land for sowing early corn, cane fields, and gardens" (BAT, 1784). These dates were selected to insure completion of all necessary maintenance and field preparation immediately after the date of the last anticipated freeze, now March 4, allowing for the earliest possible harvest and permitting two crops per growing season (Enge and Whiteford 1989:43).

The present farming practices of the Tehuacán Valley of Mexico reflect the nature of irrigation agriculture as it has been practiced for centuries, first under Spanish and then under the Mexican governments (Enge and Whiteford 1989:43) The conditions of that semi-arid land give us insight into the nature of the methods utilized in the fields of early San Antonio. In both cases the soils are a result of the decomposition of the native limestone, resulting in an excess of calcium salts and carbonates, creating an extremely alkaline condition. Furthermore, climatic conditions allow for double cropping for those who have access to a year-round supply of water. Field preparation begins in early spring with an initial deep plowing and subsequent soaking of the soil, allowing adequate water to reduce the salinity and alkalinity $(\mathrm{pH})$ to an acceptable level. Six to eight days after the initial soaking, the fields are harrowed to break up large clumps, smooth the surface, and distribute the moist soil.

Prior to planting, the farmers inspect and repair the entire infrastructure of the irrigation system (canals, dams, and gates). The week following harrowing, the field is plowed into deep furrows for immediate planting. Once planting has been completed, the initial irrigation (primer riego) is applied. Depending upon the volume of the water the system can supply, the irrigation lasts up to 12 hours (Enge and Whiteford 1989:44-45). The standard dula, or allowance, specified in the deed records of San Antonio is onehalf day of water for each tract. In fact, the standard grant actually specifies the amount of water allowed "con su tierra correspediente [with the corresponding lands]" (Land Grants and Sales [LGS], Bexar County Archives, Bexar County Courthouse, San Antonio). This same system of water allocation can be observed today in the fields of the Espada Ditch Company, the only Colonial-period acequia system still in operation.

\section{The Isleños and More Missions}

Four days after the founding of the Mission San Antonio de Valero, the Presidio San Antonio de Béxar was established at a site near San Pedro Springs. The families that accompanied the soldiers, clustered near the presidio in humble huts, would become the first civilians in the settlement that would later become the most important outpost in Spanish Texas (Chipman 1992:117).

The small community associated with the Presidio slowly continued to grow, if not prosper. At the end of the first decade of its existence, Béxar had grown to about 25 civilian households and a total population of approximately 300 (de la Teja 1995:18). But the 
remote frontier settlement was about to experience an influx of immigration that was to have a major impact upon its social structure.

On March 9, 1731, the community was augmented by the arrival of 56 individuals from the Canary Islands. Their arrival was the culmination of a recommendation in 1719 by the Council of the Indies that 200 families be recruited from the Canary Islands and the kingdom of Galicia in Spain to form a series of civilian settlements along the frontier. Initially the king refused to accept the council's advice, favoring settlement from the families already established in New Spain to reduce cost. However, a few years later the idea was reevaluated and seen as a way of reducing the need for expensive presidial guards by the substitution of civilian settlers. It was believed that the new settlers would be obliged to defend their lives and property out of self-interest, reducing costs (Chipman 1992:135). The program was delayed by many factors within the Spanish bureaucracy and the physical difficulties of the relocation, but the arrival of the small group of exhausted Isleños was a result of that plan.

The king had offered royal passage to the frontier, free land, and maintenance for one year; an irresistible proposal to many of the families trapped in poverty on their native islands. As an additional incentive for the settlers, the king awarded the rank of hidalgo to those settling the new frontier. The title, derived from "hijos de algos" (literally "sons of something") denoted the lowest rank of Spanish nobility. The honor was bestowed to instill a sense of dignity in order to compensate for the hard life the settlers were to face; however, the recipients perceived it as removing them from the nonaristocratic working class, an unrealistic attitude for farmers on the extreme fringe of the Spanish empire. They were also invested with the authority to establish the first recognized civil administration in the new land, authority which gave them full control of the town's cabildo, or city council. The original settlers had constructed simple structures and farmed small plots, but had no legal title to the land. Since the new arrivals were the rightfully designated civil government, the old settlers were dispossessed of the lands they had been cultivating (Poyo and Hinojosa 1991:43-45).
This shifting of land ownership and utilization was restricted to the west bank of the river. Mission San Antonio de Valero still retained full title to all of its lands, with only one restriction to Valero's full use of water and lands on the east. Mission San José y San Miguel de Aguayo had been founded in February 1720, by Fray Antonio Margil de Jesus. Although the location of the site of Mission San Jose is not recorded, Fray Espinosa reported that it was located on the east side of the river, as is shown on a map drawn by the Marqués de Aguayo shortly after its founding (Habig 1968:29-30). The map does show the mission situated near the confluence of San Pedro Creek and the San Antonio River. The mission was moved to a new site on the west bank of the river prior to 1727 , still well south of the lands of Mission Valero.

In 1724 Brigadier Pedro de Rivera y Villalon was dispatched by the viceroy to inspect and evaluate the frontier defenses of New Spain. The tour lasted until June 1728, and covered over 8,000 miles. Among his recommendations was the reduction of the East Texas garrisons and the relocation of the three Querétaran missions to new sites on the Colorado River, near present-day Austin. Viceroy Juan de Acuña, the Marqués de Casafuerte, acting on the recommendations, reduced the presidios and moved the missions in July 1730. That location was not acceptable to Fray Paredes, the guardian of the college, and the missions were moved to the San Antonio River basin on March 5, 1731, only four days prior to the arrival of the Isleños. Nuestra Señora de la Purisima Concepción de los Hainai became Nuestra Señora de la Purisima Concepción de Acuña, and was located between San Antonio de Valero and the new site of San José y San Miguel. San José de los Nazonis, now San Juan Capistrano, and San Francisco de los Neches, now San Francisco de Espada, were assigned lands farther to the south.

\section{The Adaesaños}

In 1756 the major powers of Europe became embroiled in what was to become known as the Seven Years' War, the first war to involve the entire continent. The ultimate results of that conflict had major impacts throughout Europe, as well as in Asia 
and North America. When the war ended with the Treaty of Paris on February 10, 1763, Great Britain emerged as the undisputed leader in overseas colonial power. Great Britain gained control of France's empire in India and almost all the French possessions in North America. Spain relinquished Florida to the English, but was compensated, in a secret treaty, with the French territories to the west. Thus the major threat to the Spanish frontier shifted from the French to the British and the increasingly hostile border tribes. Texas ceased to be the outpost against the French threat, the purpose it had held since its founding. Spain redeployed its defenses to fortify Louisiana and California and strengthen the frontier against the Indians (Bolton 1970[1915]:102-104).

King Carlos III appointed the Marqués de Rubí, Cayetano María Pignatelli Rubí Corbera y Saint Clement, the formidable task of investigating and evaluating the defenses of this vast borderland. Rubr began his inspection in the far northwest in March 1766 and reported his findings to the king in April 1768. Rubí found little good to report about the East Texas missions and presidios. The garrisons were in ruins and undermanned, and the missions had been unable to attract or retain Indian populations ( $\mathrm{La}$ Fora 1958:160). The marqués determined that Spain was spread too thinly over too much territory. He recommended a cordon of 15 strongholds spaced at regular intervals between $\mathrm{La}$ Bahía del Espirito Santo at Goliad to the Gulf of California, with Bexar and Santa Fé as outposts (Bolton 1905:67-69). These recommendations resulted in a royal order on September 10,1772, to implement Rubr's new plan of defense. The order reached the governor, the Baron de Ripperdá, in May of the following year. Upon his arrival in East Texas, he encountered a population of more than 500 protesting citizens, whom he expelled. He ordered the evacuation to begin in five days, but faced with protest, he allowed extra time and the exodus began on March 25,1774, from the East Texas community of Los Adaes.

Forced to abandon their ripening crops and much of their livestock, the refugees suffered many hardships on the journey, and arrived in San Antonio on September 26 (Bolton 1970[1915]:113-115). Upon their arrival, Ripperdá ordered them to select any lands they desired, providing there was no interference with the lands already assigned to the settlers or Indians. He also granted them permission to construct an acequia, at their own expense, from the San Antonio River. They immediately lodged a protest, stating that there was not enough land for settlement without encroaching upon the rights of others, and that their poverty did not allow them to construct the proposed acequia. Therefore they requested permission to return to the eastern frontier. The request to return was refused, but in 1774, they were allowed to establish a new settlement, Nuestra Señora del Pilar de Bucareli, on the Trinity River in Madison County (Bolton 1905:90-106). While the majority of the refugees did relocate to Bucareli, some of them remained in San Antonio, adding a new elementthe Adaesanos - to the community. Some 60 Adaesaños settlers remained in Béxar, bringing the total population to 1,474 (de la Teja 1995:21).

\section{The Need for Land}

In its remoteness, San Antonio de Béxar was totally dependent upon subsistence agriculture. Each town lot included small gardens to produce a portion of each family's needs. Those fortunate enough to own tracts having access to irrigation produced the bulk of the crops to feed both the presidio and the villa. The missions, with their vast farms, were able to grow enough to be generally self-sustaining. The remaining land was used for grazing cattle, sheep, and swine. Livestock was allowed to range freely on those lands designated as public pasture surrounding the town lots and public-use areas. The unrestricted animals forced farmers to fence agricultural fields.

As the population grew, the need for land with access to water became an increasing problem. The Isleños, with their control of the civic government, were in a position to ward off efforts by new military and civilian settlers to acquire farmland. The only watered tracts available for the population, other than the mission lands, were those created by the San Pedro acequia south of the villa. In an effort to alleviate the shortage of land, the Nuestra Señora de los Dolores (Our Lady of Sorrows) Acequia was created. This system emanated from the same springs that fed the river, curved around the hills near San Pedro Springs and returned to San Pedro Creek, supplementing the creek flow with its surplus. Begun in 1776 and 
completed two years later, this created 26 long, narrow tracts between the acequia and the river above the villa-the Upper Labores. However, since this project was created by those individuals who could share the expense of its construction, the land was acquired by the more affluent families, generally the descendants of the Canary Islanders (de la Teja 1995:80-83).

Even with well-irrigated land, production in this often harsh environment was difficult. Throughout the period of 1700 to 1850 , the climate was entirely different from today's. The extremes of temperature found in the historical records has been ascribed to a period of extreme cooling, termed the "Little Ice Age." Although the major cold phase ended by the mid-1700s, the severe winters and cool, moist summers continued (Weber 1992:10). This diverse nature of the climate was borne out by the growing season of 1785 and 1786 . The year began unusually dry, but some relief was brought by light showers in June; however, July saw drought and searing heat. Even irrigation from the acequias did little to alleviate the effect of the intense heat; the resultant harvest was reduced to a tenth of normal. The price of grain jumped to an unheard of 4.5 pesos per fanega, driving the citizens to eat "burdock roots and wild sweet potatoes" (BAT, Cabello 1785). The drought continued into the planting season of 1786 , and the farmers were hesitant to plant what little seed they had stored. The officials offered appeals for "divine mercy" and "public processions of penitence to appease the wrath of the Lord" (BAT, Cabello 1785). The fields were well irrigated to assist the germination of the crop, which met with some success, but in April a killing freeze destroyed the tender seedlings. The farmers "fell into total despair," but at the insistence of the governor, replanted their fields. Fortunately, June brought "copious and abundant rain" which resulted in an abundant harvest (BAT, Cabello 1786).

\section{Secularization}

Since the Upper Labores failed to solve the landrelated problems, citizens began to pressure for use of the under-utilized property of Mission Valero. By the last two decades of the eighteenth century, the missions were past their florescence and were in decline. The expulsion of the Jesuits from the New World in 1767 created a shortage of priests for the missionary efforts. In 1772 the four Querétaran missions of San Antonio were transferred to the College of Zacatecas. Fray Morfi reported that the population at San Antonio de Valero had dropped to the point that there were hardly enough Indians to tend the fields. The Adaesaños, who had settled near the mission, requested that the unused land be distributed among them, for they were without even a small plot of land upon which to raise their crops (Chabot 1932:60).

In 1790 the College of Zacatecas dispatched Fray Manuel Silva, commissary and prefect of missions, to evaluate the state of their efforts among the Indians. He recommended that San Antonio de Valero be secularized, and that the other four missions be reduced to only two. On January 9,1793 , the viceroy issued a decree implementing the recommendations, and Governor Manuel Muñoz published a proclamation, on February 23, putting the decree into effect. On April 12, the farmlands of Mission Valero were surveyed and plots given to the 14 family heads and unmarried adults of the mission. For their efforts the surveyor and his assistants, Pedro Huizar and Vincente Amador, were awarded similar tracts (Habig 1968:66-67). The plots (Figure 4) awarded to the Indians were in the area which became known as the labor de abajo, the lower farm (Bexar County Archives [BCA], Spanish Archives, 2:60). This area is now recognized as the King William Historic District.

In October 1793, the Adaesaños finally received the land for which they had been petitioning. Forty-five "converted heads of families" (de la Teja 1995:86-87) and others were granted land in the labor de arriba, the upper farm, which lay along the river north of the mission. The remaining lands, the labors de afuera, the outer farm, were granted to nine other Spanish residents of the mission and two of the townsmen (see Figure 4). Despite the long tenure of the mission, several of the tracts had not even been cleared for planting (BCA, SA, 3:305-315; de la Teja 1995: 86-87). The study area comprises the heart of these lands; the Adaesaños who received property in the HemisFair area are discussed in Part II. 


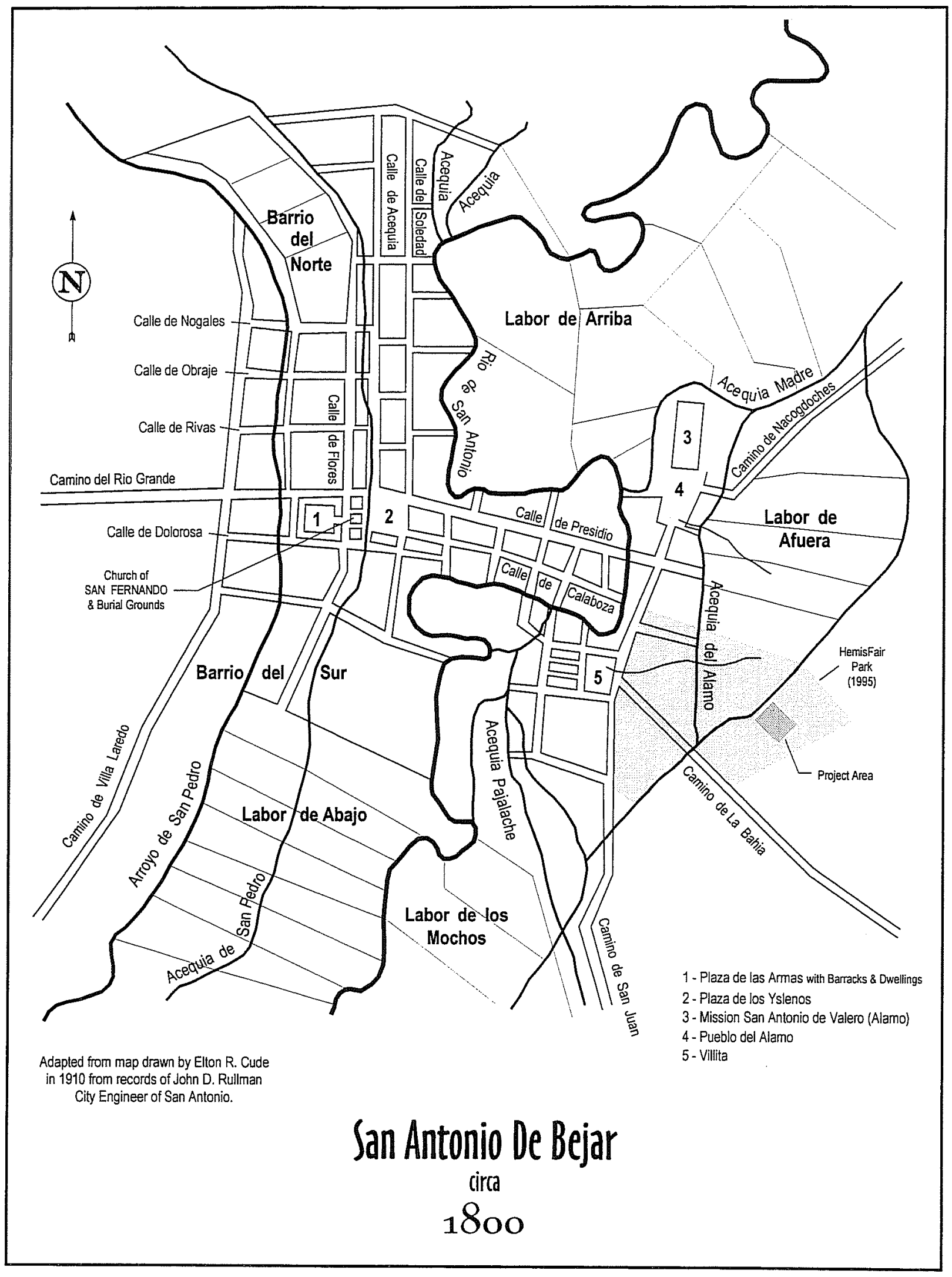

Figure 4. Land divisions in San Antonio, circa 1800. 
In December 1802, the presidio garrison at Bexar was augmented by the Compania Volante de San Carlos del Alamo de Parras, the Light Cavalry Company, from the town of Alamo de Parras, Coahuila. The governor, Nemesio Salcedo, assigned them quarters in the now-abandoned Mission San Antonio de Valero. It was from this occupation that the old mission received its more familiar name, Alamo. In 1805 the first hospital was established there to care for the number of patients "which the change of climate has caused in the troops from other parts of the country" (Nixon 1936:16). The families of the men stationed at the new garrison began establishing homes on the high bluff overlooking the river just to the south of the old church. Originally referred to as Pueblo de Valero, it soon became generally known as La Villita, or the "little village." Because of the increased traffic between the villa and the new garrison, on July 7,1803 , the citizens were directed to contribute their labor and carts of stone "for the construction of a bridge which the governor has decided to build to improve and facilitate communication with the pueblo of San Antonio de Valero" (BAT, Cabildo 1803). This replaced a crude wooden structure that had previously been the only link with the villa.

The major reason for this increase in military might on the Texas frontier was the unsettled conditions arising from the rumored purchase of the Louisiana Territory by the United States. When this became a reality, the major threat to Spanish Texas immediately shifted from the French to the Americans. It also produced a wave of immigration from that territory of settlers wishing to remain under the Spanish flag. Among these refuges was Joseph (José) de la Baume (Baum), who is discussed further in Part II.

\section{Political Unrest and Revolution}

In 1808 the powerful armies of Napoleon Bonaparte were sweeping across Europe, crushing many of the old monarchies. The Spanish king, Charles IV, abdicated in favor of his son, Ferdinand VII. However, Napoleon moved his army into Spain and placed his brother, Joseph, on the throne. This attempt to seize total control created a popular uprising and the formation of guerrilla forces who, joined by the English, drove France from the peninsula five years later.

During this period of unrest, the seeds of revolution took root in Mexico, not in the capital, but in a remote mining district. Fray Miguel Hidalgo y Costilla, at the head of an army of Indians, mestizos, and a few Creoles, declared independence from Spain on September 16, 1810. In January of the following year, the revolution spread to San Antonio. Juan Bautista Casas, a retired colonel, backed by the presidential garrison, placed himself as the head of the government and declared for independence with Hidalgo. His despotic and disorderly administration was overthrown on March 2, and he surrendered to the opposing forces. Casas was sent to Mexico, tried, and executed; his head was packed in salt and returned to San Antonio for display in the plaza as a warning to other rebels (Chipman 1992:233). Fray Hidalgo's army was routed the same month that Casas took power, and Hidalgo's execution followed in August of the same year (Faulk 1964:134).

But the rising wave of independence did not die with Hidalgo, and made Texas appear ripe for America's filibustering ambitions. In August 1812, José Bernardo Maximiliano Gutiérrez de Lara, a follower of Hidalgo, united with Augustus W. Magee and crossed the Sabine River with 130 men and captured Nacogdoches from the Spanish. Recruiting Mexican, Indian, and American supporters, they occupied La Bahía on November 7, where they were placed under siege by Governor Manuel Salcedo. Upon the death of Magee on February 6, 1813, Samuel Kemper assumed command. The following month, Kemper, with about 800 men, marched toward San Antonio. The city surrendered unconditionally on April 1, and three days later 14 loyalist officers, including Salcedo, were executed. The following August 18, General Joaquín de Arredondo, with some 4,000 men, met and routed the insurgents south of the Medina River. Arredondo's retribution was swift and bloody: in addition to the 600 slain on the field of battle, he imprisoned most of the population of the city. In all, 327 rebels were executed in Bexar alone. The retaliation left the town a shambles, the property of the citizens confiscated, and the majority of the men either dead or having fled the country (Fehrenbach 1983:125-126). 
This depletion of the manpower and resources of the province was to have a far-reaching effect that would influence both the political course of the government and the economy for over two decades. The most immediate ramification was the basic agricultural practices upon which the area was entirely dependent. Without the male population, no labor was available to maintain the acequia systems and plant the crops on which this remote frontier depended. This resulted in extreme hardships and food shortages for both the citizens and the military. It also intensified the everpresent problem of harassment from the Indians. Without men to guard the cattle and escort the workers into the field, Indian attacks became bolder and more frequent. The problem is graphically clear in a petition by citizens to the town council for assistance. Don Vincente Gortari calls attention to

the extreme poverty of the people; the constant burdens to which the small number of the citizens which the town has are exposed; and the urgency in which they find themselves today of coming to the aid of their enterprises; cleaning of ditches and other task as imperative as they are indispensable for obtaining the harvest upon which the subsistence of the public depends [City Council Minutes (CCM), Office of the City Clerk, City Hall, San Antonio, Spanish Minute Book [SMB] 1:54].

In response to the appeal for help, the governor temporarily discharged some of the troops of the garrison to assist the farmers in planting and harvesting the crop so that the yield would be sufficient to feed both the populace and the military. On the basis of this added labor force, the farmers used their remaining stores of seed and increased their plantings and offered up more of their stock. However, in April of the following year, the height of the planting season, General Arredondo recalled the troops to duty. This resulted in a special session of the council in which they drafted an impassioned plea to the governor protesting the recall. They complained that after the defeat of the insurgents the general had taken away their firearms, leaving them defenseless against the attacks of the Indians. They further noted that "two thirds of the citizens have departed and located their homes in other less unhappy districts" and that where the area had been "abundant in its products and harvest, it can today consider itself among the most unfortunate and poverty stricken, for the lack which it suffers in its agriculture because of the workers that have abandoned it" (CCM, SMB 1). They appealed to the governor for relief for "besides being without clothing, as well as weighted down by miseries and without help, they are barefooted" (CCM, SMB 1:98-108).

As the condition on the frontier was disastrous, an inspector for the viceroy could see no other option to repopulate the villa than to restore all confiscated properties to "the original and legitimate owners" to encourage their return (Padilla 1919:64). In December 1820 , a bankrupt lead miner from Missouri, Moses Austin, arrived in San Antonio with a partial solution to the lack of settlers in Texas: a request for authority to begin a colony of AngloAmerican settlers. His petition was granted on January 17,1821 , allowing him the right to settle 300 families on 200,000 acres in the lower Brazos valley. After his death, in June of that year, his son, Stephen Fuller Austin, began work to carry the project forward into reality.

However, events in Mexico were moving toward a dynamic change in Spanish control. The revolutionists continued their struggle on several fronts until Vicente Guerrero joined with Agustín de Iturbide, a mestizo officer, and reached an agreement of purpose-the Plan of Iguala - that turned the tide for independence. Iturbide entered the capital on September 27, 1821, and Mexico became an independent nation. When Austin arrived with his first colonists, in December of that year, he found that the new government did not recognize his grant from the old government. Austin immediately rushed to Mexico City and succeeded in persuading the legislature to complete a law effectively re-establishing the empresario program. The law was annulled when Iturbide abdicated, but again Austin induced officials to grant him a new contract allowing him to introduce 300 families into Texas (Webb 1952:I:80-82). Other empresarios soon followed, producing a steady flow of immigrants, primarily into the rich bottom lands in the upper and central coastal plains.

This influx of new settlers had little effect on the population of San Antonio, which now numbered only 1,625. The new Federal Constitution of Mexico, adopted in January 1824, merged the provinces of Texas and Coahuila into one state with its capital in 
Saltillo, causing San Antonio to suffer a loss of prestige. However, the following year Texas became a separate department with San Antonio de Bexar as the capital.

Mexican independence was a reality, but the transition did not bring tranquillity. Less than a year after Iturbide's victory over the Spanish royalists, he instigated a revolt and proclaimed himself Emperor Augustine I of Mexico. He held power less than a year before being overthrown and exiled. The monarchy was replaced by the Federal Constitution of 1824, influenced by the United States Constitution and European liberalism. Yet, the conflict between the federalists and centralists continued to fracture the government, aggravated by foreign intervention. In 1829 Spain invaded in an attempt to regain the country, only to be repelled at Tampico by a young Mexican officer, Antonio López de Santa Anna Pérez de Lebrón.

The heavy-handed policies of the United States minister to Mexico, Joel Poinsett, infuriated the Mexican government and aroused new hatred and fear of the North Americans. Anastasio Bustamante, a reactionary tyrant, seized power, and placed Texas under the control of Manuel Mier y Terán, an avowed critic of North American colonization. Terán moved to garrison Texas with troops, an action which angered and threatened the new colonists. In May 1832, Captain Juan Bradburn declared 10 leagues of the coast under martial law and arrested several citizens, including a young firebrand named William B. Travis. Rebellion broke out among the Anglo-Texans, who moved to attack Bradburn's headquarters at Anáhuac and captured the fort at Velasco at the mouth of the Brazos River, rallying with cries for the return of the Constitution of 1824 and the hero of Tampico, Santa Anna. Total rebellion was averted only by the diplomatic effort of Austin and the continuing chaos within the government (Fehrenbach 1983:174-180). In June 1834, President Farias was ousted and Santa Anna took control of the government.

By 1835 Santa Anna was fully entrenched in power. The state of Zacatecas rose in revolution and was brutally suppressed by Santa Anna, using methods he had learned as a lieutenant with Arredondo. In April he dispatched an army under the command of his brother-in-law, General Martín Perfecto de Cós, to put down a minor civil war in Coahuila. Cós then moved north to reinforce the garrisons in Texas. Santa Anna officially revoked the liberal Constitution of 1824 shortly thereafter. In September, Austin returned to Texas from 18 months of prison in Mexico, now convinced that the differences between the Texas colony and the new government were irreconcilable. The stage was set for full revolution.

The revolt began on October 1,1835 , with shots fired at Gonzales, and soon the "Army of the People" under Austin's command marched to San Antonio to place General Cós under siege. Cós prepared for battle by employing his troops to fortify defensive positions about the villa. He constructed strong cannon positions around the plazas and began to convert the old Mission Valero into a fortification. Despite victories achieved in skirmishes, such as the battle of Concepción and the grass fight, the siege stagnated and almost dissolved until December 4 , when a group of volunteers under Colonel Ben Milam rallied to assault the city. They took up a position at the Molino Blanco, the old mill on the first return channel of the Upper Labor acequia, and attacked the city from the north in house-to-house combat. General Cós capitulated to the Texans on December 10, and was paroled to withdraw his troops south of the Rio Grande. The humiliating defeat of his brother-in-law angered Santa Anna into a fury that drove him and his army into Texas with a speed that caught his enemy by surprise. When the Mexican army arrived on February 23, 1836, the Texans were forced into a hurried withdrawal behind the wall of the makeshift fortress of the Alamo. After 13 days of siege, the Alamo fell in a concentrated assault on the morning of March 6, 1836, and Santa Anna achieved what was to prove to be a Pyrrhic victory. After sweeping across Texas and driving Houston's army to the edge of the territory, he was caught unprepared by the Texans at San Jacinto. There he was defeated and captured in a battle that lasted less than an hour. From this victory, the Republic of Texas was forged.

\section{Under the Republic of Texas}

On September 23,1837 , the new city council of San Antonio, now Bexar County, convened and elected John W. Smith as mayor. Smith, known locally as $E l$ 
Colorado for his flaming red beard, was a participant in the siege of Bexar and the battles of the Alamo and San Jacinto. In 1830 he married Maria de Jesús Delgado Curbelo, a descendant of the Canary Islanders. The other council members were all natives of Bexar (Scanlan 1996:1104-1105; CCM A:1-6). The council agreed that the city would observe all ordinances of the prior government until new ones were passed.

The need for improved sanitation was soon recognized and, on March 13, 1838, the council prohibited the slaughtering of beeves within the city, restricting such activity to "the other side of the creek or ditch west of the town, and on the east beyond the ditch of the Alamo" (CCM A:1-6). The same session ordained that the regulations requiring the property owners along the acequia to maintain their portions were still in effect "under the penalty of being fined in such sum as the council may deem necessary to carry this object into effect" (CCM A:1-6). The ordinance was adopted and ordered to be published, however in Spanish only.

Although Texas considered itself a republic, Mexico refused to recognize its independence and a formal state of war continued, but unsettled conditions within Mexico prevented any overt action until 1842 . On March 5, General Rafael Vásquez, with 700 Mexican soldiers, arrived in San Antonio. The defending Texan force was too small to hold the town and withdrew to Walnut Springs (now Seguin). Vásquez raised the Mexican flag over the town and declared Texas still under Mexican law; his show of force completed, he withdrew two days later beyond the Rio Grande. The mayor of San Antonio at that time was Juan Nepomuceno Seguín, one of the most noted and respected Tejanos of the Revolution and Republic periods. He served in Austin's army, under Travis at the Alamo, and commanded the only Tejano unit to fight at the battle of San Jacinto. As the only Mexican Texan in the senate of the republic, he served for three terms. He was elected mayor in 1840 , even though he was suspected of having betrayed the failed Santa Fe expedition (de la Teja 1996:966-967).

The reported friendship between Vásquez and Seguin increased suspicions concerning the latter's loyalty, forcing him to resign on April 18 and to flee to Mexico with his family (CCM, A:73). John Smith was again chosen as mayor, and this time a sworn deposition to support the constitution of the Republic was required (CCM, A:79). In September 1842, General Adrian Woll, a French soldier of fortune and personal friend of Santa Anna, returned with a larger force and again captured San Antonio. This time the Texans offered resistance and Woll was forced to withdraw. Nevertheless, Woll found the District Court in session and took with him 67 prisoners, including all the Anglo males in the town (Gunn 1996:686). This uneasy state of affairs was finally settled with a truce with Mexico, which established an armistice, but not peace, on June 14, 1843. Despite the troubled times, San Antonio experienced a period of growth, with immigrants from both the United States and Europe.

\section{Late-nineteenth Century}

The Texas republic had always expressed a desire to join the United States, and through its president, Sam Houston, had immediately asked for recognition, to be followed by annexation. While President Andrew Jackson favored annexation, he feared opposition from the Northerners against a new slave territory, and felt Texas statehood would probably lead to war with Mexico. His successor, Martin Van Buren, withheld his support for similar reasons. Thus the republic was forced to turn to Europe for recognition and financial support. Much of Europe, especially England, viewed Texas as a barrier to American expansion to the Pacific and as a lucrative market and ready source of cotton. When England and France readily extended recognition, President Tyler, eager to increase Southern power, persuaded Texas to apply again. Secretary of State Calhoun presented an annexation treaty to the senate in April 1844 (Current et al. 1979:366).

During early statehood, Texas experienced a population boom. Large numbers of immigrants came from the southern United States and Europe; much of San Antonio's growth was derived from the latter. As discussed above, land speculators who envisioned continued growth in the city's population eagerly purchased suertes and large tracts of undeveloped land. Large parcels were surveyed and divided into smaller lots. Costly improvements, such as house 
building, were not usually undertaken, for along with the chance for profits loomed the possibility of bankruptcy.

\section{The Project Area}

This element of risk meant that speculators seldom gambled more money than necessary. In theory the small lots were quickly resold and speculators made their profits while new lot owners had land on which to build. However, in reality this often was not the case. The Bexar County Deed Records ([BCDR], Bexar County Courthouse, San Antonio, Texas) show numerous transactions involving unimproved property that was bought, sold, and sometimes bought back again. In many cases it took years before someone finally developed a tract and actually lived on the property. Hence, this period of land speculation and the competition from other developing subdivisions delayed construction of permanent structures in an area that had already, in terms of development, fallen behind other sections of the growing city.

As large tracts were resurveyed and subdivided, land speculation continued even to the lot level. Eventually new owners and families began to buy the lots. Along with these latest buyers came the impetus for development and construction: the parcels were finally looked upon as a place to call home.

\section{San Antonio's Wards}

Effective July 19, 1856, San Antonio's corporate limits were divided into four wards covering 36 square miles (CCM, C:1-13). HemisFair Park falls within the confines of Ward 4. This ward included all the land east of the San Antonio River and south of Commerce Street. From there the ward extended to the city's eastern and southern limits. Property values assessed for the fourth ward in 1878 equaled $\$ 1,263,627$. This amounted to an increase of $\$ 211,559$ from 1876 . It also meant that about 16 percent of the city's total real estate value came from the fourth ward. Taken from the returns of an election held in November 1878, Table 1 shows voters by ward and ethnic affiliation.

Although San Antonio is usually considered in terms of its prominent Hispanic heritage, the city was also heavily influenced by its German population. Before the Civil War, South Texas had become the new home of approximately 30,000 German immigrants (Rybczyk 1992:61). In 1878 Wards 3 and 4 were dominated by Germans.

In addition, the fourth ward appeared to be the center for San Antonio's Polish population. The first Polish settlers arrived in the city on December 21,1854 . As with other European immigrants, while most were on their way to settle new communities elsewhere, some

Table 1. Voters in San Antonio Wards in 1878

\begin{tabular}{|c|c|c|c|c|c|c|c|c|c|c|}
\hline \multirow{2}{*}{$\begin{array}{l}\text { Nationality/ } \\
\text { Ethnicity }\end{array}$} & \multicolumn{2}{|c|}{ Ward 1} & \multicolumn{2}{|c|}{ Ward 2} & \multicolumn{2}{|c|}{ Ward 3} & \multicolumn{2}{|c|}{ Ward 4} & \multicolumn{2}{|c|}{ Total voters } \\
\hline & $\#$ & $\%$ & $\#$ & $\%$ & $\#$ & $\%$ & $\#$ & $\%$ & 等 & $\%$ \\
\hline German & 90 & 13.9 & 116 & 14.7 & 350 & 35.4 & 242 & 40.2 & 798 & $25 \%$ \\
\hline Mexican & 279 & 43.1 & 390 & 49.3 & 90 & 9.1 & 20 & 3.3 & 779 & 251 \\
\hline American & 177 & 27.3 & 150 & 19 & 250 & 25.3 & 176 & 29.2 & 753 & 243 \\
\hline African & 50 & 7.7 & 27 & 3.4 & 100 & 10.1 & 120 & 19.9 & 297 & 9.6 \\
\hline Irish & 12 & 1.9 & 53 & 6.7 & 170 & 17.2 & 20 & 3.3 & 255 & 82 \\
\hline French & 40 & 6.2 & 55 & 7 & 30 & 3 & 24 & 4 & 149 & 4.8 \\
\hline Polish & 0 & 0 & 0 & 0 & 0 & 0 & 70 & 11.6 & 70 \% & 2.3 \\
\hline Total voters & 648 & 100 & 791 & 100 & 990 & 100 & 672 & 100 & 3101 & 100 \\
\hline
\end{tabular}


decided to remain here. Located at 422 South Street, St. Michael's Polish Catholic Church was built in 1866 (Rybczyk 1992:68). In time, St. Michael's became the focal point of Polish life in San Antonio. One of the church's best known members was Ed Kotulla. In the 1890s this San Antonio-based rancher and merchant became known as the "Wool King of Texas." Kotulla remained a faithful member of the church and St. Albert's Polish Society until his death in 1907. St. Michael's Polish Catholic Church was one of many buildings torn down during the construction of HemisFair Plaza.

Ward 4 had 66 public streets and 238 building blocks. Of this total, only seven streets were partly macadamized in 1878. Of the 518 new buildings erected in the city that year, 99 were completed in the fourth ward (CD 1879-1882). The fact that some of these structures are still standing can be directly attributed to the concern and foresight of a few dedicated citizens and city leaders. In HemisFair Park, most of these properties front Goliad Street or are within the "Historic Triangle" in the southwest portion of the park. The Convention Center expansion is located in the northeast sector.

Circa 1890, San Antonio was subdivided into eight wards. The fourth ward was essentially split in half and became Wards 7 and 8 . In the HemisFair Park area, Water Street became the boundary line between the two wards. The seventh ward included land east of Water Street to the city limits, while the eighth ward ran west of Water Street to the San Antonio River (CD 1889-1890). Ward 7 included the area known as Beckville, which is discussed in detail in Part II.

\section{Ethnic and Socioeconomic Composition of San Antonio in 1878}

In 1878 San Antonio's population numbered over 21,000 . The ethnic diversity of these citizens is still seen today. Historic structures in HemisFair Park provide a glimpse of the city's multi-cultural past. Whether a large Victorian mansion or a one-room adobe home, the architecture proclaims the contributions of many different cultural groups. Although they are not conclusive, real estate ownership and property values are factors that may be used to help determine an ethnic group's socioeconomic status. A quick view of the 1878 population numbers, real estate values by nationality or ethnicity, and calculated per capita real estate values demonstrates a wide range in ownership and socioeconomic status (Table 2). Most of the property was owned by the German group and the American-British group, while African-Americans owned disproportionally less than all other groups.

\section{Into the Twentieth Century}

World events in the twentieth century, as with past centuries, had significant impact on the development of San Antonio and the lives of its citizens. The combined effects of war and depression created the socioeconomic setting which has shaped the modern city of San Antonio.

Table 2. Population, Total Real Estate Value, and Per Capita Real Estate by Nationality/Ethnicity in 1878

\begin{tabular}{||l|c|c|c||}
\hline \multicolumn{1}{|c|}{ Nationality/Ethnicity } & $\begin{array}{c}\text { Population } \\
\#\end{array}$ & $\begin{array}{c}\text { Real Estate } \\
\text { Value }\end{array}$ & $\begin{array}{c}\text { Per Capita } \\
\text { Real Estate Value }\end{array}$ \\
\hline German, Alsatian, Polish, Swiss & 7848 & $\$ 4,778,815$ & $\$ 609$ \\
\hline American, English, Irish & 7800 & $\$ 3,551,102$ & $\$ 455$ \\
\hline French & 310 & $\$ 534,890$ & $\$ 1,725$ \\
\hline Hispanic & 3470 & $\$ 519,418$ & $\$ 150$ \\
\hline Spanish, Italians, Hungarians & 67 & $\$ 111,950$ & $\$ 1,671$ \\
\hline African-American & 2178 & $\$ 46,650$ & $\$ 21$ \\
\hline
\end{tabular}


At the beginning of the twentieth century, the population of San Antonio was 53,321, an increase of over 15,000 from the census of 1890 . Yet the next 10 years would herald an even more dynamic period of growth, for during the next decade the city would almost double in population. The entire nation was growing and embracing the industrial and technological revolution, which was opening the fields of communication, transportation, and manufacturing. The telephone was a familiar fixture, radio was in its infancy, and the nation would soon see the development of the automobile and the introduction of the airplane.

In 1909 the federal government dispatched Lt. Benjamin Foulois to select an area at Fort Sam Houston for testing the newly acquired Wright Flyer. Foulois chose an open area near the Quadrangle, and assisted by nine enlisted men, he assembled and flew the Wright S. C. No. 1 on March 2, 1910, crashing it the following week. By early 1911, Foulois was joined by three additional pilots and a Curtiss Model D aircraft. One of the pilots, Lt. George Kelly, was killed in a crash near the camping area of the fort (Bilstein and Miller 1985:17-19). Kelly Field was named in his honor.

As San Antonio searched for its place in a changing society, the nation continued its struggle to maintain neutrality in a world torn apart by a war driven largely by the developments of modern technology. In April 1917, President Wilson was forced to ask Congress to declare a state of war (San Antonio Express-News [SAEN], 2 April 1917).

The city's place in the scheme of the war effort soon became apparent when the War Department announced in June that they planned to expend $\$ 7,000,000$ to equip San Antonio to serve as the training facility for some 60,000 troops (SAEN, 15 June 1917). These plans included the construction of a cantonment for 40,000 troops at Fort Sam Houston. By August 1917, the War Department was already searching for an area to be developed for aviation; the field selected was in the southeast near Berg's Mill and named Kelly No. 2, later renamed Brooks (SAEN 30 August 1917, 11 December 1917).

On September 9, 1921, the city was struck by a series of intense thunderstorms - with driving sheets of rain and deafening thunder-passing over the town one after the other, and continuing with no relief until mid-morning of the next day (Ellsworth 1923:8-10). The actual amount of rain varied considerably within the San Antonio River basin, but over eight inches was recorded within the downtown area, and over 17 inches reported in the upper Olmos Creek basin. "The crest of the flood was reached about 1:45 o'clock when the water was between 5 and 6 feet deep on Crockett Street . . . and was more than 8 feet deep at Houston and St. Mary's" (SAEN, 11 September 1921). The toll of the flood in San Antonio was 51 lives lost and property damage in excess of $\$ 3,000,000$. Throughout the state, the loss was 224 lives and more than $\$ 10,000,000$ (Ellsworth 1923:1).

Following the disaster, flood prevention bonds carried -by a majority of only 1,638 of a total of 15,904 ballots cast-and construction began on a containment dam in the Olmos basin. The dam has a maximum height of $90 \mathrm{ft}$ and a length of $1,940 \mathrm{ft}$, with an approach of $940 \mathrm{ft}$ on the Alamo Heights side, and $640 \mathrm{ft}$ on the southwestern or Laurel Heights side. It contains 90,000 cubic yards of concrete, 418,000 pounds of reinforcing steel, and has a storage capacity of $5,000,000,000$ gallons of water ( $S A E N, 28$ August 1926).

In February 1929, the city advertised for bids on a project for channelization of the downtown bend of the river, including a cut-off channel near the courthouse. By February 1, 1930, that work was completed ( $S A E N, 18$ March 1930). During the same period, architect Robert H. H. Hugman proposed to "divert all water of the river up to a certain level into the new flood channel and permit construction of walks and Spanish type architecture along the banks of the stream" but the city council deemed his plan impractical and too expensive (SAEN, 27 June 1929).

The growing impression of perpetual prosperity was evident in the shifting skyline of San Antonio. The beautiful Gothic-revival Medical Arts building towered above the historic old Alamo. The 21-story Milam Building, completed in 1928, was the first structure built entirely on a framework of reinforced concrete, and was also the first to be totally air conditioned. The Smith-Young Tower, constructed at a cost of $\$ 2,500,000$, was completed in June 1929 , immediately before the Majestic Theater and the 
Office Towers. The Nix Medical building was under construction on the river, as were the Alamo National Bank and the Southwestern Telephone building. The city was replete with expensive skyscrapers, reflecting the faith of investors in the economy. Then, on October 24, 1929-Black Thursday-the stock market began to fall; that day $12,894,650$ shares changed hands, for the most part at prices that shattered the hopes and dreams of their owners. A veteran observer commented that there was not a dollar to be loaned at the Wall Street Exchanges's "money post," and private lending rates had soared. But the experts in capital finance circles were quick to point out that this was the same pattern that had occurred exactly 22 years earlier, and a conference held by J. P. Morgan and other major investors insured that "sufficient money was said to have been made available to stop the break and turn the market upward" (SAEN, 26 October 1929). They expressed confidence that similar action would stem this latest panic (SAEN, 26 October 1929). However, this time there was no salvation and Tuesday, October 29, "was the most devastating day in the history of the New York stock market, and it may have been the most devastating day in the history of markets" (Galbraith 1972:116). The nation was thrown into the Great Depression.

With the election of Franklin D. Roosevelt and his "New Deal," federal money was directed toward public projects in an attempt to "put the nation back to work" (Galbraith 1972:9). San Antonio, like other cities, began to look to ways to apply for federal funds. Hugman's visionary plan for the river was again brought forth, and Work Projects Administration (WPA) funds were acquired. In midMarch 1939, ground-breaking ceremonies were held on the river, and the Riverwalk project was begun (SAEN, 19 March 1939). In late April of the following year, the week of the Fiesta de San Jacinto, the first section of the new river was opened to the public with soft-colored lights along the entire Big Bend, and a Sunday night concert by an orchestra playing in the outdoor theater (SAEN, 29 April 1940).

Mayor Maverick was also diligently pursuing his own pet project: the restoration of $\mathrm{La}$ Villita, the old Spanish village in the heart of downtown. He wished to restore the small settlement as a "symbol and monument to those simple people who had made possible the great city which had grown up around it"
(Henderson 1970:199). On Thursday March 13, 1941 , the last remaining work on the river project was completed and the gates opened and water returned to the entire downtown channel. The city and the Fiesta Commission arrived at a plan to present an extravaganza for the introduction of the restored river. "In what promises to be the most colorful and elaborate events ever staged during Fiesta de San Jacinto Week, King Antonio the XXIII will make his grand entry in a night fete in which about 100 boats will participate" (SAEN, 22 April 1941). Thus began the nighttime river parade tradition, still a popular highlight of each Fiesta Week.

On December 7, 1941, a surprise attack by the Japanese on Pearl Harbor provoked the United States into a declaration of war on all the Axis powers; America was again involved in a global war on both sides of her two oceans. Only six months after its completion, the festive frivolity of the carnival atmosphere for which the Riverwalk had been created seemed inappropriate in the face of the conflict that the nation now devoted her full effort toward ending. "War dethroned the King and Queen of the 1942 Fiesta de San Jacinto in San Antonio, but elevated their 'subjects' to the job of liquidating the dictators. San Antonio sacrificed this year's Fiesta and its climactic Battle of Flowers for the war effort" (SAEN, 24 April 1942). The press echoed the reality that had reached almost every family, that the men who had planned the spectacular 1941 activities "today have answered Uncle Sam's call" (SAEN, 24 April 1942). Only the solemn "pilgrimage to the Alamo" to honor the fallen who gave their lives for liberty seemed appropriate and was the only event conducted during the following five years.

San Antonio again turned its efforts toward what it had always done best: serving and training military forces. The ensuing years created a condition of benign neglect on the river, negating all of the charm that the beautification project had produced.

\section{Reviving the Intercity}

By mid-century the downtown sector of San Antonio had gone the way of most major cities in the nation. The lure of the suburbs had drawn most of the 
affluent downtown residents away from the heart of the city. Many of the larger stores had relocated to the suburban shopping malls along Loop 410. The beautiful Riverwalk envisioned by Robert Hugman had, for the most part, been realized, but its development, curtailed by World War II, had never reached its full potential. Without the riverfront business to draw both residents and tourists to the area, it had deteriorated into a slum-like area which, by the $1950 \mathrm{~s}$, was deemed too dangerous for military personnel and had been placed on the "off limits" list by local commanders. The residential areas in the midst of and surrounding the core city had, in most cases, aged to the point that they were very nearly beyond the point of feasible renovation and were ugly eyesores to greet the tourist seeking popular attractions such as the Alamo, the Spanish Governor's Palace, and $\mathrm{La}$ Villita.

Business owners in the heart of the city became concerned with the growing exodus of shoppers and diners and began to seek ways of bringing business and tourism back to the downtown area. In the late 1950s businessmen Arthur "Hap" Veltman and David Straus approached Harold Robbins, Chamber of Commerce, and Robert Frazier, director of the Parks and Recreation Department, with the concept of revitalizing the Riverwalk. A fund of $\$ 15,000$ was raised and matched by the city to obtain a feasibility study to determine the direction that should be taken along the river. This resulted in the creation of the Riverwalk District and Advisory Commission in 1962, and a master plan was developed and presented to the voters, who passed a $\$ 500,000$ bond issue in January 1964. At that time the Paseo del Rio Association, an advisory group of businessmen and property owners along the Riverwalk, was established (Zunker 1983:14).

The exodus to the suburbs was not just a local problem, but one that the nation faced in almost all major cities. Throughout the nation the decline of the central business district was causing widespread alarm, it meant the loss of patronage to downtown department stores, theaters, and restaurants (Banfield 1968:7). Those remaining in the cities did not have the expendable capital to support these businesses. But few private investors were willing to risk capital to construct low-cost housing and provide for those trapped in these slums by their restricted incomes. In an attempt to counter this trend, Congress enacted the federal Urban Renewal program in 1949. The goals were threefold: first, eliminate substandard and inadequate housing through clearance of slums and blighted areas; second, stimulate housing production and community development to remedy the situation; and lastly, realize the goal of a decent home and suitable environment for every American family. Vast amounts of federal money were given to cities to purchase slum areas, which were then sold to private developers for a few cents on the dollar to construct new, improved housing or public areas. After more than a decade of experience with the program, the general consensus of opinion was that the program had failed to produce significant benefits for a multitude of reasons (Anderson 1964:2-4).

\section{A New Approach: HemisFair}

By the late 1950s, San Antonio, like most urban centers, was searching for a new approach to make the urban renewal program effective. In 1959 local merchant Jerome Harris, executive vice-president of Frank Brothers, suggested a fair to acknowledge the cultural heritage of the city and the various nations of Latin America, a "Hemis-Fair" as he termed it. He proposed a recurring fair every two or four years on a permanent site (Tolson 1993). The idea rapidly received support among local groups and other merchants, and gained endorsement by Congressman Henry B. Gonzalez, who called for a "Fair of the Americas." It was recognized that in order to make the fair a reality, the support of the city government was essential. This meant convincing Mayor W. W. McAllister, a strong political opponent of Gonzalez, to render his support. The 79-year-old mayor agreed when it was understood that the plan must include the establishment of a civic center. As a symbol of their new-found unity, Gonzalez and McAllister were named as co-chairmen of the fair (Business Week 1968a). In 1962 San Antonio Fair, Inc., a non-profit organization, was established with William R. Sinkin as president and Henry B. Zachry as chairman of the board. Two years later Marshall Steves became president. The concept was accredited by the Bureau of International Expositions as a world's fair in November 1965 (Duane 1996:548-549). 
The concept of the fair was envisioned to address several development potentialities. First and foremost, it was directed toward reviving the lagging urban renewal program, but it was also designed to provide several long-range benefits for the city. Within the building design was the space for an arena/convention center complex, an extension of the newly awakening Riverwalk, and space for an educational complex. It would also provide a means of acquiring the right-ofway for a badly needed freeway linkage, which would be used during the fair as temporary parking. A desired downtown city services plant was incorporated, which was utilized to provide cooling and heating for the park as well. Planners hoped the fair would serve as a means of preserving a selection of homes displaying examples of nineteenth-century architecture which, following the fair, would be utilized to create a permanent Tivoli-type park within the central business district. It was further hoped that the effort would provide a rallying point for oftenfragmented civic development efforts (Montgomery 1968:84-89). All these lofty ideals had to be completed, from concept to construction, in less than six years.

With the vision of civic leaders such as architect O'Neil Ford, the rich potential of renovating the dilapidated near-east side into a permanent development to provide amusement and education for both citizens and tourists began to develop. The area had already been programmed for clearance and urban renewal, providing the necessary land accession and clearances, and the fair concept provided the impetus for public action to get the program moving again. HemisFair was financed by a combination of public funds and private investment. "Business leaders pledged the money not just because it was likely they would not be stuck with the tab-they were to be repaid through ticket revenue-but because it promised to push the city into a new era" (Tolson 1993). Public funding came from $\$ 12.2$ million from the United States Housing and Home Finance Agency, $\$ 11$ million in publicly approved city bonds for the convention center and arena, $\$ 5.5$ million in general revenues for the construction of the $622-\mathrm{ft}$ high Tower of the Americas, $\$ 10$ million of state funds primarily for the Institute of Texan Cultures, and $\$ 7.5$ million from Congress for the United States Pavilion (Duane 1996:549; SAEN, 16 February 1967). The 92.6-acre site was acquired, O'Neil Ford was selected as primary architect, and Allison Perry was named site-development director.

Many, including the San Antonio Conservation Society and residents of the HemisFair area, objected to the removal of so many historically significant structures. Ford's plan called for the preservation of 120 of the original structures, but other members of the committee insisted that this number was too high for the required site design. As a result of these objections, Ford, Peery, and Ewen Dingwell (coordinating architect) submitted a position paper reducing the number to "some 70 significant and substantial structures" (San Antonio Conservation Society Vertical Files [SACSVF], "A Chronological Report Concerning the Historic Structures in the HemisFair Area," May 7, 1964). In January of the following year, Mayor McAllister announced that, "no building will be destroyed in the HemisFair area until its historical background is investigated" (SACSVF, January 14, 1965). A special session of the Texas State Historical Survey Committee was convened in May 1966, and 29 structures within the area were designated Texas State Historic Landmarks (SACSVF, May 13, 1966). In September 1966, Ford was released from his contract, probably because of his insistence on saving many of the original structures, and was replaced by Allison Peery. The fight continued and Texas Senator Ralph Yarborough introduced an amendment to federal funding requiring fair officials to "preserve as many as possible of the historic structures on the site" (Duane 1996:549; SACSVF, September 8, 1966). Twenty-two survived (SAEN, 10 December 1965).

As construction was well under way in 1967 , city and fair officials became concerned that the city lacked sufficient hotel space to accommodate the anticipated flood of visitors or to support the convention center that was being created. When it became apparent that no private investor would come forth to alleviate the need, board chairman H. B. Zachry acquired a site on the Riverwalk and began construction of the 500room, 21-story Palacio Del Rio Hotel. Due to the short construction time and the limited access to the site, the guest units were constructed in modular units-each completely equipped with bath fixtures, air conditioning, carpet, and furniture-at a location seven miles from the site and hoisted into place to 
form the completed hotel in record time (Architectural Record 1968).

The focal point Tower of the Americas was also constructed in a unique manner. The main shaft of the structure was constructed first, as a poured-concrete unit. The 1.4-million-pound top house, containing observation decks and a rotating restaurant, was completed at ground level. This unit was then raised to the top, inch-by-inch, on 24 steel lifting rods, a process that took 20 days (Duane 1996:549). The actual construction of the tower progressed as planned, despite a hurricane that struck as the tower top house was being lifted; however, delays had been encountered during the bidding phase. When bids for the construction were received, the lowest bid$\$ 500,000$ under the estimate-was submitted by board member Dan J. Rheiner. When this became public, cries of conflict of interest were raised and Congressman Gonzales threaten to suspend his efforts for federal participation unless the project was rebid, with the result that the president of the San Antonio Tower Corporation, Marshall Steves, resigned from the board in protest. This forced reluctant Mayor McAllister to call for a bond issue to raise the money. As a result of these battles, the tower was not opened until a month into the fair (Pesquera 1993a).

\section{The Fair}

HemisFair opened on schedule April 6, 1968, with the theme "The Confluence of Civilization in the Americas" and marked the two hundred fiftieth year of the founding of the city (Architectural Record 1968; SAE 6 April 1968). The fair layout was designed as concentric triangles centered on the tower. Rides and amusements surrounded the tower in the first triangle, waterways were next, then smaller exhibition facilities, then the main pedestrian promenade with the large exhibition structures on the periphery. All this was laced together by several circulation systems: mini-rail, track-guided boats, a cabled sky-ride, and pedestrian walkways on elevated bridge structures. The First Lady, Mrs. Lyndon B. Johnson, opened the event. Her husband, burdened by the war in Vietnam and the assassination of the Reverend Martin Luther King, was unable to attend. Pavilions in the international area, "Las Plazas del Mundo," presented displays from more than 30 nations. Mexico, Spain, Canada, Italy, France, and Japan hosted major exhibits, while lesser displays represented Belgium, Bolivia, Portugal, China, Columbia, West Germany-Berlin, Korea, Panama, Switzerland, Thailand, and Venezuela. A Central American pavilion represented 11 other LatinAmerican countries. The United States Pavilion featured the fair's theme of "Confluence USA" with a 4.5-acre, two-building complex (Duane 1996:549). The largest structure, that of the Institute of Texan Cultures, featured the ethnic diversity of the state of Texas.

At the close of the fair, October 6, the total attendance was recorded at $6,262,397$, well short of expectations. With a start-up cost of $\$ 156$ million, the end result was a reported \$7.5-million loss. "Marshall T. Steves, HemisFair president, says the original underwriters will lose about $10 \%$ of their pledge, the second group between $40 \%$ and $50 \%$, and the third group will likely lose the full amount" (Business Week, 1968b:40). The general feeling among fair officials placed the blame on "poor management and overconfidence" (Business Week, 1968b:40). Most agreed that several factors had affected the attendance. The fair, opening the week of Dr. King's murder, followed by the assassination of Senator Robert F. Kennedy, was the victim of the fear of violence and unrest that had settled over the nation. The weather was another factor: the projected attendance depended heavily on local participation during the early stages, only to have record rainfall during the first three months. In September, the fair suffered yet another blow with a collision of the monorail which left one dead and 50 injured (Newsweek 1968:76).

Still, most saw the positive effects of the fair. Governor John Connally stated "HemisFair has presented Texas as a state which is proud of its past, humble in its present and with faith in its future" (SAEN, 6 October 1968). Others pointed out that the event had exposed more than six million visitors to San Antonio and had focused international attention on the city and its newly revived Riverwalk. The Chamber of Commerce produced figures indicating that the fair had, indeed, been a positive asset for the city. Of the visitors, more than 42 percent had been from out-of-state and other countries, and they had spent $\$ 122,500,00$ in the local economy. The city had 
gained 2,170 new motel units and 672 additional hotel rooms toward future business at the new convention center. In addition, the city had earned $\$ 8$ million in urban renewal credits (Steen, J. T., Economic Benefits from HemisFair; San Antonio Chamber of Commerce brochure, SACSVF).

\section{A New Plaza for the City}

At midnight of closing day, fair officials presented the keys to the grounds to Mayor McAllister as a symbol of the beginning of the city's adaptation of the site to fulfill the lofty hopes for its function of extended use toward the public good. The following day the city began "the orderly transition of HemisFair from a world's fair to a permanent municipal attraction" ( $S A E, 8$ October 1968). They were immediately served with a temporary restraining order prohibiting the "demolition, selling, leasing or transferring any improvements, facilities and properties" on the part of four local construction firms holding liens for money owed them for work on the fair (Slayman 1968). A local firm, Doyal Rogers and Wersham Brothers Company, presented plans for private development of the site with a $\$ 7.5$ million mix of public and private involvement. They proposed a new amusement park, a major hotel, and a public market and pavilion. The offer was rejected because the city council refused to allow privateers on the site (Pesquera 1993b).

A year later the new park still lacked direction. "In its first 12 months of life, HemisFair Plaza not only failed to break even financially but compiled a debt to be borne by other city revenue sources of $\$ 278,112$ " (Duffield 1969). The envisioned downtown university housed in a high-rise structure on the site was abandoned when The University of Texas System Board of Regents accepted a land donation of 600 acres northwest of the city (Whitson 1996:659). Although several of the permanent structures-the Convention Center, the Lila Cockrell Theater, and the Tower of the Americas-continued to be utilized, the unified downtown attraction envisioned by its planners was never realized.

The Institute of Texan Cultures continued with the same concept for which it had been conceived for the fair: displaying the cultural diversity of the heritage of the state. In 1968 the Institute participated in the
Smithsonian Institution's National Folklife Festival in Washington, D.C. Inspired by the success of their involvement at that event, the Institute began planning a festival of Texas's unique culture. Under the direction of the exhibits director, O. T. Baker, the country's first statewide folklife festival was held in September 1972. The festival was an immediate success, with paid admissions totaling $\$ 63,565$, with many more admitted free because the food booths ran out of food. In 1973, in the midst of the festival, the city was deluged by Hurricane Delia. The event was then moved to the first week in August to avoid September rains. In 1994 the two-millionth guest was recorded (Leatherwood 1996:334).

In the spring of 1986 , the city passed a $\$ 25$ million dollar revitalization plan for HemisFair Plaza. The plan called for an expansion of the convention center by 100,000 square feet, the construction of a water park, new facilities for Texas A\&M Extension Service and the National Autonomous University of Mexico (UNAM), a new parking garage, and the construction of a Sheraton Hotel on land provided by the city (Phillips 1987). At the end of May, Mayor Henry Cisneros donned a cape and waved a magic wand to signal a detonation that marked the beginning of construction of the \$9.3-million water park and Texas A\&M Extension building to replace the elevated walkways and water features of the fair (Brewer 1987). The design concept also included an extensive retail marketplace in the southwest corner linking the park and $\mathrm{La}$ Villita with a traffic circle on South Alamo Street (Martinez 1987).

\section{HemisFair Park}

Once again, the plan was abandoned within a year. The retail entertainment section envisioned for the park and La Villita had proved to be uneconomical, and was strongly opposed by the San Antonio Conservation Society. Several problems developed with the hotel, and the financiers for the Sheraton withdrew. Yet the city still felt the area held great promise and HemisFair Plaza was renamed HemisFair Park, with an eye toward developing a downtown central park and green space (SAEN, 18 March 1988, 10 June 1988). 
In April 1989, the park was the scene of the "greatest volunteer effort ever mustered in the city" (Corning 1989): 7,845 men, women and children arrived to construct a children's playground in the heart of the area. The concept was introduced by Margie and Charles O. Kilpatrick, publisher of the San Antonio Express-News, after they had helped construct a similar playground at Westside Park in Manhattan. The playground was the design of architect Bob Leathers who had supervised 450 such community parks in the United States and Europe. Working on the concept that the city would provide the land while the community would build the park, volunteers were recruited from all facets of the community. The city contributed one acre of land adjacent to the newly landscaped section of the acequia madre south of Goliad Street. Citizens, with the assistance of various skilled tradesmen and with materials and refreshments donated by various merchants, constructed the equipment (Corning 1989; Pesquera 1993b).

In the fall of 1989 , the city entered into a 25 -year lease with executive director Gerland W. Buech for the construction of a German Heritage Park to occupy the restored Victorian homes in and around the Goliad Street entrance to HemisFair Park. The \$5.5-million venture is to feature German-style food, music and entertainment to commemorate the largely unrecognized, but rich and colorful, German heritage that is an important part of San Antonio's cultural history. The German Heritage Park was expected to be completed by November 30, 1997 (Corning 1993); however, the association was unable to meet their commitments and the project has been delayed indefinitely. At the present the city staff is considering other viable alternatives to make the park a more productive feature of the central city.

The current project, expansion of the Convention Center, is a continuation of the evolution of HemisFair Park to best serve the needs of the city. Part II of this study details the specific history of HemisFair Park, with emphasis on the impact area for the proposed construction. 


\section{Part II: HemisFair Park and the Project Area}

\section{Introduction}

The Convention Center Expansion project area, as discussed in Part I, was originally used as agricultural fields for the Mission San Antonio de Valero (the Alamo). The area evolved from agricultural lands to one of the first residential sections of the city, then fell victim to urban decay. With the concept of HemisFair, the project area was revitalized. Construction of HemisFair began in 1966 amid the dilemma of how to move San Antonio into the future, yet still preserve an important segment of the city's rich historic past. The grounds of HemisFair Park contained a number of historically and archaeologically significant structures.

At the time of HemisFair, few laws, regulations, or guidelines concerning historic preservation existed. Accordingly, a full assessment of properties within the area was not conducted until 1983 (Cox and Fox 1983). By this time many of the original structures had been demolished or moved from their original locations. Prior to construction of HemisFair a compromise was reached: a group of buildings would be selected for preservation. Renovated and integrated as part of the exposition, some of these structures are still in use today. Most of these buildings are in the southwest corner of HemisFair Park in an area known as the Historic Triangle. This area is roughly bounded on the north by old Goliad Street, the east by old Water Street, the west by South Alamo Street, and the south by Durango Boulevard (see Figure 2). The original route of old Goliad Street was retained as a promenade through the fair grounds, and some of the preserved structures lay along this street. Also included in the original group of preserved buildings were several structures outside the Historic Triangle.

\section{Previous Archaeological Research}

Even though HemisFair Park covers a large and historically significant area, only a few archaeological investigations have occurred in the park (Cox 1992; Cox and Fox 1983; Fox and Cox 1990). Thus far these have mostly been restricted to the Historic Triangle area (Figure 5). No archaeological investigations have occurred in the area of the current convention center expansion.

The first archaeological investigation on the grounds of HemisFair Park was organized in preparation for the exposition. A section of the Alamo Acequia Madre (41BX8) was found during construction. The route of the acequia was easily traced by observing the ditch's stone walls. About $50 \mathrm{ft}$ of the acequia was visible at the surface within the Historic Triangle. Under the direction of Mardith Schuetz, curator of anthropology of the Witte Museum, volunteers excavated a short segment of the ditch (see Figure 5). The primary purpose of the excavation was to clean out a portion of the acequia so that it could be used as a water feature in the park's Spanish Pavilion (Fox and Cox 1990:3). The Schuetz investigation revealed that the bottom of the acequia was $5.2 \mathrm{ft}$ below the surface and the excavated section was $6.3 \mathrm{ft}$ wide. Walls of the acequia were lined with quarried limestone blocks varying in thickness from 10 to 14 inches, with lengths from 11 to 41 inches. A few latenineteenth-century household items were recovered (Schuetz 1970:7-13). Following the excavation, a circulating water system was installed. In addition, the southern part of the Spanish Pavilion and other structures were built over the acequia before its location could be accurately mapped. This effectively hid a large portion of the acequia and prompted subsequent archaeological investigations. 


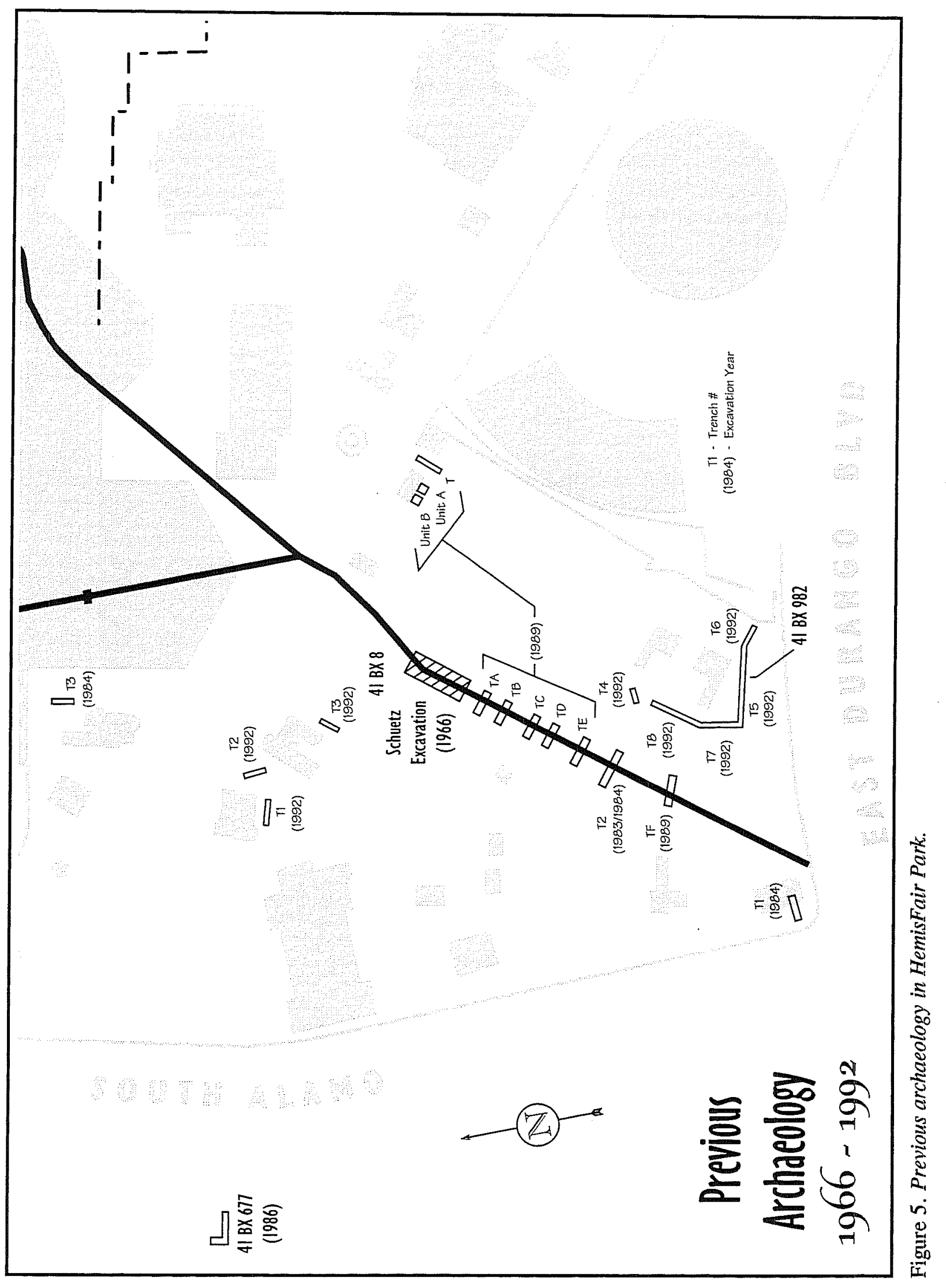


In December 1983, CAR conducted test excavations at HemisFair Park. The goal was to locate and document the condition of the Alamo Acequia Madre (41BX8). The project consisted of three backhoe trenches and hand excavations. A three-foot-wide trench was opened $35 \mathrm{ft}$ southwest of the south wall of the Transportation Museum (see Figure 5, Trench 2 northwest of Koehler House). A 10-ft section of the west end of the trench was excavated by hand, using picks and shovels, to a depth of about 20 inches. During this phase the crew also excavated a second test unit $6.5 \mathrm{ft}$ east of the original unit. The new unit was about $6 \mathrm{ft}$ long and revealed items similar to those excavated by Schuetz in 1966 . However, the acequia was not found.

The project was resumed on February 15, 1984, and the crew returned to the site with a backhoe. Trench 1 was opened near the intersection of South Alamo Street and Durango Boulevard (see Figure 5). Trench 2 was a re-excavation and extension of the test units started in December. The trench was deepened by several feet and continued east beyond the second unit. The acequia was finally located at the east end of the trench. The crew found evidence of the remaining limestone wall and a deposit of artifacts still appearing at five feet below the surface. Trench 3 was located on the north side of Goliad Street (see Figure 5, Trench 3 east of Mayer Halff House). This trench cut across the route of a lateral ditch which ran northwest off the main acequia. The ditch was merely an unlined, rather shallow trench dug into the soil. The project showed that the Alamo Acequia Madre (41BX8) was still in relatively good condition south of the Transportation Museum. Investigations also showed that the acequia does not run in a straight line from the Schuetz excavation to the intersection of South Alamo and Durango streets as previously expected. The exact route of the acequia south of Trench 2 remained open for investigation (Fox 1985).

In January 1989, in preparation for landscaping activities at HemisFair, CAR began another phase in the continued efforts to find and document the condition of the acequia. Given the difficulty of locating the acequia during Phase II of the previous project, the decision was made to proceed from the known portion at the north end with regularly placed trenches. The channel would then be located before proceeding to the next trench. Each trench had a width of four feet. The backhoe removed the upper layers of HemisFair fill, until the first signs of the acequia walls appeared. Excavation by hand was conducted below that point and screening was done through $1 / 4$-inch mesh. In the process, six test trenches were opened (see Figure 5, Trenches A-F). Data indicated that in most locations the east wall is in relatively good condition; in comparison, the west wall had been removed. Ceramics included unglazed, burnished, lead-glazed, and tin-glazed earthenware; whiteware; stoneware; yellowware; and porcelain. A few eighteenth-century sherds from Trench A were similar to those from the Schuetz excavation. Trench $A$ also produced the largest variety and number of sherds.

The project showed that the acequia is still present and that the stone removal took place at some time after trash deposits were accumulated. The trash fill in the acequia was deposited in a single operation after the ditch no longer carried water. After the project, stonemasons raised the acequia walls and poured a concrete bottom. This provided the shallow channel that now carries recirculating water through the northern half of the area (Fox and Cox 1990).

The Texas Antiquities Committee then recommended further testing. Two units and a backhoe trench were opened near the Smith House (see Figure 5, Unit A, Unit B, and Trench $T$ ) near the corner of Goliad and Water streets. Undecorated ceramics and cut nails dating to post- 1850 were found. This coincides with the period of the house construction. In addition, CAR recovered chert fragments that may indicate prehistoric occupation, as well as remains from the early twentieth century to recent times (Fox and Cox 1990:28).

In 1992 archaeological monitoring was conducted during utilities installation at HemisFair Park. Three trenches were monitored near the Hermann and Kampmann houses on old Goliad Street (see Figure 5, Trenches T1-T3). An additional five trenches were monitored near the Koehler and Espinosa houses on old Water Street (see Figure 5, Trenches T4-T8). Trench 5 revealed the foundation of the Huebaum House immediately south of the Espinosa House. This site was subsequently designated 41BX982 and represented the only significant cultural remains discovered during the project (Cox 1992). 
Although not located within the project area, La Villita Earthworks (41BX677) represents a significant archaeological site just to the west of the park (see Figure 5). Archaeologists retrieved material evidence associated with Mexican siege works. The site gives a comprehensive look at San Antonio in late February 1836, with General Santa Anna's forces during the second battle of the Alamo (Labadie 1986:I). HemisFair Park's close proximity to 41BX677, the San Antonio River, and the Alamo acequias greatly increases the area's potential for other significant archaeological discoveries.

\section{HemisFair Park}

Original boundaries of land parcels changed dramatically with the passage of time. Likewise street names and city block (CB) limits and designations have often undergone more than one modification. For the sake of clarity, we refer to the project area in terms of the streets and city blocks shown in Figure 6. These blocks do not reflect old suerte boundaries, as large suertes usually encompassed more land than one city block. Hence, the land owners listed below owned land somewhere within the referenced city block. These owners may have had relatively large parcels, but they did not necessarily own all the land within the limits of the modern blocks. Table 3 summarizes the property ownership west of Water Street in HemisFair Park. Photographs of selected structures within HemisFair Park are presented in Appendix A.

\section{After Secularization}

After secularization, the land comprising the project area was granted to the Adeasaños. Those granted tracts within the study area were Jose Serafin Manzolo, Miguel Antonio (Tomás) Martinez, José Alcala, and Tomás Maldonado (Chabot 1937:216; City Engineer's Map 1916, copy on file at Center for Archaeological Research, The University of Texas at San Antonio). At the same time, José Refugio Amador acquired a tract of land to the west of the acequia (BCDR, X1:329). Refugio was the secondborn son of Vicente Ferrer Enriques Amador, who was in charge of the Mission Valero lands and helped survey the lands for distribution (Chabot 1937:194).
The wave of immigration into Texas resulting from the rumored Louisiana Purchase brought new citizens into San Antonio. Joseph de la Baume, born in France in 1731, came to America with General Lafayette and fought in the American Revolution. With the outbreak of the French Revolution in 1789, La Baume was unable to return to his native land. He enlisted in the Spanish military and rose to the rank of lieutenant in the Quachita militia, where he became acquainted with Felipe Enrique Neri, Barón de Bastrop. They became lifelong friends and their careers remained intertwined. With the Louisiana Purchase, La Baume removed his family to Nacogdoches to avoid French rule. While awaiting permission to serve under General Salcedo, he married Felicina, a 30-year-old mulatta as his third wife. He arrived in Bexar in 1806, and in 1808 through 1810 acquired the Martinez tract (Figure 7) where he constructed his stone house on the Alameda (Jackson 1986:474-475; BCDR, J1: 8,10). La Baume was probably accompanied by his old friend, the Baron de Bastrop, who purchased tracts that had also been granted to Adaesaños in the adjacent area, as well as the Refugio Amador suerte (BCDR, A2:303).

The self-styled Barón de Bastrop was born Philip Hendrik Nering Bogel in Paramaribo, Dutch Guiana, on November 23, 1759. He returned with his parents to Holland in 1764, and in 1779 enlisted in the cavalry. He married and had five children, but left Holland in 1793. He used the French invasion of Holland as his reason, but in reality he fled the country because he had been charged with embezzlement of tax funds. With a reward of 1,000 gold ducats on his head, he adopted the title Barón de Bastrop. By 1795 he had drifted to Spanish Louisiana where he persuaded the government to allow him to establish a colony in the Quachita valley. After the Louisiana Purchase, he relocated to Spanish Texas and established a colony near the Trinity River. Upon his arrival in San Antonio, he established a freighting business, and in 1810 was appointed an alcalde in the city council. He is probably best remembered in Texas history for his intervention on behalf of Moses and Stephen Austin to allow the establishment of their AngloAmerican colony. In 1823 Bastrop was appointed commissioner of colonization for the Austin Colony. In May of the following year he served as the colony's representative to the legislature of the newly formed state of Coahuila y Texas. He was instrumental in passing the colonization act of 1825 , establishing a port at 


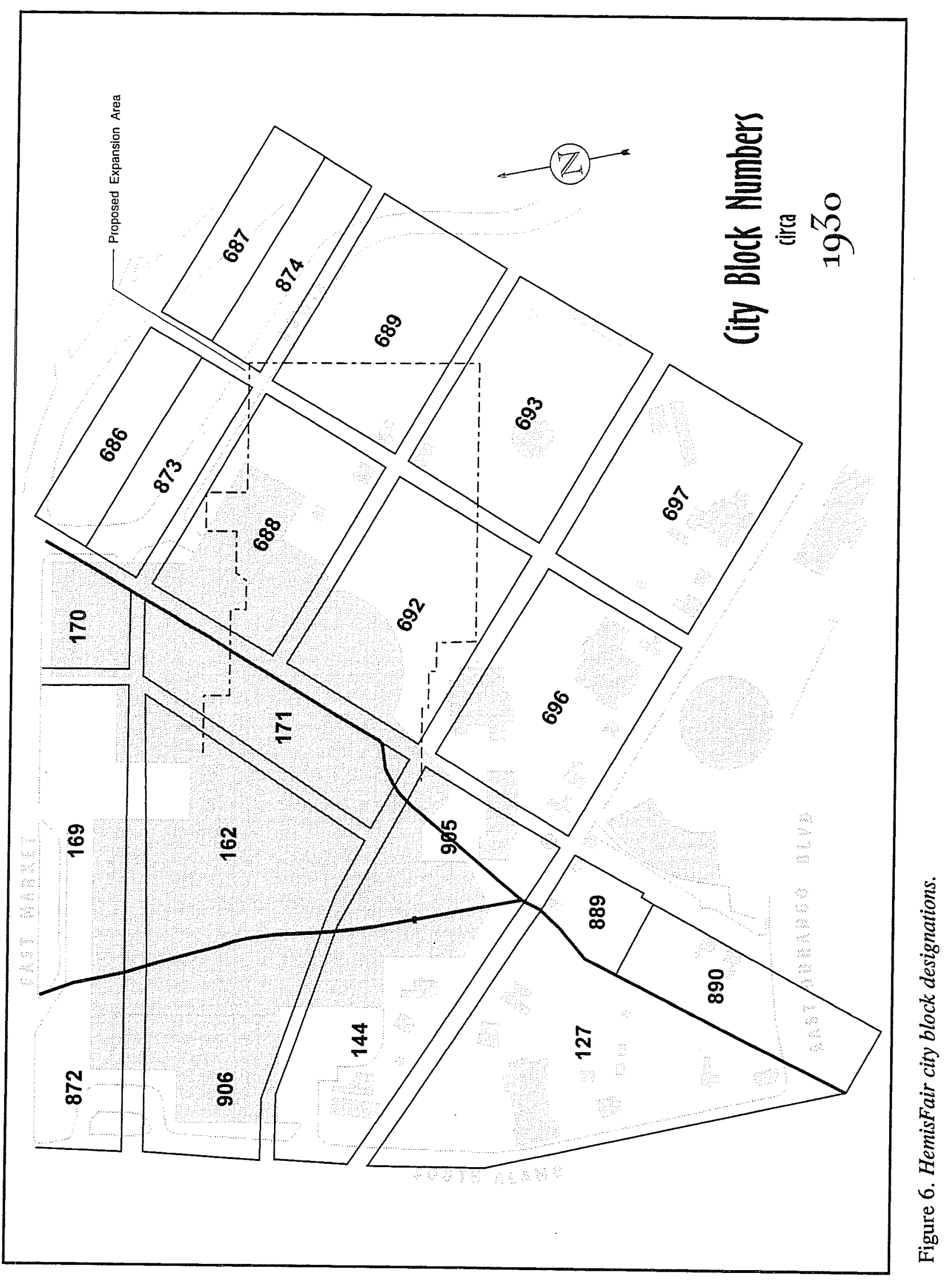




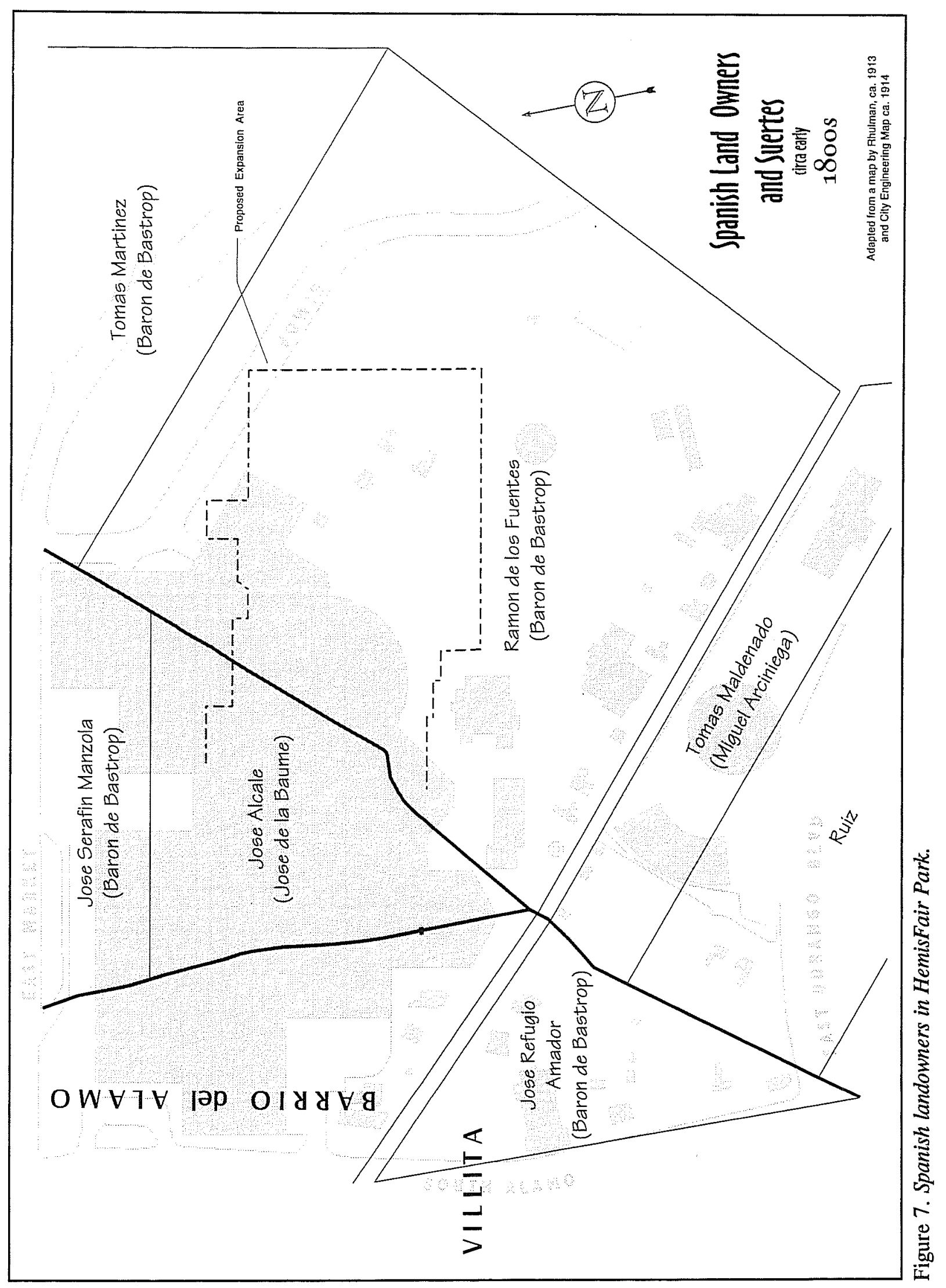


Table 3. Property Ownership within the Convention Center Expansion Area

\begin{tabular}{|c|c|c|c|}
\hline Block & Owner & Acquisition Date & BCDR Source \\
\hline \multirow[t]{3}{*}{ CB 127} & John Riddle & March 1841 & A2:403 \\
\hline & & November 1844 & $\mathrm{C} 2: 287$ \\
\hline & & August 1871 & W1:329 \\
\hline \multirow[t]{6}{*}{ CB 144} & Philip Dimmitt & October 1829 & A2:306 \\
\hline & Bryan Callaghan & March 1845 & $C 2: 49-50$ \\
\hline & Sarah A. Evans & May 1847 & $\mathrm{E} 2: 260$ \\
\hline & Joseph Beck & October 1848 & G1:441 \\
\hline & Joseph Beck & October 1848 & G1:465 \\
\hline & George Howard & November 1861 & S2:171 \\
\hline \multirow[t]{9}{*}{ CB 162} & Joseph (Jose) de la Baume & March 1810 & $\mathrm{~J} 1: 10$ \\
\hline & John P. Erskine & November 1844 & B2:240 \\
\hline & Getrudes de la Baum Estes & January 1850 & $\mathrm{~N} 1: 546$ \\
\hline & John Twohig & January 1850 & $\mathrm{~N} 1: 546$ \\
\hline & Garret P. Post & January 1853 & K2:606 \\
\hline & P. C. Taylor & December 1854 & M2:399 \\
\hline & Carl Kaiserling & April 1860 & $\mathrm{~S} 1: 216$ \\
\hline & Bathasar Benner & February 1864 & $\mathrm{~T} 1: 170$ \\
\hline & Ignaz Meyer & April 1869 & $\mathrm{~V} 2: 137$ \\
\hline \multirow[t]{5}{*}{ CB 169} & Joseph (Jose) de la Baume & February 1808 & $\mathrm{~J} 1: 8$ \\
\hline & John P. Erskine & November 1844 & B2:240 \\
\hline & John Twohig & January 1850 & $\mathrm{~N} 1: 546$ \\
\hline & Garret P. Post & January 1853 & $\mathrm{~K} 2: 606$ \\
\hline & Carl Kaiserling & January 1859 & R2:542 \\
\hline \multirow[t]{2}{*}{ CB 170} & Joseph (Jose) de la Baume & February 1808 & $\mathrm{~J} 1: 8$ \\
\hline & John P. Erskine & November 1844 & B2:240 \\
\hline \multirow[t]{6}{*}{ CB 171} & Joseph (Jose) de la Baume & March 1810 & $\mathrm{~J} 1: 10$ \\
\hline & John P. Erskine & November 1844 & B2:240 \\
\hline & John Twohig & January 1850 & $\mathrm{~N} 1: 546$ \\
\hline & Garret P. Post & January 1853 & K2:606 \\
\hline & Barney Mitchell & August 1855 & $\mathrm{~V} 1: 384$ \\
\hline & Henry Hockenkemper & January 1867 & V1:385 \\
\hline \multirow[t]{6}{*}{ CB 872} & Jose Leal & November 1822 & $\mathrm{H} 1: 354$ \\
\hline & Anthony Superville & October 1856 & $\mathrm{O} 2: 617$ \\
\hline & Benito Lopez & October 1863 & $\mathrm{~T} 1: 151$ \\
\hline & Augustine Morrisset & January 1864 & $\mathrm{~T} 1: 152$ \\
\hline & Rafael Lopez & August 1866 & W2:440 \\
\hline & Feliciano San Roman & June 1872 & $11: 370$ \\
\hline \multirow[t]{3}{*}{ CB 889} & Sam Smith & June 1857 & $\mathrm{P} 1: 309$ \\
\hline & Maria Dolores Delgado y Cantu & November 1858 & $\mathrm{R} 2: 609$ \\
\hline & Walter Tynan & January 1859 & $\mathrm{R} 2: 495$ \\
\hline
\end{tabular}


Table 3. continued

\begin{tabular}{||l|l|l|l||}
\hline Block & \multicolumn{1}{|c|}{ Owner } & \multicolumn{1}{|c|}{ Acquisition Date } & \multicolumn{1}{|c|}{ BCDR Source } \\
\hline & F. P. J. Meyers & October 1856 & O2:110 \\
\hline & August Heubaum & October 1859 & S1:29 \\
\hline CB 905 & Joseph (Jose) de la Baume & March 1810 & J1:10 \\
\hline & John P. Erskine & November 1844 & B2:240 \\
\hline & John Twohig & January 1850 & N1:546 \\
\hline & Garret P. Post & January 1853 & K2:606 \\
\hline
\end{tabular}

Galveston, and other legislation favorable to the colonist. Bastrop died February 23, 1827, in Saltillo, Mexico (Moore 1996:410).

Another important early landowner was Miguel Arciniega. In 1811 Arciniega acquired a tract in the southern portion of La Villita (see Figure 7), as well as the Tomás Maldenado suerte to the east of the water gate and south of the road to La Bahia (Bexar County Archives [BCA], "Land Grants and Sales," Document 40). José Miguel de Arciniega was the son of Josefa (Flores) and Gregorio Arciniega, the latter was a soldier with the San Carlos de Parras del Alamo Company. Miguel Arciniega also joined the military and rose to captain of the civil militia. In 1827 he was elected, with Jose Antonio Navarro, deputy to the state congress in Saltillo where they managed to pass a law allowing slavery in Texas. In 1833 Arciniega served as alcalde of Bexar and served as political chief during the illness of Músquiz. Appointed as land commissioner for Austin's colony, he signed the four-league grant for the town of Bastrop and, with Samuel May Williams, surveyed the town site. He served as interpreter for General Cós at the surrender of Bexar in 1835. He married Alejandra Losoya, with whom he had five children (Johnson 1996:234-235).

After the death of the Barón de Bastrop, his heirs conveyed his property, including lands in the project area, to Philip Dimmitt in December 1829 (BCDR, A2:306). Dimmitt, a major figure in the Revolution, was born in Jefferson County, Kentucky, about 1801. He arrived in Texas-with a letter of introduction to Stephen F. Austin-in 1823. After his purchase of the Bastrop property, he settled into La Villita and became a commissary contractor to the Mexican garrison nearby. He married Maria Luisa Lazo, from whom he received a three-league grant and established a ranch near the town of Guadalupe Victoria. Dimmitt amassed a considerable fortune through a series of trading posts he established. In 1835 he joined the George Collinsworth expedition to capture Goliad. After the capture of La Bahía, he was elected captain of the volunteers. While in command of Goliad, from October 1835 to January 1836, Dimmit designed the green-white-red flag with 1824 emblazoned upon it which became the unofficial flag of the Revolution. While in command of Goliad, he led a force to participate in the Battle of Bexar in December 1835 . In January Dimmit returned to Bexar with 30 volunteers and was made army storekeeper. While scouting for Travis, he was cut off from the fort by the arrival of the Mexican army and retreated to Victoria. Sam Houston ordered Dimmitt and his volunteers to join him at Gonzales, but found it occupied by Mexican forces. Dimmitt was the first to bring fresh supplies to Houston's army after San Jacinto. After the Revolution, Dimmitt was appointed a judge in Refugio. He and others were captured by Mexican forces in July 1841 . With a warrant on his head for his participation in the Revolution, he was placed in irons and marched to Monterrey, en route to prison in Mexico City. At Saltillo a number of the party managed to escape, and Dimmitt was informed that he would be shot if the prisoners failed to surrender. Rather than face execution or imprisonment, he ended his life with an overdose of morphine (Roell 1996:648-650).

On March 4, 1845, Dimmitt's heirs sold a portion of his properties to Bryan V. Callaghan, Jr. (BCDR, C2:49-50) the son of Bryan and Concepcion (nee Ramón) Callaghan. Callaghan was born in San Antonio on April 1, 1852. He was educated at St. Mary's Institute, the Lycée de Montpelier, and 
received his law degree from The University of Virginia. In 1879 he married Adele Guilbeau in San Antonio, and that same year was elected alderman. He was elected for his first term as mayor in 1885 , and held that position until 1892 , when he resigned to successfully run for the seat of county judge. He returned to the position of mayor in 1897 , but when defeated for that position in 1899 , he returned to private practice. He was again elected mayor in 1905 , and held that position until his death in 1912. With his multi-cultural heritage, Callaghan had ties to the Irish, French, and Hispanic elements of the city; he spoke English, Spanish, French, and German fluently. He assembled such a powerful political machine that he was often referred to as "King" Callaghan. His administration is noted for its use of patronage, opposition to reform, leniency toward vice, and favoritism in awarding of contracts. However, it is acknowledged that his administrations expanded the fire and police departments, purchased the waterworks, paved the streets, and expanded the schools and hospitals. Callaghan did not benefit directly from any of his works, and died with no personal fortune (Doyle 1996:904). Bryan and Adele sold the property to Sarah A. Evans in 1847, who in turn conveyed it to Joseph Beck in 1848 (BCDR, E2:260, G1:441, 465).

José Miguel Arciniega mortgaged his 20 town lots to John Riddle in 1841, and transferred ownership to him in 1844 (BCDR, A2:403, C2:287). John Riddle was acting as agent for his brother, Wilson I. Riddle. The latter was born in Ireland in 1812, arrived in San Antonio in 1839, and established himself as a successful merchant. He married Elizabeth Mary Menfree in April 1841 in Tennessee. Wilson and his brother were among the prisoners taken to Mexico by General Woll in 1842 (Brown 1996:112). As a result of illness contracted during his incarceration in Mexico, Wilson died in San Antonio on September 12, 1847 (Chabot 1937:300). The property passed to his widow, later Elizabeth Canterbury, and then to their daughter, Sarah Eager, who was residing on the property when she was evicted for the construction of HemisFair in 1967.

The La Baume property was sold by his estate to John P. Erskine in January 1844 (BCDR, B2:240). Erskine was born in Monroe County, Virginia, one of 10 children of Agnes D. and Michael H. Erskine. The family moved to Alabama in 1831, and in 1834 to Bolivar, Mississippi. In 1839 the family relocated to Jackson County, Texas, where the following year their home was attacked by a scouting party of Comanche Indians on their way to raid Linnville, Texas. The family then settled in present-day Guadalupe County. In 1847 John, with his Texas Ranger brother Andrew, surveyed the lands for Castro's colony (FitzSimon 1996:884-884).

One of the most important land owners in the project area was Joseph H. Beck. Beck and his family came to Texas between 1840 and 1843. Although the 1860 U.S. census listed his wife Sarah as a native Georgian, the 1850 census notes her as 31 years old with Alabama as her place of birth. Their two eldest children-Mary, 12, and Joseph, 11-were both born in Alabama. The next child listed was seven-year-old Josiah, born in Texas. The 1850 census also lists the South Carolina-born Joseph $H$. Beck as a 49 year old farmer whose land was worth $\$ 6,000$. In 1860 his personal real estate reached $\$ 7,000$, while his total land holdings were valued at $\$ 16,000$. He was not listed in Bexar County in the 1870 U.S. census, indicating he had moved or was deceased.

In October 1848, Beck obtained property in CB 144 from Sarah and Matt Evans (BCDR G1:441, G1:465). During the same month, Matt Evans also sold Beck a large tract east of the Alamo Acequia Madre (BCDR G1:447). Beck became one of the most active land speculators in the project area, he is listed as the grantor or grantee in more than 100 transactions between 1848 and 1860 .

\section{East of Water Street: Beckville}

The area in HemisFair Park east of Water Street was once part of the community known as Beck's Division or Beckville. The footprint for the convention center expansion lies within the boundaries of Beckville (Figure 6). New areas affected by construction activities will affect portions of city blocks 688, 689, 692, 693, 873, and 874. Appendix B traces early lot ownerships for all of Beckville, including the project area.

The deed records from 1845 describe the extent of a certain tract as being "bounded on the west by the main ditch, on the east by the lands known at the time 
of purchase by the Baron de Bastrop as Royal Lands, on the north by other lands at that time owned by Baron de Bastrop" (BCDR C2:121). A more detailed description of this same tract was given from an 1848 transaction. This record states that the land was "bounded west by the main ditch extending from Goliad Road, up said ditch to an old stone dam pointed out by José Antonio de la Garza who formerly owned said tract of lands bounded south by the Goliad Road extending 440 varas and running northeast as designated by the present line of fence thence west to the said dam" (BCDR, G1:447).

The original land that was to become known as Beckville was once the suerte of Ramon de los Fuentes (see Figure 7). The Spanish government granted him this tract in 1794 . In November 1808, he sold the parcel to José Antonio de la Garza, the same man who pointed out the location of the old stone dam on the property's northwest corner. Eight years later, de la Garza sold the real estate to the Baron de Bastrop. In October 1829, Philip Dimmitt purchased the land from the heirs of Bastrop. After Dimmitt's death, William E. Jones acted as administrator for Dimmitt's heirs and sold the old suerte to Volney E. Howard at a public auction in June 1845. Next in the line of owners was Matt Evans. Evans bought the old suerte in April 1848 then quickly resold it to Joseph Beck in October of the same year (BCDR C2:121, $\mathrm{G} 1: 447, \mathrm{~N} 1: 226)$. Until this time the land had remained intact as one large, undeveloped parcel. Joseph Beck took the first steps to making this a residential area: he had the suerte divided into blocks and town lots.

In 1848 the land was surveyed and subdivided into lots and city blocks by the deputy city surveyor W. S. Smythe. It was common practice to describe the limits of a parcel by fixed objects and by the neighbors adjacent to the property. Although the fixed objects were usually natural, they could also be large manmade objects. Hence, early records are replete with references to trees, boulders, waterways, stone dams, fence lines, fence posts and the like. Spanish land measurements were still in use throughout most of the nineteenth century and were reflected in the deed records of the time. The vara-equivalent to about $33 \frac{1}{3}$ inches-was the main unit of measurement. A square vara equaled 7.7 square feet, 0.86 square yards, or 0.00018 acres; while a labor had $1,000,000$ square varas or 177.1 acres (Dobkins 1959:2).

Most Beckville lots measured 20 varas $(55.5 \mathrm{ft})$ along the front and 50 varas (139 ft) in depth, with an area of 1,000 square varas (Figure 8). Most blocks were identical, containing 16 lots. Eight lots fronted a north side street, while a like number of tracts fronted a street on the block's south side. The entire block measured 160 varas ( $444 \mathrm{ft}$ ) east to west along its front by 110 varas $(305 \mathrm{ft}$ ) in depth. An alley 10 varas ( $28 \mathrm{ft}$ ) wide ran east to west through the center of the blocks. A few parcels were located on fractional blocks and were the exceptions to these standard sizes.

After the Smythe survey, Ramón de las Fuentes's old suerte became 130 Beckville lots (see Figure 9). New streets, blocks, and alleys formed by the survey were named and numbered. Beckville block designations were subsequently converted to the city block numbers. Likewise, in time, some of the street names were also changed. In March 1881, Second Street became Matagorda and Third Street was changed to Indianola (CD 1881). Later, Centre Street was renamed Wyoming. Just prior to HemisFair 1968, old Beckville was bounded on the south by Goliad Street, west by Water Street, north by North Street, and east by Indianola Street. Beckville's narrow alleys were also eventually named. Rose Alley was between North and Wyoming streets. Haller Alley ran between Wyoming and South streets, while Arroyo Alley paralleled South and Goliad. A building that fronted an alley usually had a separate address from the structure that faced the main avenue. Beckville contained city blocks $688,689,692,693,696,697$, 873 , and 874 , and also extended to fractional blocks immediately east of Indianola Street (see Figure 9).

The stone dam described by José Antonio de la Garza would have been located near the intersection of present day Bowie and East Market streets (see Figure 9) near the north corner of Beckville. It probably fed a small lateral or irrigation ditch that branched off from the Alamo Acequia Madre and formed the northern boundary to city blocks 873 and 874 in Beckville. A map of San Antonio circa 1800 (see Figure 4) also shows two laterals that would have been on the west side of Water Street. The Beckville ditch may have been another independent ditch or 


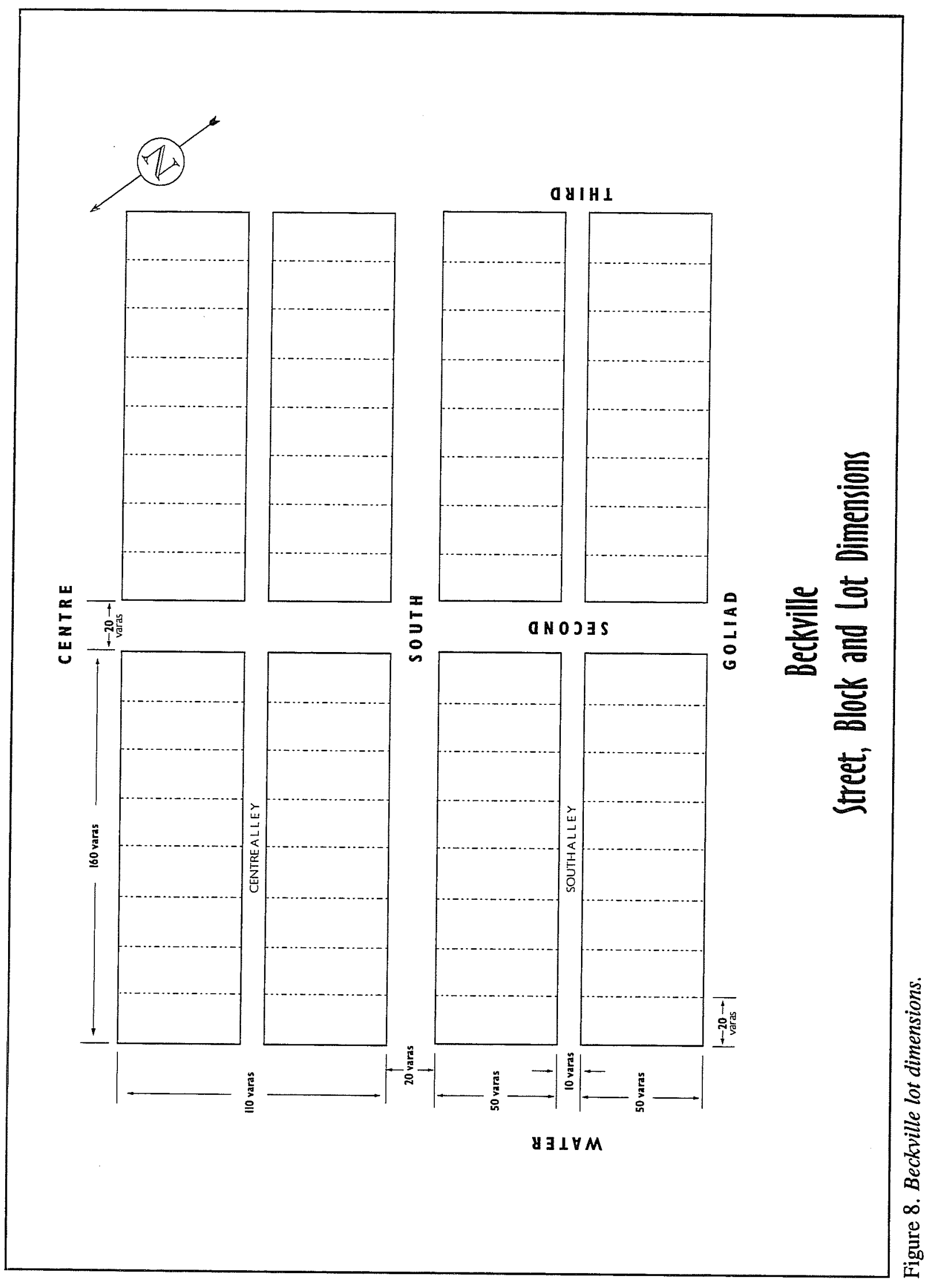




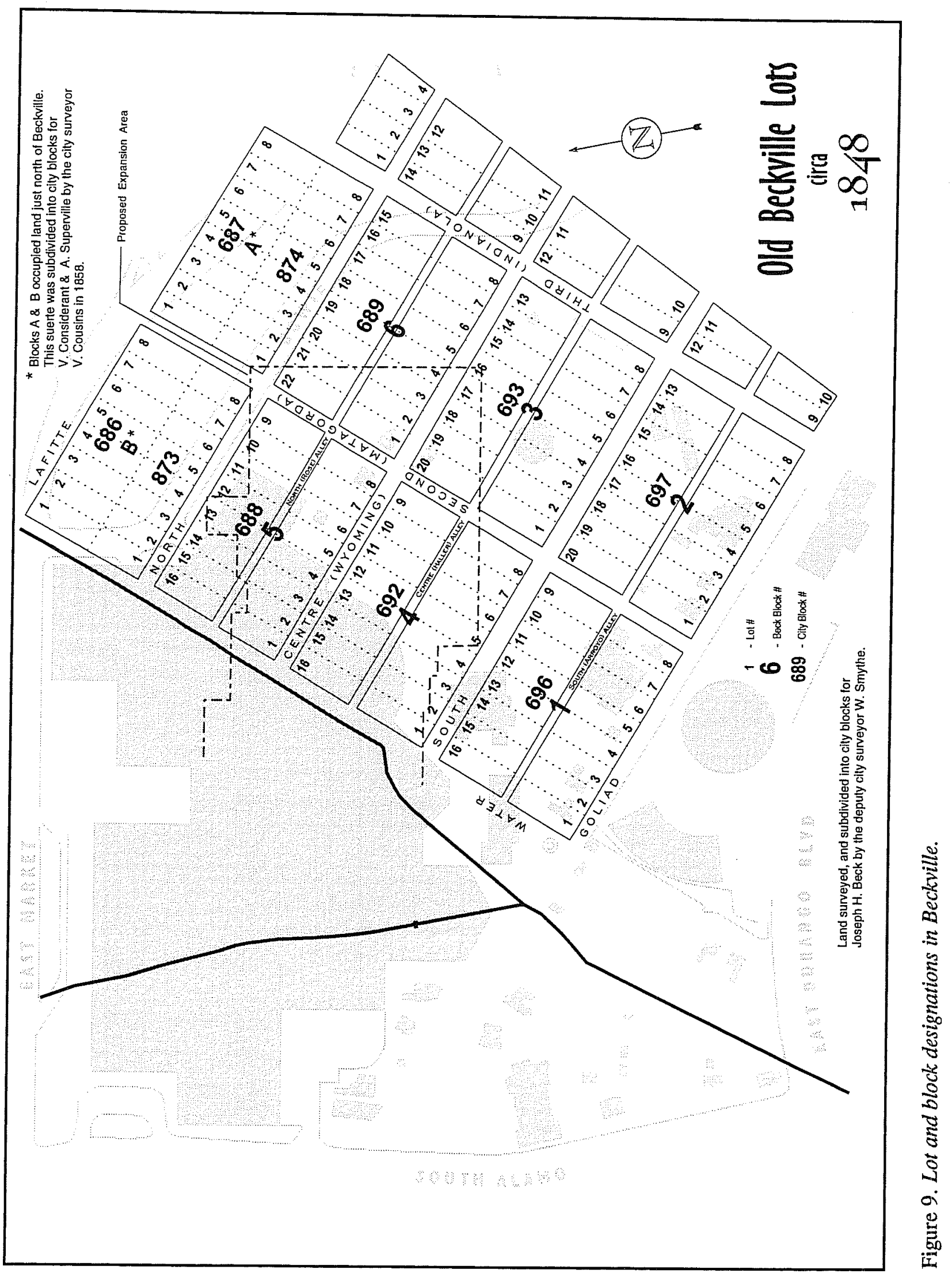


possibly an extension of one of these existing laterals. A few deed records do refer to an irrigation ditch in Beckville. The 16 lots on CB 873 and CB 874 and the four lots east of Third Street were only 40 varas in depth instead of the usual 50 varas (see Figure 9). According to some records, the Beckville ditch not only provided water, it also established the northern boundary line for the community (BCDR P2:472, P2:526).

Volney Howard had purchased the entire Fuentes suerte for only $\$ 100$ at the auction in 1845 . Joseph Beck paid Matt Evans over $\$ 600$ for the suerte just three years later (BCDR G1:447). This was a fair sum of money in 1848 . Nevertheless, as a business venture, there was the opportunity to make a large profit. Early transactions in Beckville show that the lots were selling for $\$ 75$ to $\$ 125$ each. If all 130 lots were quickly sold at an average of only $\$ 100$ apiece, Joseph Beck would have received about $\$ 13,000$. This meant a profit of around $\$ 12,500$ above his initial investment. However, the new neighborhood got off to a slow start and Beck did not sell the last of these tracts until June 1860 . It took nearly 12 years for Joseph Beck's name to finally drop from the roll of Beckville's real estate transactions. Shortly after the land was subdivided, Beck encountered a major, unforeseeable obstacle to his plans: cholera.

Cholera, a disease usually spawned by contaminated water supplies, ravaged San Antonio in 1849 and again in 1866 . Drinking water was obtained from shallow wells and the acequias until the new water works began pumping water from the river in 1878 (Ramsdell 1985:52). Until that time, the city's water supply regularly became contaminated from outhouses. Besides cholera, typhoid fever and malaria were also prevalent (Ramsdell 1985:45). Before the 1849 epidemic ran its course, the cholera plague claimed more than 500 lives. As a result, many residents fled the city just as Beckville was getting started (House 1968[1949]:106). Nevertheless, this was only a temporary setback. The community overcame the plague of 1849 and many other hurdles in the years that followed.

The following newspaper announcement, which appeared in an 1868 edition of the San Antonio Express-News, reflects the neighborhood's status 20 years after Beck's initial survey.
For Sale At Public Auction By David Friedlander \& Co. Improved City Property. Will be sold on Friday, July 17th, at $10 o^{\prime}$ clock, A.M. In front of the premises, the House and Lot of Ground situated at the north-east corner of Goliad and Second streets, east of Alamo ditch. The house is of hard rock, with a cellar attached, and a fine well of water. The property is in a pleasant neighborhood, well surrounded by excellent improvements and in one of the most thriving and prosperous portions of the city. Terms stated on day of sale. Act of sale including Internal Revenue stamps at expense of purchaser. For further information apply to DA VID FRIEDLANDER \& Co. [SAE 4 July 1868 , emphasis in the original].

By 1868 most of the project area was indeed a pleasant and prosperous neighborhood. The house and lot in the above newspaper announcement was located on Lot 1 of Beck Block 2, at 401 Goliad Street. Known as the Richter house, it still stands on the same corner. Appendix A (Figure A-15) shows the one-story limestone structure when it was Ray's Cleaners, circa 1966. One hundred years after the newspaper ad, during HemisFair 1968, the building was remodeled and served as a Gay Nineties Restaurant (Wall 1968:114).

Lot 2, immediately east of the Richter house, also has a standing structure (Appendix A, Figure A-17). The former address there was 405 Goliad Street. Sometimes called the Tynan Brothers or Coyne house, Eileen B. Coyne lived there until 1960. The photo shows the main structure and a small building in back as they looked around 1966. Both units were subsequently remodeled and used during HemisFair. During the exposition it was a Mexican bakeryrestaurant, called the Don Pan Dulce (CD 1960; Wall 1968:114).

Along with street, lot, address, and owner name changes, some properties appear to have conflicting historical data. Add to these the passage of time and missing records, it is easy to see why the histories of some houses may be difficult to interpret. The Richter house is one of a few structures in HemisFair Park with a confusing background. A few sources mention the possibility of a very early (pre-1800) construction date for the Richter house (Wall 1968:116). Likewise, 
the structure is named for a man who is said to have operated a merchandising business from the property in the 1850s. However, other sources suggest that if the building was there, Mr. Richter may have just been a tenant. These deed records suggest that he did not own the property until after the Civil War. The histories of both the Richter and Tynan lots can be traced back to their original sale from Joseph Beck. In fact, the early history of Lots 1 and 2 of Beck Block 2 (CB 697) are identical.

Walter C. and Edward K. Tynan purchased two lots from Joseph Beck for $\$ 130$ in February 1857. Some confusion may stem from the small building in back of 405 Goliad. Certain sources appear to have counted the dependency parcel as a second lot and in the process omitted the Richter lot on the corner. The deed record for the Tynan transaction states that the lots were bounded west by Second Street, north by the alley, east by Lot 3 and south by Goliad Road (BCDR, P1:422). The corner lot described in the newspaper ad and the adjoining one are clearly included within these limits.

The Tynan brothers sold the same two lots to Emanuel Rzeppa in December 1859 for $\$ 250$ (BCDR $\mathrm{R} 1: 636)$. The low price suggests that the lots were still unimproved at this time. Finally, in $1868, \mathrm{Mr}$. Richter bought the lots from Emanuel Rzeppa for $\$ 2,200$ (BCDR U1:495). City directories ([CD], San Antonio Public Library, San Antonio, Texas) and the deed records suggest that the structures were built between 1859 and 1868 while Mr. Rzeppa still owned the tracts. Ramon Treviño had the building most of the years just prior to HemisFair 1968. City directories (1955-1956, 1960) and the photo show that this was a dry cleaning establishment called Ray's Cleaners in 1966. In an interesting note, the date of Richter's transaction was July 18, 1868. The real estate sale and auction, publicized in the San Antonio Express-News, was held the day before. It seems evident that Carl August Richter attended the sale and settled for the terms.

A growing multi-cultural residential district led to a variety of small businesses and churches. The city also acquired lots for schools, fire stations, and other services to support the neighborhood. By the 1870 s, Beckville was a well-established community. In 1873,
Augustus Koch preserved a unique glimpse of this area in his drawing entitled Bird's Eye View of the City of San Antonio (Figure 10).

\section{Lot Histories Within the Construction Area}

Individual lot histories have been collected for three structures - the Wietzel House, the Amaya House and the $\mathrm{O} \mathrm{K} \mathrm{Bar}$-and lots without existing structures in the new expansion area (Figure 11). This project will affect a few tracts along North and South streets. However, Wyoming Street runs directly through the target area and construction activities will have the most impact on the properties which once lined this old avenue. The three historic homes will be relocated outside of the immediate area but will remain within HemisFair Park (Johnson and Cox 1995).

Besides deed records, Augustus Koch's 1873 drawing Bird's Eye View of the City of San Antonio and the 1896 Sanborn Insurance Map (Figures 12 and 13) were used to determine when a structure first existed on a lot. For convenience these early sources will hereafter be referred to by the following shortened names: Koch's drawing and the Sanborn map. In addition, the following city directories were used in conjunction with the deed records: $1877,1891,1903$, $1905,1907,1913,1914,1915,1919,1929,1951$, 1955,1960 and 1965.

\section{Standing Structures}

Three structures-the Wietzel House, the Amaya House, and the OK Bar-dating from the last century are still standing in the footprint of the Convention Center expansion (see Figure 13). These are discussed individually with their relocation sites. All three structure lots were part of transactions which included adjoining lots. Although now vacant, contiguous lots that share a common history with standing structures are discussed with the structure. 


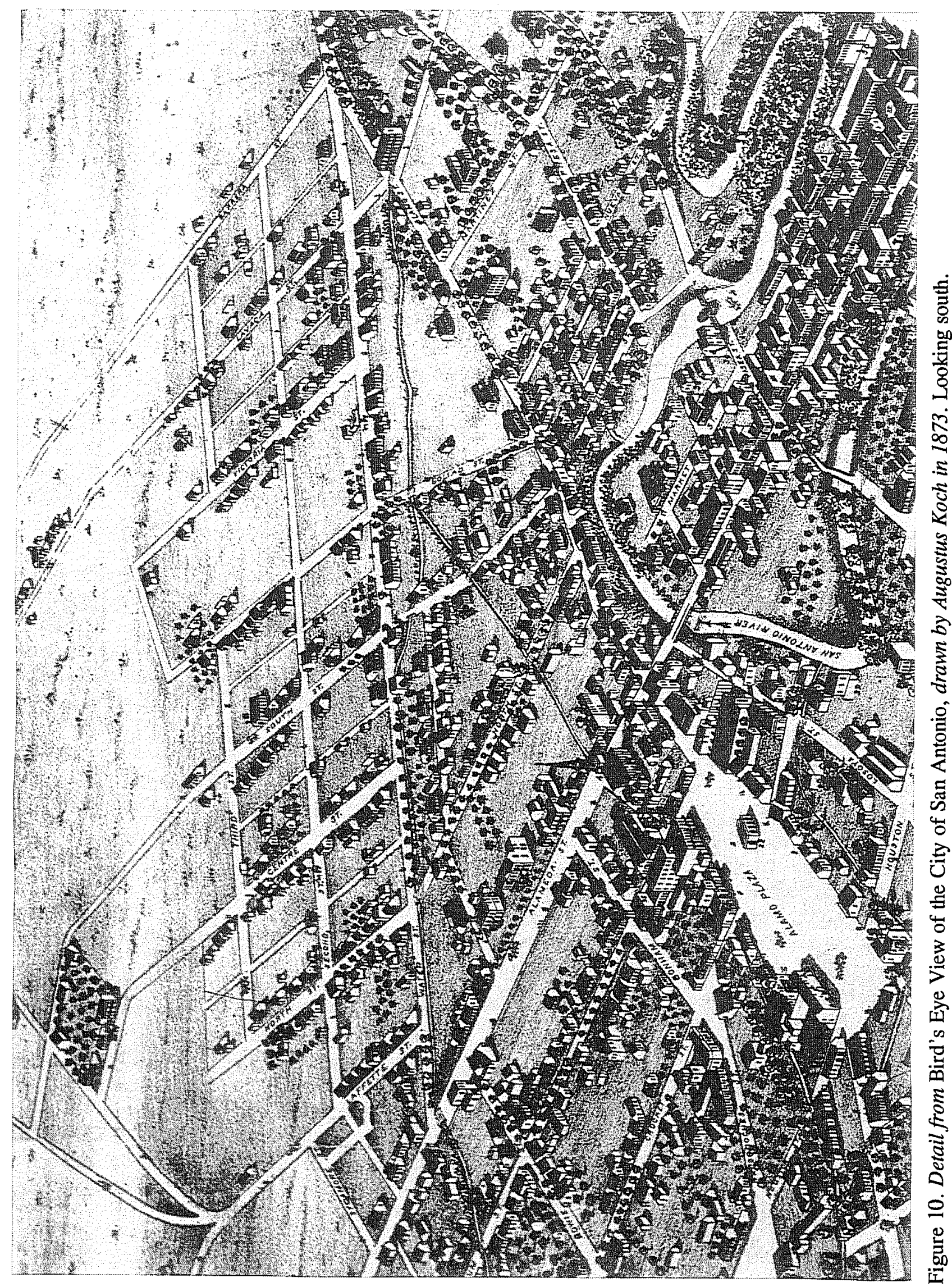




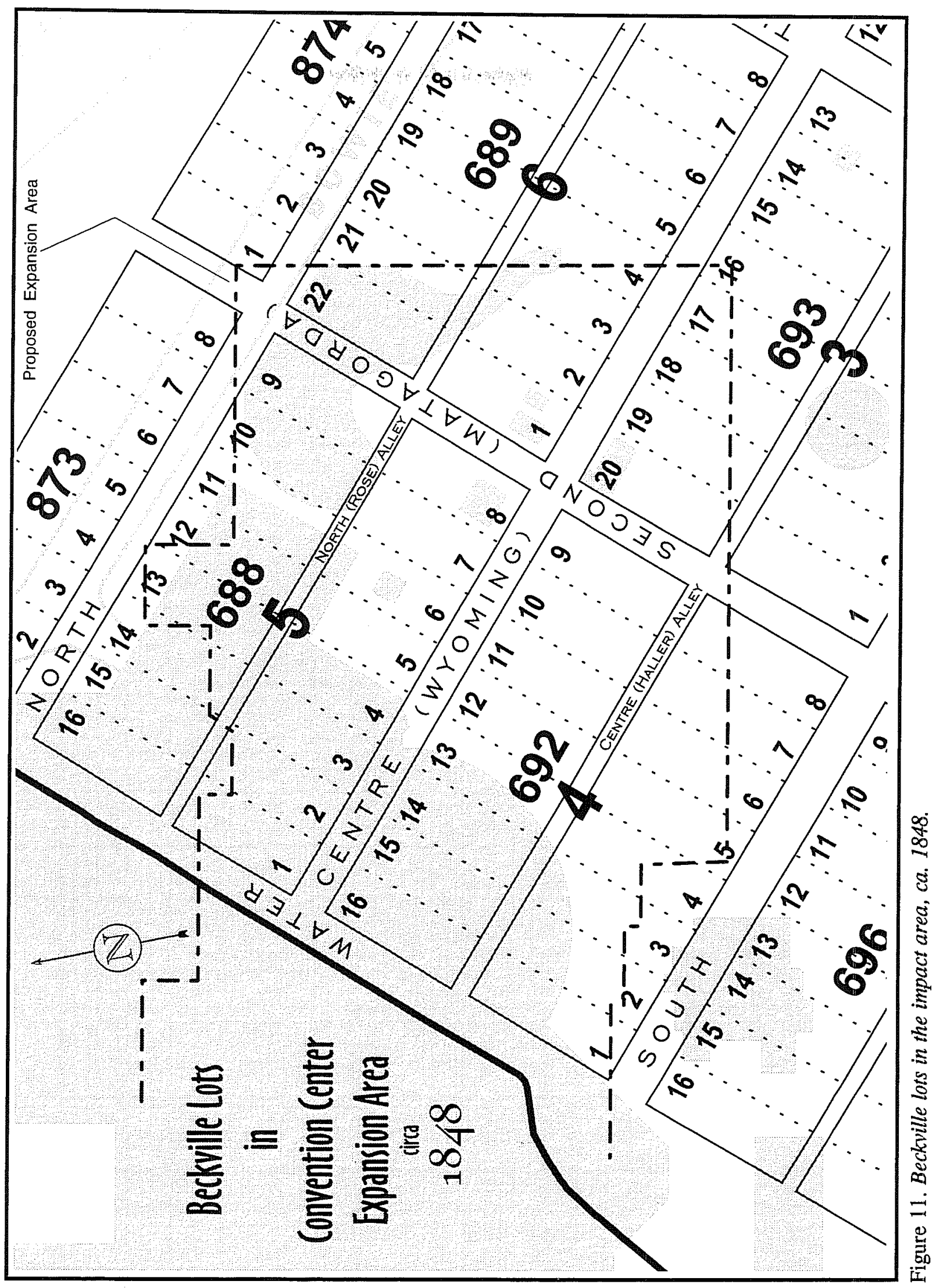




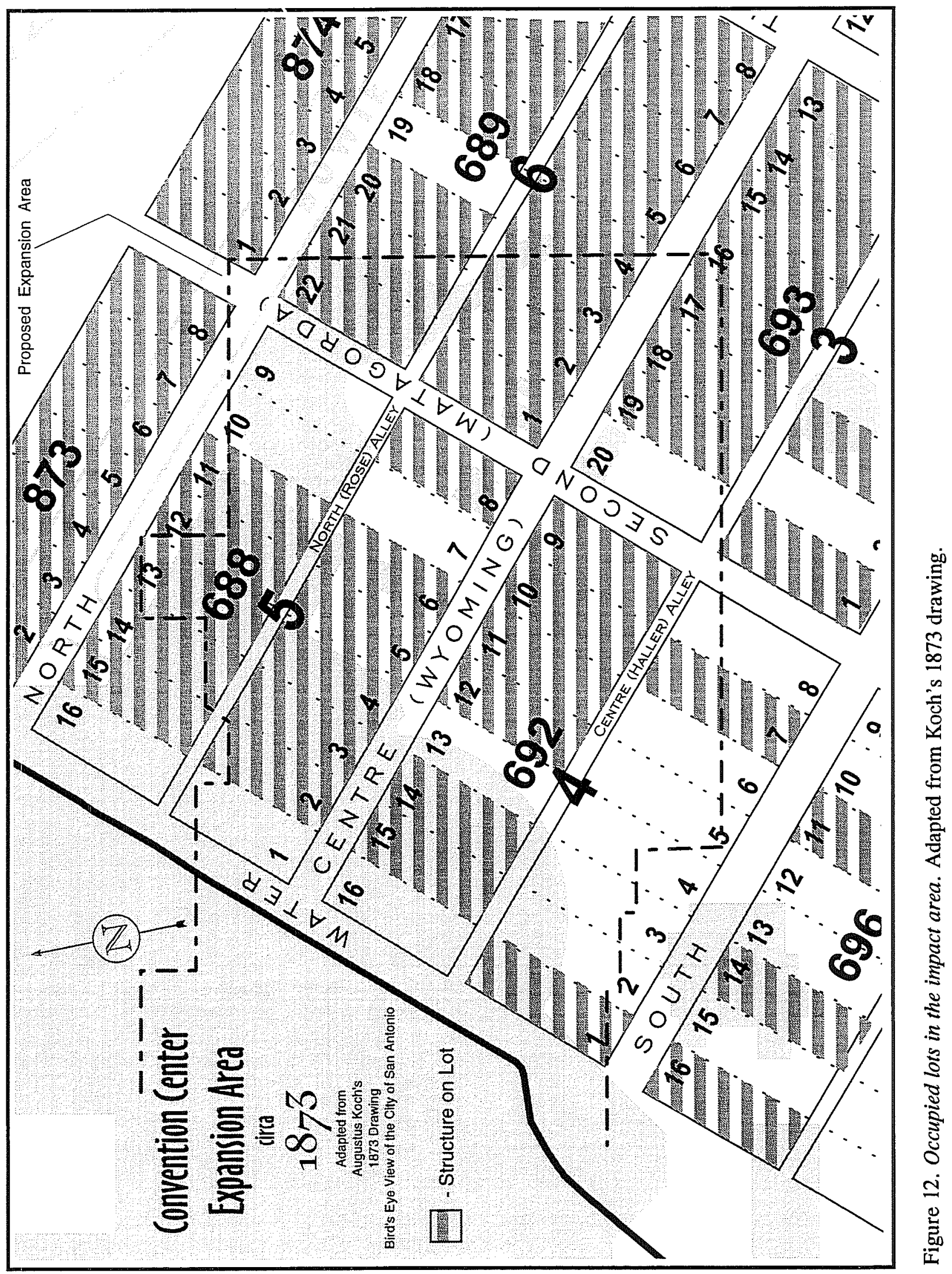




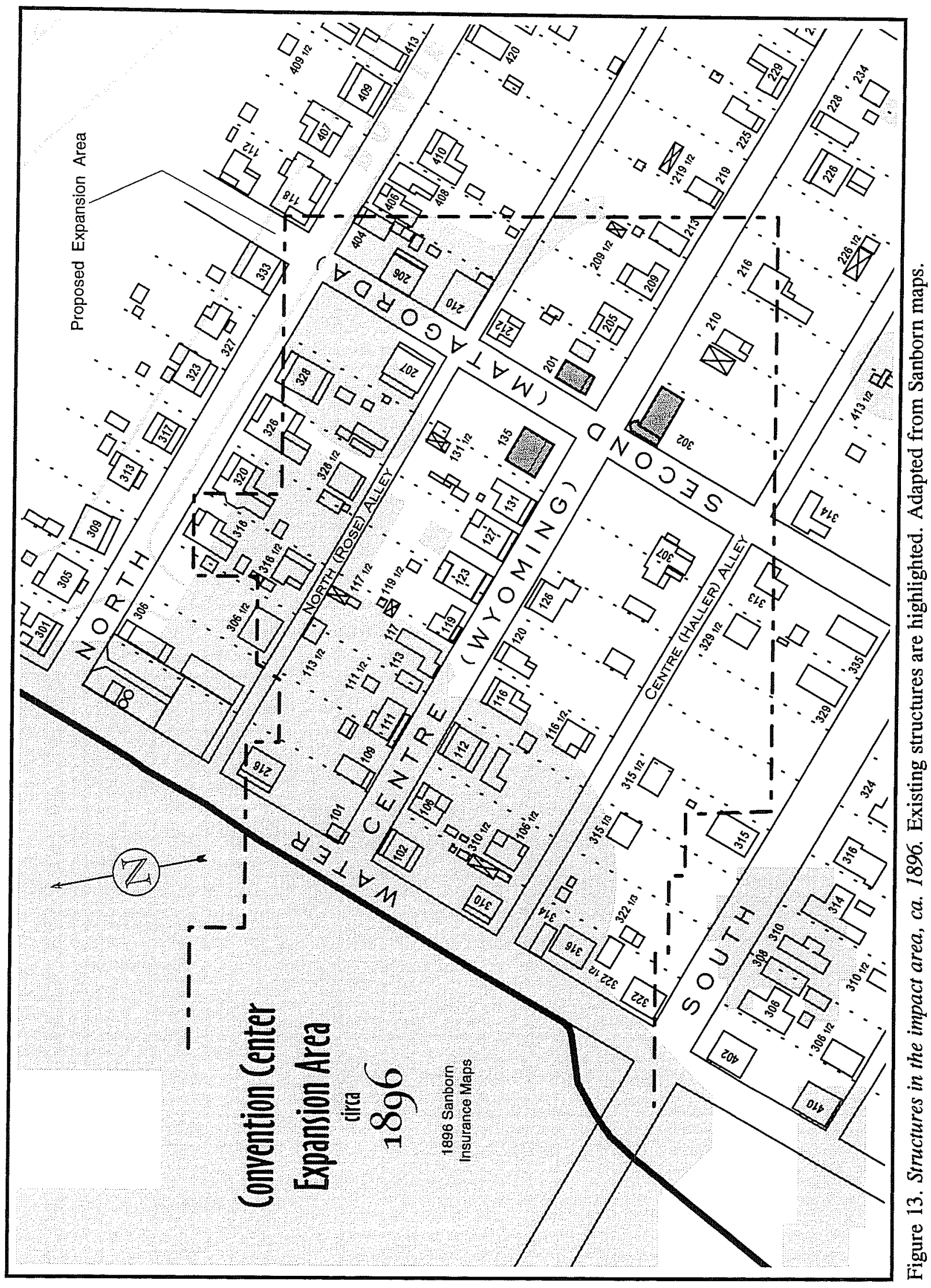




\section{Amaya House (Structure 201)}

The Amaya House (Figure 14) occupied the northeast corner of the intersection of Second and Centre streets (see Figure 13). Construction dates of some very small buildings, like the Amaya House, are sometimes hard to determine. Many small houses were not entered on tax rolls until the late-nineteenth century. Until then, many people in this area were taxed according to the number of livestock, rather than the actual property that they owned (SACSVF 25 ). Nevertheless, the lots are easily traced from Joseph Beck's initial sales.

In January 1859, Beck sold Lots 1 and 2 of Block 6 for $\$ 175$ to Walter C. Tynan (BCDR R2:525). Tynan quickly resold these parcels in August of the same year for \$225 to William Cuff (BCDR R1:553). Cuff kept the lots paired when he sold them in September 1865. The new owner, Carl Dobrowolski, bought the real estate for $\$ 300$ (BCDR T2:5).

Koch's drawing indicates that both lots had structures in 1873. This and previous deed transactions suggest that the Amaya House may have been built by Dobrowolski. The next transaction also supports this position. Carl Dobrowolski's sons, William and Edward, broke up the paired lots. They sold Lot 1 as

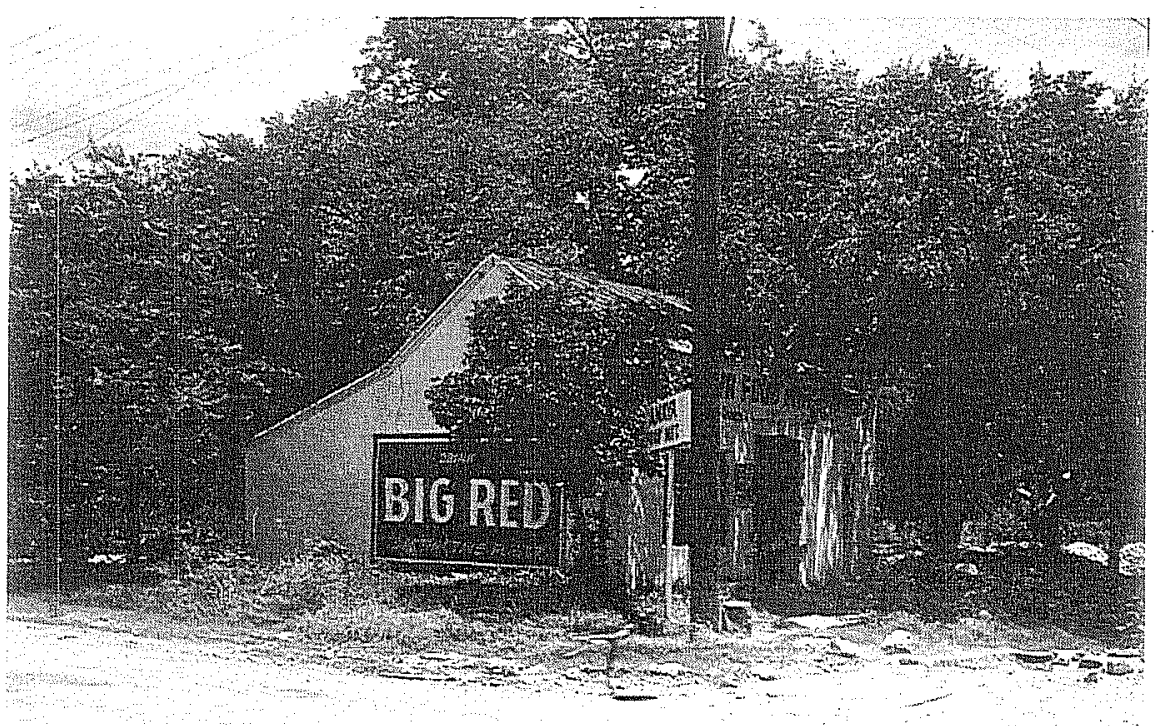

Figure 14. Amaya House, ca. 1966. 201 Wyoming (Centre), Beck Block 6, Lot 1, (ITC Photo 82-590). part of a two-tract transaction for $\$ 1,100$ to Blas Kulawik in March 1890 (BCDR 70:210). The city directory lists Kulawik's occupation as policeman (CD 1891). City directories also show that Lot 2 remained in the Dobrowolski family for at least the next 30 years.

Different renters occupied the Amaya house through the years. In 1929 it was the home of the Webber Linen Supply Company. Charles Amaya, a piano tuner, was the owner of the building in 1951. In 1955 he evidently practiced his trade there, that year the building was known as the Amaya Piano Repair Shop. By 1960 the named had changed to the Amaya Food Market. In 1965 all of the structures on the block between Matagorda and Indianola were vacant.

At the time of this report, the Amaya House is scheduled to be moved to Lot 1 of CB 889. Within the Historic Triangle, the new site is on the south side of Goliad Street, immediately northeast of the reconstructed section of the acequia and just south of the park's clock tower (see Figure 2). Cliff Croom, the current proprietor of the Amaya House, plans to keep the establishment after the move. Now known as the Amaya Deli and Yogurt House, the building will front Goliad Street after more than 120 years on Wyoming (Centre) Street. Another historic structure, the Smith House, presently stands just east of the new site.

The Smith House fronts Water Street. The original boundary for this tract was marked by Water Street on the east and the acequia to the west. As such, the new Amaya site is actually on the same lot as the Smith House. The Amaya house will now become the latest chapter in the Smith lot history.

John Riddle sold the property to Sam S. Smith in June 1857 for $\$ 175$ (BCDR P1:310). Smith kept the tract for just over a year before he sold it to Maria Dolores Delgado y Cantu and her husband Juan. One of the three oldest families in Bexar County, the Cantu family paid Smith $\$ 150$ for 
the real estate in November 1858 (BCDR R2:609). The next transfer occurred in 1895 when Luis Carvajal bought the property (SACSVF 31).

\section{Wietzel House (Structure 135)}

Lots 5-8 of Block 5 were originally sold together in one transaction. In July 1859 , Rochius Wozgsey paid Beck $\$ 308$ for all four tracts (BCDR R1:459). Located on the north side of Centre Street between Water and Second streets, these tracts were all eventually acquired by members of the Wietzel family. The last remaining structure now sits on Lot 8 and will be relocated to Goliad Street (see Figure 13).

Jacob Wietzel acquired Lots 7 and 8 from Rochius and Maria Wozgsey in April 1865 for $\$ 100$ (BCDR $\mathrm{T} 1: 388$ ). Given the relatively small amount of money paid for the two lots, the tracts were probably still undeveloped at the time. Koch's drawing shows a house on Lot 8 , the corner lot. Heading west, the drawing also shows a vacant lot and then two structures. This suggests that the structure on Lot 7 (131 Centre) was the last of the four to be built (Figure 15). All four houses are shown on the 1896 Sanborn Insurance Map (see Figure 13). In 1925, Charles A. Fischer acted as administrator for the Wietzel estate and guardian for Wietzel's minor children. Fischer sold several properties, including the four lots on what was then Wyoming Street. Mary and George F. Eckenroth and other members of the Wietzel family paid $\$ 3,500$ for the tracts (BCDR 834:616). Mary Eckenroth was the daughter of Mary Wietzel, and a later notation states that the property was part of her inheritance (BCDR 1337:455).

In 1933, Mary Eckenroth sold the Wyoming Street lots for $\$ 10$ and "other good and valuable considerations" to Theresa Rose Hochwater (BCDR 1337:455).
Mary had a sister named Theresa; this was probably she. The four lots were transferred again in 1944. Caroline Wietzel, in a deed of gift, gave the four lots to her widowed sister Elizabeth Gros (BCDR 2043:85).

The relocation site for the Wietzel House is one of 16 lots that Beck sold to Nicholas Longworth in August 1855. The lot was sold by the Longworth estate in June 1890 to Morris Friedman (BCDR N1:226, 64:375). Although there were houses all along the rest of the block, 1896 Sanborn maps indicate that this lot was empty (Figure 16). Around the same time the Longworth estate sold Lot 4 to Mary McAllister (BCDR 64:339). The McAllister name also appeared on Lot 5. Mrs. Ida Caroline McAllister purchased the parcel for $\$ 1,500$ from Morris and Sallie Friedman (BCDR 154:52).

S. Joe McAllister built a house here about 1896-1897. The fashionable home included ornamental brass door knobs, sliding doors, a steam heater, colored glass in a large bay window, and canvas ceilings hand-painted by Fred Donecker (SACSVF 39). The large house is shown on the 1904 Sanborn Map and city directories indicate that $S$. Joe McAllister resided at 319 Goliad Street from 1896

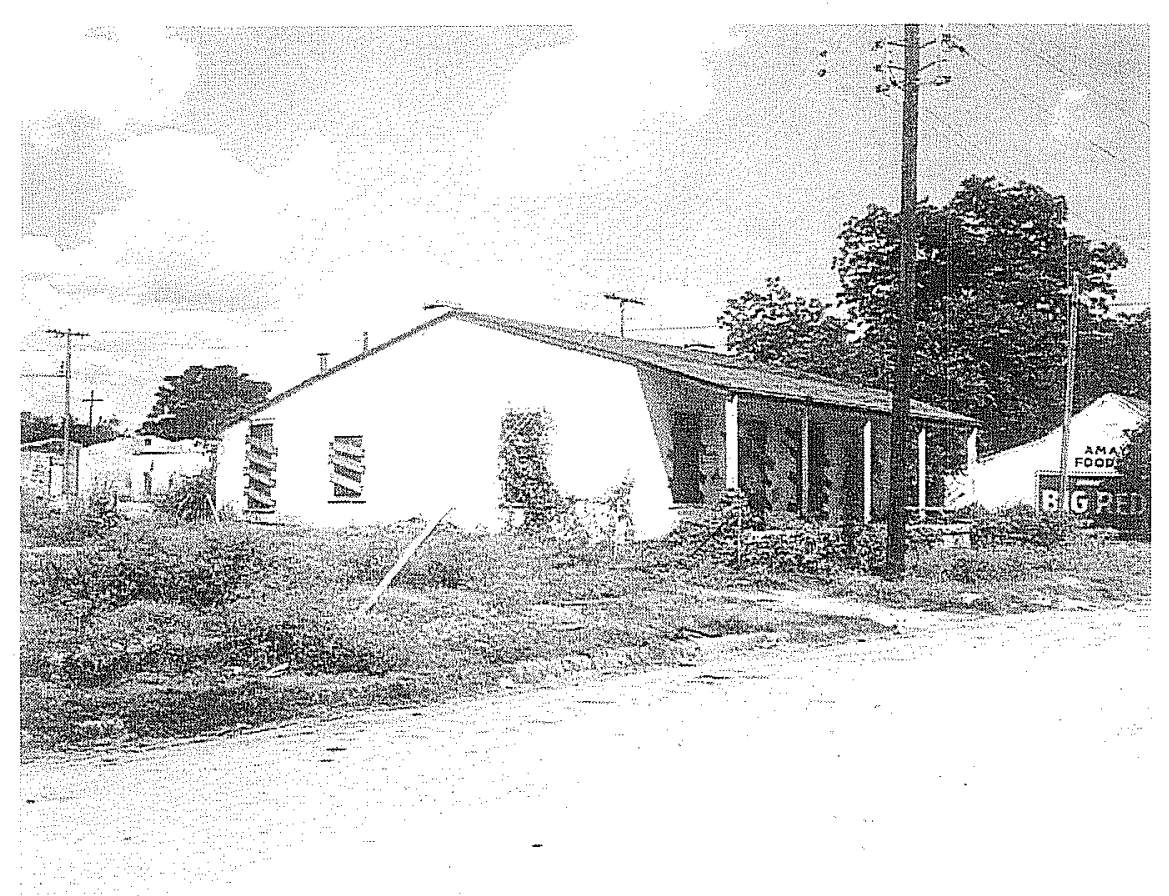

Figure 15. Wietzel House, ca. 1966. 135 Wyoming (Centre); Beck Block 5, Lot 8 (ITC Photo 82-582). 


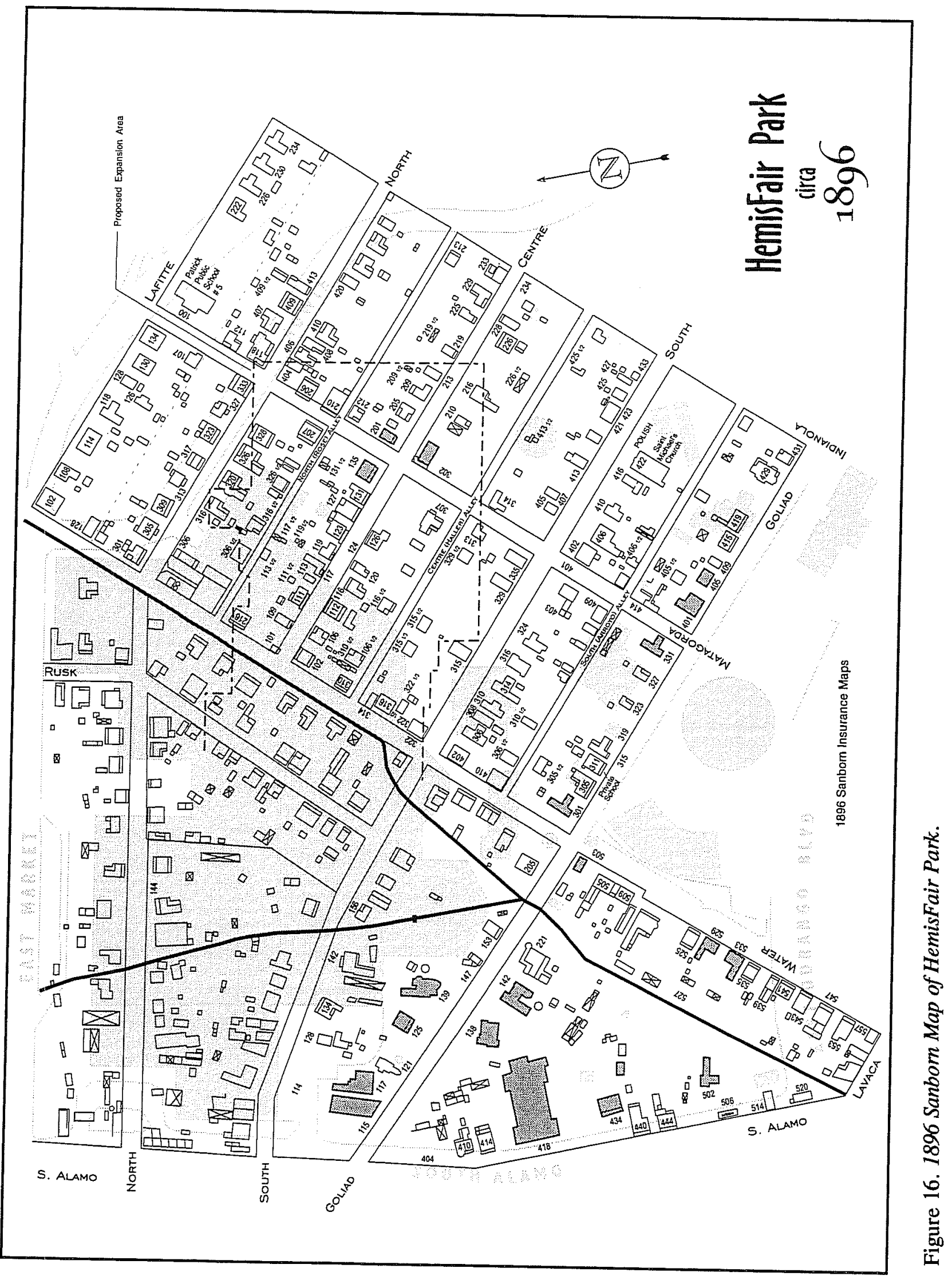


through 1919. The city began improvements along Goliad Street in 1915, grading and paving its entire length from South Alamo Street to Peach Street (BCDR 474:297). The house was demolished during the early part of the urban renewal project (SACSVF 39).

\section{O K Bar (Structure 302)}

As with all of the Beckville lots, the original boundary lines for Lots 19 and 20 were established with the Smythe survey (see Figures 9, 11, and 13). Block 3 had more than 16 lots because it included a fractional block just east of Third Street. The same condition existed for Blocks 2 and 6. Joseph Beck sold the O K Bar parcels to Nicholas Longworth in August 1855. The 2,000 square varas at this location only accounted for two of the 16 lots which Mr. Longworth purchased in the same transaction.

Like Beck, Nicholas Longworth was a land speculator. Although records indicate that he resided in Cincinnati, Ohio, Longworth paid Beck \$1,725 for 16 tracts on Centre, Goliad, North, and South streets (BCDR N1:226). All 16 lots remained in Nicholas Longworth's name until his death in 1890 . According to Koch, Lot 19 appears to have a house and attachment, but Lot 20 , on the southeast corner of Second and Centre streets, was vacant. In fact, in 1873 many of Beckville's vacant lots belonged to Longworth. Official deed records confirm the locations of Longworth's vacant parcels on Koch's drawing. In June 1890 administrators for the Longworth estate sold Lots 19 and 20 of Block 3 for $\$ 4,400$. Two additional lots on Centre Street were included in this exchange (BCDR 64:373). The new owner, George Dullnig, paid $\$ 1,100$ for each lot.

After he entered business in San Antonio in 1856, George Dullnig prospered in many enterprises. Besides his main pursuit as a grocery merchant, he was also a banker and railroad builder. The
Dullnig Ranch was located near the present site of Brooks Air Force Base, about six miles southeast of the city. While drilling for water, Dullnig struck oil in 1886. The 49 barrels of oil pumped from Dullnig's ranch was the first oil produced in Texas (Rybczyk 1992:227). Three years later and one year before this transaction, oil and gas from the Dullnig wells placed Texas in the United States government's petroleum statistic tables for the first time. In 1889 Texas became known as an oil-and gas-producing state due to the contributions of San Antonio, Bexar County, and George Dullnig (House 1968[1949]:158-159).

Dullnig sold Lots 19 and 20 in February 1892. Elimia Zizelmann purchased both lots for $\$ 3,000$ (BCDR 95:91). The 1896 Sanborn map (see Figure 13) shows a structure on Lot 20 that is likely the same structure that housed the $\mathrm{O} \mathrm{K}$ Bar (Figure 17). It also shows an attachment that may have been associated with the structure on Lot 19 . The 1913 city directory lists the O K Grocery and Market at 302 Matagorda Street. Because this was a corner lot, the 1919 directory lists 302 Matagorda as the O K Grocery and 204 Wyoming as the O K Bar (CD 1913, 1919).

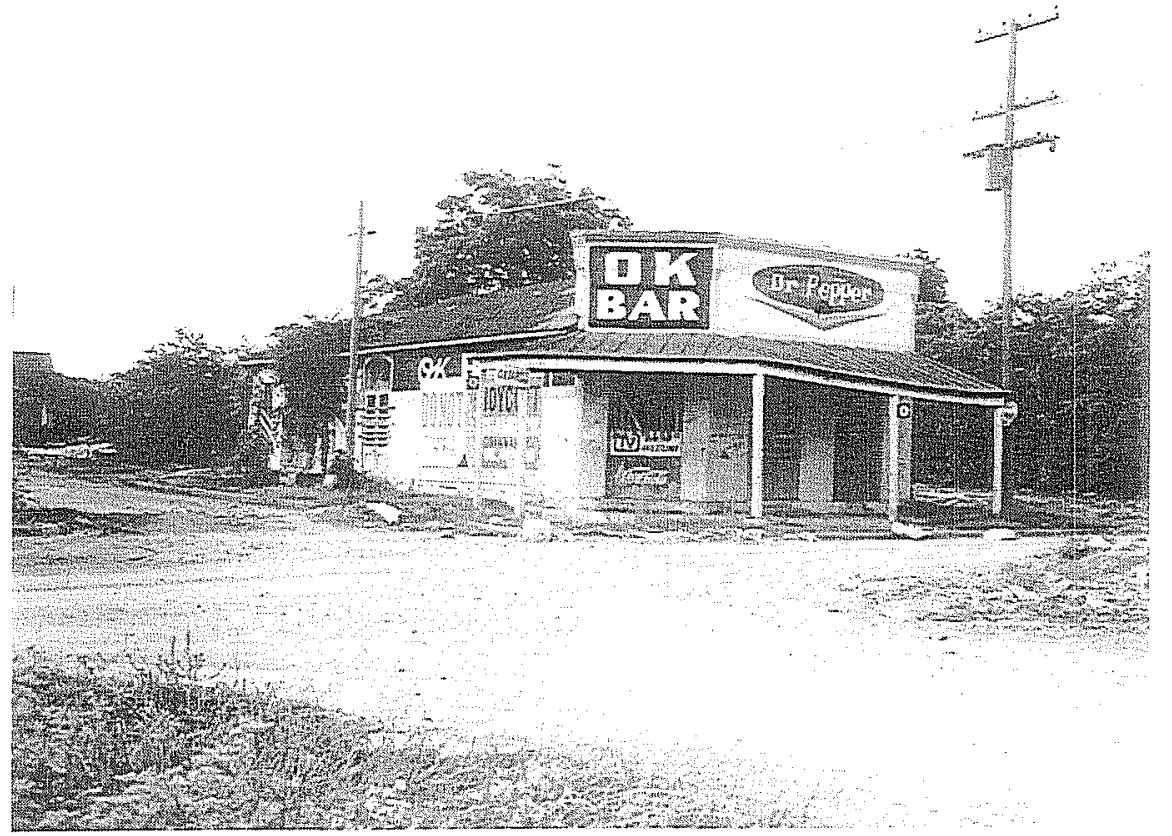

Figure 17. O K Bar, ca. 1966. 204 Wyoming (Centre), 302 Matagorda (Second); Beck Block 3, Lots 19 and 20 (ITC Photo 82-585). 
The new location for the $\mathrm{OK} \mathrm{Bar}$ is just south of the R. M. Pereida House in the Historic Triangle (see Figure 2). In fact the Pereidas once owned the land. His neighbor to the immediate south on Alamo Street, Pedro Cabrera, sold Pereida the lot in 1890 (BCDR 76:432). The 1896 Sanborn Map shows a small structure just south of the Pereida House, and the 1896 Sanborn indicated that it was an adobe (cut caliche block) building (see Figure 16). The foundation for this structure was probably destroyed when South Alamo Street was widened in 1929 (BCDR 1095:114). The 1904 Sanborn Map clearly shows a large house at 508 South Alamo Street on Lot 14, but the structure is not shown on the 1896 Sanborn Map. Therefore the large structure must have been built sometime between 1896 and 1904 . Barbara Bosshardt purchased the lot from Pereida for $\$ 1,200$ in January 1904 (BCDR 226:341). City directories from 1905 and 1907 list Miss Bosshardt as the owner at 506 S. Alamo Street (CD 1905, 1907), however, the lot was actually resold again in 1906. Charlotte J. Hewitt made a down payment of $\$ 1,800$ cash towards the total $\$ 4,200$ price in November 1906 (BCDR 248:527). Ownership of the property then changed hands again in 1913 when Clara J. Winlack paid Miss Bosshardt $\$ 4,500$ for the deed (BCDR 259:99). Clara Winlack subsequently turned over the property to L. F. Birdsong for $\$ 6,000$ in 1915 (BCDR 462:190). The city directory still listed the Birdsongs as the owners in 1919. By 1951 the site had become a lot for J. Gordon Cottingham's used cars (CD 1951).

\section{Vacant Lots}

The following tables and narratives highlight early histories of now-vacant lots in the Convention Center expansion area. Due to the nature of their construction, the old arena and parking garage have relatively deep foundations. Lots in these areas certainly have been totally destroyed by HemisFair construction during the 1960s. This is especially true in the case of the arena footprint where part of the structure extends below the surface. Therefore, these tracts are mentioned but not discussed in detail. Another modern feature in the construction area is an artificial lake.
One of the many attractions at HemisFair '68 was a specially constructed waterway that meandered through the fair grounds. Large fountains of bubbling water still entice visitors to HemisFair Park. Part of this waterway is located in the northeast section of the construction area. The lake, shown in Figure 2 and dimmed in Figures 11, 12, and 13, extends across CB 688 and CB 689. Although the lake's foundation is deeper than those of the historic structures and other empty lots, it is not as deep as the arena or parking garage. Lots in the lake area are discussed with other empty tracts. Vacant lots discussed in this section include 5, 6, 7, 9, and 10 from $\mathrm{CB}$ 688; Lots 3, 4, 21, and 22 in CB 689; Lots 4-12 in CB 692; and Lots 17 and 18 in CB 693.

Broken down by block, each table shows the initial transfer of selected town lots from Joseph Beck. The tables also include the lot's sales price and indicates if more than one lot was included in the transaction. Most early deed records do not state if the lot was occupied or unimproved. However, in the absence of more definitive information, a comparison of sales prices can provide clues about the lot's status. Some noted individuals and families will be recognized from the lists of grantors and grantees. A more comprehensive table of Beckville transactions is given in Appendix B.

\section{City Block 688, Beck Block 5}

\section{Lots 1-4 and 11-14}

These parcels fall within the area of the demolished arena and parking garage. They were destroyed by HemisFair construction.

\section{Lots 5, 6, and 7}

The 1952 Sanborn Map shows that the original Beckville lot boundaries had changed. No longer uniform in size, the four Wietzel structures were counted on only three of the eight numbered lots. The original four lot boundaries would have included 119 , 123, 127, 131, and 135 Wyoming Street. San Antonio's 1951 city directory shows that Mrs. Dora Jackson owned the house at 135, Raymond R. Hochwater at 131, Bernard Gros at 127 (Figure 18), 
Frank Toudouze at 123 , and Cecelia Wietzel at 119 Wyoming Street (see Figure 13). They were among the last owners or occupants of the properties before HemisFair's urban renewal project. The Toudouze family resided here for more than 40 years (CD 1919-1920 to 1960). Although many residents willingly moved from the project area, Mr. Toudouze and his family exemplified some of the emotional scars caused by the urban renewal plan. In order to evict Frank Toudouze and his wife, law enforcement officials broke a lock and smashed down the door at 123 Wyoming, on April 6, 1966. They were the last holdouts (SAE 28 March 1993).

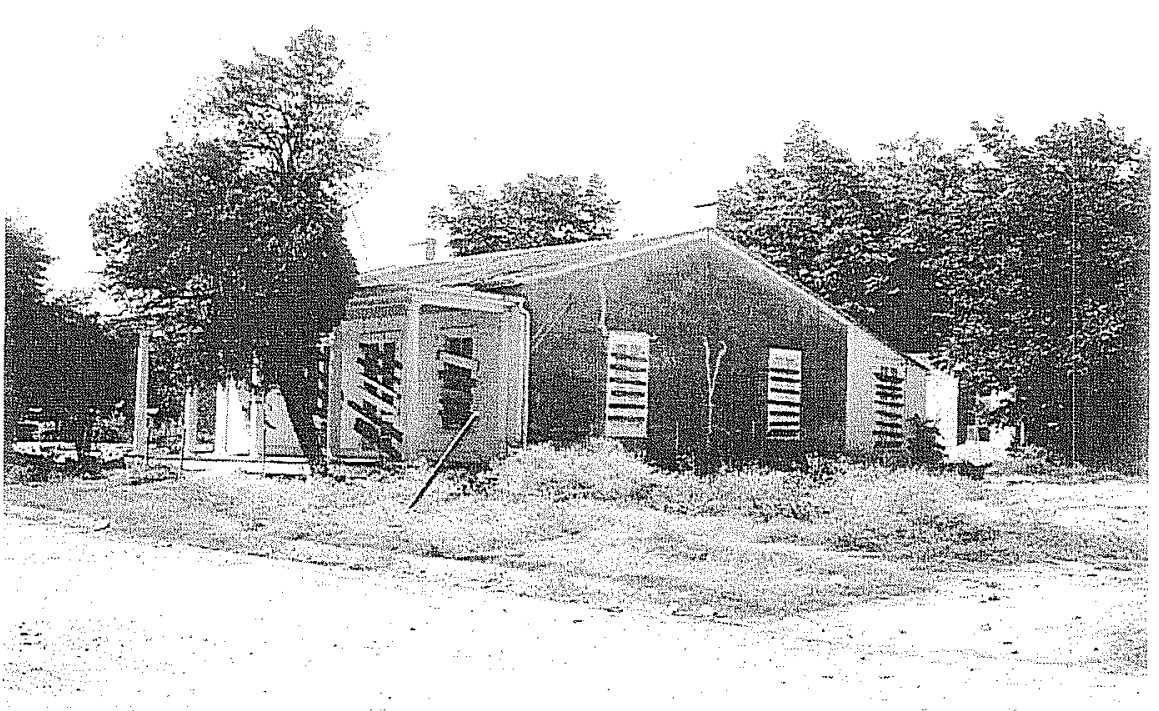

\section{Lots 9 and 10 (Table 4)}

Figure 18. Gros House, ca. 1966. 127 Wyoming (Centre); CB 688, Beck Block 5, Lot 6 (ITC photo 82-58).

These lots are located under the footprint of the artificial lake in the project area. Koch's drawing shows that Lots 9 and 10 were two of the few lots in the construction area that were unoccupied in 1873 (see Figure 12). Joseph Beck sold Lot 9 to Joseph
Hubner in 1856 and Lot 10 to Thomas Mc Dermott in 1854 (BCDR 01:467, M2:263). Both lots eventually became the property of Phillip Bitter. In March 1867, Bitter sold the property to August Reeb. Bitter and Reeb originally resided in New Braunfels, Comal

Table 4. Beck Block 5, CB 688

\begin{tabular}{|c|c|c|l|l|l|l||}
\hline Lot & \multicolumn{1}{|c|}{ Date } & \multicolumn{1}{|c|}{$\$$} & \multicolumn{1}{|c|}{ Grantor } & \multicolumn{1}{|c|}{ Grantee } & \multicolumn{1}{|c|}{ Note } & \multicolumn{1}{|c|}{ BCDR } \\
\hline 09 & $10 / 7 / 1856$ & 75 & Beck, Joseph H. & Hubner, Joseph & O1:467 \\
\hline 09 & $5 / 25 / 1857$ & 100 & Hubner, Joseph & Altmann, Anton & O2:231 \\
\hline 09 & $9 / 27 / 1859$ & 125 & Altmann, Anton & Bitter, Phillip & R1:598 \\
\hline 09 & $3 / 16 / 1867$ & 400 & Bitter, Phillip (New Braunfels) & Reeb, August (New Braunfels) & 1 of 2 lots & U1:358 \\
\hline 10 & $9 / 8 / 1854$ & 225 & Beck, Joseph H. & Mc Dermott, Thomas & 1 of 2 lots & M2:263 \\
\hline 10 & $6 / 23 / 1856$ & 250 & Mc Dermott, Thomas & Lasterie, James & 1 of 2 lots & O1:199 \\
\hline 10 & $12 / 20 / 1856$ & 210 & Lasterie, James & Richards, Jacob B. & 1 of 2 lots & P1:178 \\
\hline 10 & $7 / 24 / 1858$ & 300 & Richards, Jacob B. \& Margaret & Harris, Samuel & 1 of 2 lots & R2:117 \\
\hline 10 & $5 / 5 / 1859$ & 180 & Harris, Samuel & Wilkins, John & R1:369 \\
\hline 10 & $3 / 16 / 1867$ & 400 & Bitter, Phillip (New Braunfels) & Reeb, August (New Braunfels) & 2 of 2 lots & U1:358 \\
\hline 10 & $4 / 10 / 1872$ & $900 ?$ & Reeb, August & Bitter, Wilhelm & & W1:539 \\
\hline
\end{tabular}


County, Texas (BCDR U1:358). The Balderas Grocery and Food Market was located on Lot 9 near the intersection on North and Matagorda streets from 1950 to 1960 (CD).

\section{City Block 689, Beck Block 6 (Table 5)}

\section{Lots 3 and 4}

A section of the lake cuts a small path through the north side of Lot 3 and slightly intrudes into Lot 4 (see Figure 11). These tracts are just east of the two parcels associated with the Amaya House. Emil Abat purchased eight lots from Beck in February 1859 for $\$ 376$. Lots 3 and 4 were two of those tracts (BCDR $\mathrm{R} 1$ :223). Abat sold all eight lots in July of the same year to Paul Maureaux for $\$ 480$ (BCDR R1:476). The set of eight parcels was split when John $M$. McConnell purchased four contiguous tracts on Block 6 for $\$ 400$. Maureaux sold him Lots 3, 4, 5, and 6 in February 1860 (BCDR H2:242). Still in the same year, McConnell transferred Lot 4 to Henreich Fuhrmeister for $\$ 110$ in March.

McConnell kept Lot 3 until April 1860. At that time John Murphy paid McConnell $\$ 117$ for the tract (BCDR S1:217). Deed records suggest that Murphy

Table 5. Beck Block 6, CB 689

\begin{tabular}{|c|c|c|c|c|c|c|}
\hline$\overline{\text { Lot }}$ & Date & $\$$ & Grantor & Grantee & Notes & BCDR \\
\hline 03 & $2 / 2 / 1859$ & 376 & Beck, Joseph H. & Abat, Emil & 5 of 8 lots & $\mathrm{R} 1: 223$ \\
\hline 03 & $7 / 25 / 1859$ & 480 & Abat, Emil & Maureaux, Paul & 5 of 8 lots & $\mathrm{R} 1: 476$ \\
\hline 03 & $2 / 11 / 1860$ & 400 & Maureaux, Paul & McConnell, John M. & 1 of 4 lots & $\mathrm{H} 2: 242$ \\
\hline 03 & $4 / 20 / 1860$ & 117 & McConnell, John & Murphy, John & 1 of 2 lots & S1:217 \\
\hline 03 & $4 / 20 / 1860$ & 117 & McConnell, John & Murphy, John & 2 of 2 lots & $\$ 1: 217$ \\
\hline 03 & $12 / 17 / 1860$ & 550 & Murphy, John \& Catherine & Cassidy, Miles & & $S 1: 539$ \\
\hline 04 & $2 / 2 / 1859$ & 376 & Beck, Joseph H. & Abat, Emil & 6 of 8 lots & $\mathrm{R} 1: 223$ \\
\hline 04 & $7 / 25 / 1859$ & 480 & Abat, Emil & Maureaux, Paul & 6 of 8 lots & $\mathrm{R} 1: 476$ \\
\hline 04 & $2 / 11 / 1860$ & 400 & Maureaux, Paul & McConnell, John M. & 2 of 4 lots & $\mathrm{H} 2: 242$ \\
\hline 04 & $3 / 26 / 1860$ & 110 & McConnell, John & Fuhrmeister, Henreich & & $\mathrm{H} 2: 244$ \\
\hline 20 & $8 / 13 / 1855$ & 1725 & Beck, Joseph H. & Longworth, Nicholas & 16 of 16 lots & $\mathrm{N} 1: 226$ \\
\hline 20 & $7 / 10 / 1890$ & 1400 & Longworth, Nicholas (estate) & $\begin{array}{l}\text { Shook, John R. and } \\
\text { F. F. Vanden Haenen }\end{array}$ & 2 of 2 lots & $71: 181$ \\
\hline 21 & $1 / 23 / 1854$ & 58 & Beck, Joseph H. & Brackett. A.B. & & L2:213 \\
\hline 21 & $3 / 14 / 1855$ & 198 & Beck, Joseph H. & Smith, Sam S. & 3 of 3 lots & M2:639 \\
\hline 21 & $1 / 3 / 1863$ & 750 & Smith, Sam S. & Wurzbach, Francis & 3 of 3 lots & $S 2: 504$ \\
\hline 21 & $4 / 28 / 1866$ & 250 & Wurzbach, Francis & Dugosh, Albert & & $\mathrm{U} 1: 31$ \\
\hline 21 & $5 / 10 / 1866$ & 250 & Dugosh, Albert & Kotula, Francis & & $\mathrm{T} 2: 745$ \\
\hline 21 & $12 / 13 / 1870$ & 600 & Kotula, Elizabeth & Kotula, Ferdinand $\mathrm{C}$. & $\begin{array}{l}\text { witnessed by } \\
\text { Theo Baldus }\end{array}$ & $\mathrm{V} 1: 567$ \\
\hline 22 & $3 / 1855$ & 164 & Beck, Joseph H. & Taylor, $\mathrm{H}$. & 2 of 2 lots & G2:379 \\
\hline 22 & $1 / 10 / 1856$ & 100 & Taylor, P.C. & Cuff, William & & $\mathrm{N} 2: 156$ \\
\hline
\end{tabular}


and his wife Catherine constructed a home on the lot and quickly resold the property. Eight months after they purchased Lot 3, the Murphys sold the single tract for $\$ 550$ in December (BCDR S1:539). Koch shows that structures filled the entire block in 1873 (see Figure 10).

William Berndt, a sausage maker, owned the house on Lot 3 in 1877 and was still there in 1891. His nextdoor neighbors, the Fuhrmeisters, were still on Lot 4 where they remained until 1891. Henry Fuhrmeister's occupation was listed as groceries and saloon, while Herman was a driver for the Waters, Pierce Oil Company. C. M. and Mary Gabbart later purchased the property where they established C. M. Gabbart and Company.

\section{Lots 21 and 22}

Construction of the lake impacted about half of Lot 21 and nearly all of Lot 22 (see Figure 11). Early deed records show that Sam S. Smith purchased Lot 21 from Joseph Beck in March 1855 (BCDR M2:639). Subsequent owners of this lot included other notable and familiar San Antonio family names. Among them were Albert Dugosh in 1866 and the Kotulas in 1870.

Beck sold Lot 22 (see Figure 11) to H. Taylor the same month that Lot 21 was sold to Sam Smith (BCDR G2:379). The Taylor family held Lot 22 for less than a year. William Cuff became the new owner in January 1856 (BCDR N2:156). In more contemporary times, this corner lot was the home of different tortilla-manufacturing establishments. In 1950 it was Duran's Place, in 1955 the Pan-American Tortilleria, and finally El Sombrero Tapatio Tortillas in 1960 (CD).

\section{City Block 692, Beck Block 4 (Table 6)}

\section{Lots 1-3 and 13-16}

The northern section of Lots 1,2 , and 3 are located in the construction area of the HemisFair arena (see Figure 11). Likewise, the western half of Lot 13 and all of Lots 14, 15, and 16 were impacted by subsurface construction.
Lots $4-8$

The original owners and early residents of these lots are listed in Table 6. By the turn of the century some of these tracts were being used as rental properties. Of the seven structures listed on these lots in 1918, only the house on Lot 7 was occupied by its owners. E. M. and Julia Thomas (see Figure 11). All the other structures were occupied by tenants (CD 1919-1920). In time new owners did acquire some properties, but for the most part these lots changed renters many times. City directories also indicate that these tracts were always residential homes. None of the lots was referred to as a business establishment.

\section{Lots 9 and 10}

Located on the south side of Centre Street, the early histories of these two parcels are identical to the lots of the OK Bar (see Figure 11). Lots 9 and 10 were two of the 16 which Beck sold to Longworth in 1855 (BCDR N1:226). A house and attachment occupies the southern half of Lots 19 and 20 in Koch's 1973 drawing (see Figures 10 and 12). The same illustration also shows that the northern halves of these lots were vacant along Centre Street. The address for the structure was 307 Matagorda Street. It was also later listed as 135 Haller Alley (see Figure 13). George Dullnig purchased these lots and buildings in 1890 from the Longworth estate as part of the four lot transaction that included the O K Bar (BCDR 64:373). The 1896 Sanborn Map shows the house on 307 Matagorda on Lot 9 and a small structure in back on Lot 10 (see Figure 13).

\section{Lot 11}

This parcel was occupied in 1873 and its structure fronted Centre Street (see Figure 12). The house listed as 126 Centre Street in 1896 actually sits on parts of Lot 11 and 12 (see Figure 13). Like many buildings in this area, 126 Wyoming was already occupied by a tenant around the turn of the century. Jacob Wurz rented the property in 1902 (CD 1903-1904). 
Table 6. Beck Block 4, CB 692

\begin{tabular}{|c|c|c|c|c|c|c|}
\hline Lot & Date & $\$$ & Grantor & Grantee & Notes & BCDR \\
\hline 01 & $12 / 26 / 1856$ & 220 & Beck, Joseph H. & Schrier, Anton & 1 of 2 lots & $\mathrm{P} 1: 276$ \\
\hline 01 & $1 / 18 / 1858$ & 110 & Schrier, Anton & Weikzonack, Frantz & 1 of 2 lots $s$ half & $\mathrm{P} 2: 520$ \\
\hline 01 & $9 / 2 / 1863$ & 250 & Wyglendalz, Anton & Weikzonack, Barbara & 1 of 4 lots $n$ half & $\mathrm{T} 1: 26$ \\
\hline 02 & $12 / 26 / 1856$ & 220 & Beck, Joseph H. & Schrier, Anton & 2 of 2 lots & P1:276 \\
\hline 02 & $1 / 18 / 1858$ & 110 & Schrier, Anton & Weikzonack, Frantz & 2 of 2 lots $s$ half & P2:520 \\
\hline 02 & $9 / 2 / 1863$ & 250 & Wyglendalz, Anton & Weikzonack, Barbara & 2 of 4 lots $n$ half & $\mathrm{T} 1: 26$ \\
\hline 03 & $3 / 8 / 1859$ & 75 & Beck, Joseph H. & Wyglendalz, Anton & 1 of 2 lots & $\mathrm{H} 2: 75$ \\
\hline 03 & $9 / 2 / 1863$ & 250 & Wyglendalz, Anton & Weikzonack, Barbara & 3 of 4 lots $n$ half & $\mathrm{T} 1: 26$ \\
\hline 04 & $3 / 8 / 1859$ & 75 & Beck, Joseph H. & Wyglendalz, Anton & 2 of 2 lots & $\mathrm{H} 2: 75$ \\
\hline 04 & $9 / 2 / 1863$ & 250 & Wyglendalz, Anton & Weikzonack, Barbara & 4 of 4 lots $n$ half & $\mathrm{T} 1: 26$ \\
\hline 05 & $8 / 13 / 1855$ & 1725 & Beck, Joseph H. & Longworth, Nicholas & 11 of 16 lots & $\mathrm{N} 1: 226$ \\
\hline 05 & $7 / 18 / 1890$ & 2700 & Longworth, Nicholas (estate) & Steinhardt, Adolph & 2 of 3 lots & $72: 484$ \\
\hline 06 & $8 / 13 / 1855$ & 1725 & Beck, Joseph H. & Longworth, Nicholas & 12 of 16 lots & $\mathrm{N} 1: 226$ \\
\hline 06 & $7 / 18 / 1890$ & 2700 & Longworth, Nicholas (estate) & Steinhardt, Adolph & 3 of 3 lots & $72: 484$ \\
\hline 07 & $12 / 22 / 1859$ & 160 & Beck, Joseph H. & Moodie, John & 1 of 2 lots & S1:140 \\
\hline 07 & $9 / 10 / 1860$ & 115 & Moodie, John & Randziora, Vincent & & S1:416 \\
\hline 08 & $12 / 22 / 1859$ & 160 & Beck, Joseph H. & Moodie, John & 2 of 2 lots & S1:140 \\
\hline 08 & $11 / 12 / 1860$ & 125 & Moodie, John & Zyzik, Isidor & & $\mathrm{H} 2: 605$ \\
\hline 09 & $8 / 13 / 1855$ & 1725 & Beck, Joseph H. & Longworth, Nicholas & 13 of 16 lots & $\mathrm{N} 1: 226$ \\
\hline 09 & $6 / 26 / 1890$ & 4400 & Longworth, Nicholas (estate) & Dullnig, George & 3 of 4 lots & $64: 373$ \\
\hline 09 & $11 / 11 / 1890$ & 1500 & Dullnig, George & McAllister, Ida C. & 1 of 2 lots & $85: 120$ \\
\hline 10 & $8 / 13 / 1855$ & 1725 & Beck, Joseph H. & Longworth, Nicholas & 14 of 16 lots & $\mathrm{N} 1: 226$ \\
\hline 10 & $6 / 26 / 1890$ & 4400 & Longworth, Nicholas (estate) & Dullnig, George & 4 of 4 lots & $64: 373$ \\
\hline 10 & $11 / 11 / 1890$ & 1500 & Dullnig, George & McAllister, Ida C. & 2 of 2 lots & $85: 120$ \\
\hline 11 & $7 / 11 / 1859$ & 75 & Beck, Joseph H. & Achterberg, Frederick & & $\mathrm{H} 2: 151$ \\
\hline 11 & $2 / 9 / 1865$ & 500 & Achterberg, Frederick & Rudeman, Magdalene & & $\mathrm{T} 2: 684$ \\
\hline 12 & $4 / 12 / 1859$ & 75 & Beck, Joseph H. & Bohn, William & & $S 2: 223$ \\
\hline 13 & $3 / 5 / 1859$ & 130 & Beck, Joseph H. & Cush, John & 1 of 2 lots & $\mathrm{S} 1: 517$ \\
\hline
\end{tabular}

\section{Lot 12 (Figures 19 and 20)}

Although Koch shows a structure on this lot in 1873 (see Figures 10 and 12), the 1896 Sanborn Map (see Figure 13) shows that the buildings present at the time of HemisFair were not built until after 1896. The structures at 124 Centre Street sat between 120 and 126 Centre Street and is not shown until the 1904 Sanborn Map. This one-story limestone home and a building in the rear were both demolished to make room for HemisFair. 
Figure 19. 124 Wyoming Street, ca. 1966. CB 692; Beck Block 4, Lot 12. Demolished. (ITC Photo 82-580).

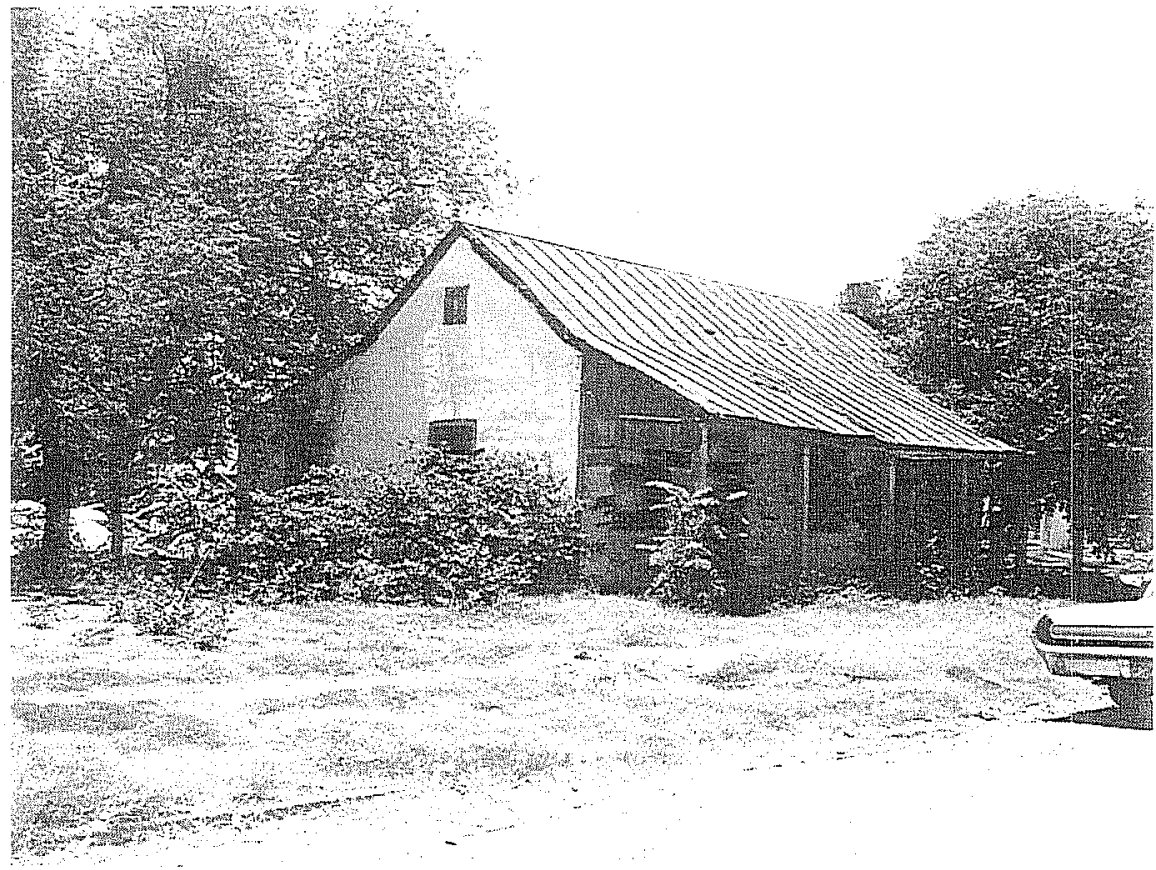

Figure 20. 124 Wyoming Street, ca. 1966. CB 692; Beck Block 4, Lot 12. Rear building, demolished. (ITC Photo 82-589).

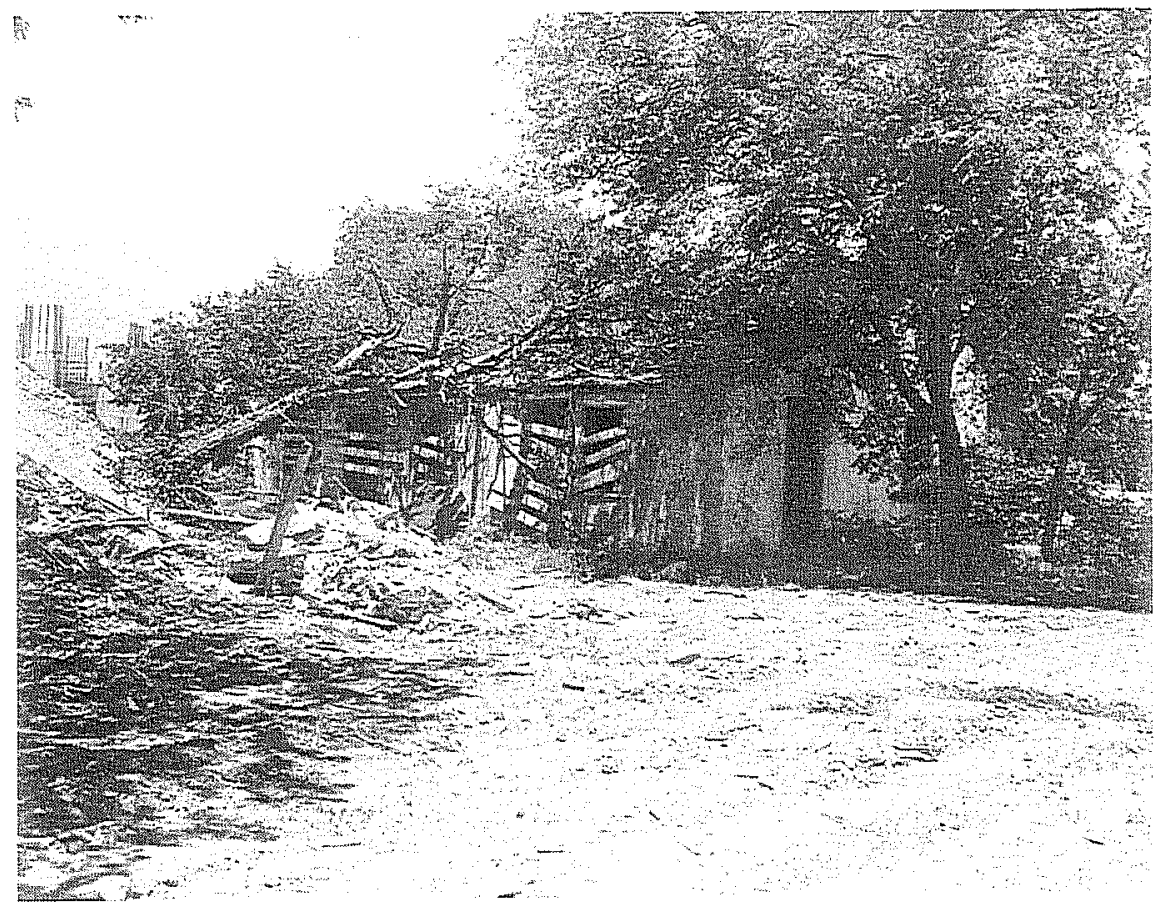
City Block 693, Beck Block
3 (Table 7)

\section{Lots 17 and 18}

Table 7 shows that both of these lots have the same early history. Both tracts had structures by 1873 (see Figures 11 and 12). In 1896 the addresses at Lots 17 and 18 were 216 and 210 Centre Street respectively (see Figure 13). Following the trend of the time, both structures were occupied by tenants in 1902. While 210 Wyoming Street became the longtime residence of a single family, 216 Wyoming was transformed into a church.

In 1912, Mrs. Pauline Rilling owned and lived on the property at on Lot 18. She remained at 210 Wyoming Street until at least 1951 (CD 1913-1951). By 1918, the structure on Lot 17 had become a Jewish Temple. The 1929-1930 city directory lists this address as "Congregation Rodfel Sholom B'Nai Israel." 
Table 7. Beck Block 3, CB 693

\begin{tabular}{|c|c|c|l|l|l|c||}
\hline Lot & \multicolumn{1}{|c|}{ Date } & \multicolumn{1}{|c|}{$\$$} & \multicolumn{1}{|c|}{ Grantor } & \multicolumn{1}{|c|}{ Grantee } & \multicolumn{1}{|c|}{ Notes } & BCDR \\
\hline 16 & $2 / 2 / 1859$ & 376 & Beck, Joseph H. & Abat, Emil & 2 of 8 lots & R1:223 \\
\hline 16 & $7 / 25 / 1859$ & 480 & Abat, Emil & Maureaux, Paul & 2 of 8 lots & R1:476 \\
\hline 17 & $2 / 2 / 1859$ & 376 & Beck, Joseph H. & Abat, Emil & 3 of 8 lots & R1:223 \\
\hline 17 & $7 / 25 / 1859$ & 480 & Abat, Emil & Maureaux, Paul & 3 of 8 lots & R1:476 \\
\hline 18 & $2 / 2 / 1859$ & 376 & Beck, Joseph H. & Abat, Emil & 4 of 8 lots & R1:223 \\
\hline 18 & $7 / 25 / 1859$ & 480 & Abat, Emil & Maureaux, Paul & 4 of 8 lots & R1:476 \\
\hline 19 & $8 / 13 / 1855$ & 1725 & Beck, Joseph H. & Longworth, & 9 of 16 lots & N1:226 \\
\hline 19 & $6 / 26 / 1890$ & 4400 & Longworth, Nicholas (estate) & Dullnig, George & 1 of 4 lots & $64: 373$ \\
\hline 19 & $2 / 3 / 1892$ & 3000 & Dullnig, George & Zizelmann, Elimia & 1 of 2 lots & $95: 91$ \\
\hline
\end{tabular}

\section{Land North of Beckville}

The tract of land immediately north of Beckville was once owned by José de los Santos Hernandes alias Miralejos. Geraldo Hernandes eventually inherited the land from his father. The relatively small suerte was roughly bounded to the north by the Avenue of the Alameda (E. Commerce Street), to the west by Water Street and the Acequia Madre, and to the east by Third (Indianola) Street. A small irrigation ditch that defined the northern limits of Beckville also marked the southern limits of the Hernandes suerte (BCDR S1:355).

The suerte was subdivided into town lots 10 years after Beckville was subdivided. Geraldo Hernandes sold the undeveloped tract to Victor Considerant and Anthony Superville for $\$ 1,000$ in May 1858 . Victor Cousins, the city surveyor, subdivided the suerte for Considerant and Superville that same year. In January 1864, Augustus Morrisset purchased the rights and title from Superville (BCDR T1:152). That May, Angel C. Torres bought the land for $\$ 2,000$ (BCDR $\mathrm{T} 2: 337)$.

The lot became part of Block A (CB 687) and Block B (CB 686), as shown in Figure 9. Beckville's small irrigation ditch was already in place when the new lots were established. Hence, two large city blocks were constructed without the usual alley running through the center. CB 686 and CB 873 formed one large block, while CB 687 and CB 874 formed the other. Lafitte Street formed the contemporary northern boundary of both blocks.
According to Koch's drawing, all the lots on Block B (CB 686) had structures by 1873 . To the contrary, all the lots on Block A (CB 687) were vacant that same year (Figure 10). Block A was full by 1896 . Lots $1-4$ of CB 687 housed the Patrick Public School Number 5 (Figure 16), which later became known as the Burnet Public School.

\section{Summary}

Smythe's initial survey and Joseph Beck's subsequent real estate transactions suggest that although there may have been a few earlier structures, the vast majority of buildings in the project area were built between 1850 and 1875. Epidemics and the Civil War were just two factors which probably discouraged intensive settlement here until after 1865 . By the 1870 s, the project area was part of a well-established and relatively affluent community. With the exception of two lots on South Street, all the tracts in the project area were occupied by 1896 . Sanborn maps indicate that those two vacant tracts had structures in 1912 .

In some instances families remained for decades in the homes built by their ancestors. However, by the turn of the century many of the properties were already being occupied by tenants. Some of the more affluent families moved to larger homes. Small structures like the Amaya House became rental property. 
Construction of the arena, parking garage, and the lakes would have destroyed the foundations of historic dwellings, associated artifact scatters, and the upper sections of any other historic structures such as wells or privies. Surface inspection of other portions of the proposed project area indicate that the upper foot or so of sediment may have been removed by landscaping activities in parts of HemisFair Park. Conversely, in other areas landscaping activities have built up the surface and historic remains may be protected under berms. Construction and landscaping activities in each area will have different archaeological impact, and will influence the type and preservation of archaeological materials encountered on this project. While deeper intrusions may decrease the chance of finding in situ historic structures and artifacts, they may increase the possibility of revealing significant prehistoric occupations.

\section{Conclusions and Recommendations}

The archival research for the Convention Center demonstrates that from the establishment of the Mission San Antonio de Valero (the Alamo) until the mid-nineteenth century, the project area was primarily agricultural lands with no structures or improvements except the Alamo Acequia. In 1848 Joseph Beck purchased the land and subdivided it into residential lots. Over the next 12 years he sold the lots, and residential dwellings began to be constructed. Most of the owners were German, Polish, Anglo-American, and British. Documentary evidence such as Sanborn Insurance maps (1896, 1904, 1932 and 1952), Koch's 1873 Bird's Eye View of the City of San Antonio, and the photograph collection of the Institute of Texan Cultures show that a number of the original structures were extant, although not necessarily occupied, until their destruction for HemisFair Park in the 1960s. The alteration of the landscape was most severe during the initial subdivision of the project area into city blocks and construction of initial dwellings, and during the construction of HemisFair Park. The latter included removal of streets and property fences, planting of trees and grass, installation of sidewalks, and landmoving and leveling activities. It is unclear exactly where land-altering activities occurred and which lots were most affected.
During archaeological investigations in downtown San Antonio, numerous German and Anglo-American urban dwellings from the late 1800 s and early 1900 s were excavated (Bousman et al. 1995). These investigations documented numerous gaps in our archaeological knowledge of downtown San Antonio. These gaps can be defined in terms of nationality/ ethnicity affiliation, age, and preservation/integrity of archaeological remains.

In terms of nationality/ethnicity affiliation, prehistoric or early historic Native American, African-American, and Hispanic groups are still under-represented for any time period. However, for the late-nineteenth century, Germans and Anglo-American sites have received the most attention. Unless other factors come into play, investigation of German or Anglo-American dwellings would probably not be deemed worthy.

Historically significant time periods include Spanish colonial, Mexican Independence, Texas Revolution, Texas Independence, pre-Civil War, and Civil War. Other than the Spanish colonial period, very few historic sites pre-dating the 1870 s have been excavated and, in fact, very few investigations have provided well-defined archaeological components predating the 1890 s. Additionally, few prehistoric remains have been investigated in downtown San Antonio.

Few investigated early historic sites have good integrity and well-preserved contexts. In addition, most excavated historic dwellings were occupied for long periods of time, which is reflected by the recovered artifacts. Recent analysis of Alamodome artifacts indicate that artifact representation and frequencies are patterned by the context of the materials (Gross 1997), but it appears that no specific context is particularly under-represented in the available sample. All the available samples analyzed by Gross dated from the late-1800s to the mid-1900s. One limitation of these investigations is that no one single site has been fully investigated. If an undisturbed structure or dwelling representing a relatively brief time period could be located, it would offer the type of dating resolution, integrity, and context that would be worth investigating even if the occupants were German or Anglo-American. 
The archival research did not identify any significant archaeological resources that warrant intensive investigation in the immediate impact area. However, based on the history of this area, the above results, and previous archaeological investigations in downtown San Antonio, limited additional archaeological investigations are recommended. Three options are possible, each with specific pros and cons. In any case, the selected approach should be conducted with the full cooperation and approval of the Texas Historical Commission.

The first approach is to monitor all construction activities that will affect the lots in the Convention Center expansion impact area and any other areas that may be disturbed. Monitoring should be conducted by a qualified archaeologist, with the active participation of the Texas Historical Commission. If archaeological resources are discovered during the monitoring phase of investigations, it will be necessary to quickly assess their potential significance in consultation with the Texas Historical Commission, and cooperatively decide if further, more detailed, investigations are necessary. This may require a halt to construction activities. If no significant resources are discovered, then this will probably be the least expensive and most rapid option. However, if significant resources are uncovered, further investigations could result in construction delays.

A second option is to strip sediments with a backhoe or Gradall before construction begins, allowing archaeologists to monitor and control the effort. If significant resources are uncovered, then a plan can be implemented in consultation with the Texas Historical Commission to record the archaeological remains in an appropriate manner and without significant construction delays. This would probably result in slightly higher costs, but also in a shorter overall project schedule for the archaeological investigations and avoidance of construction delays.

A third approach is to fund a full-fledged testing project designed to conclusively identify all significant archaeological resources within the project area. If significant resources are uncovered, then a plan can be implemented in consultation with the Texas Historical Commission to record these archaeological remains in an appropriate manner and without significant construction delays. This option would take the most time and would probably be the most expensive, but would provide the most comprehensive and reliable results.

In any of the three cases, the assessment of significance and design of further archaeological investigations will require consultation with the Texas Historical Commission. It is impossible at this time to predict the location of potentially significant archaeological resources and, in fact, it is possible that none will be discovered. No significant archaeological resources are known to exist in the current impact area as shown on Figure 2. However, significant archaeological resources could be discovered. 


\section{References Cited}

Anderson, $\mathrm{M}$.

1964 The Federal Bulldozer, A Critical Analysis of Urban Renewal 1949-1962. Publications of the Joint Center for Urban Studies of the Massachusetts Institute of Technology and Harvard University. MIT Press, Cambridge.

Architectural Record

1968 High-rise Hotel Constructed Off-site. January, pp. 162-166

Banfield, E. C.

1968 The Unheavenly City: The Nature and Future of Our Urban Crisis. Little, Brown and Company, Boston.

Bilstein, R., and J. Miller

1985 Aviation in Texas. Texas Monthly, Austin.

Bolton, H. E.

1905 The Spanish Abandonment and Re-location of East Texas, 1773-1779. Quarterly of the Texas State Historical Association, IX(2):67-137.

1970[1915] Texas in the Middle Eighteenth Century: Studies in Spanish Colonial History and Administration. University of Texas Press, Austin.

Bousman, C. B., A. A. Fox, K. J. Gross, and I. W. Cox

1995 Historical Archaeology in Downtown San Antonio, Texas: An Evaluation of Properties at the Proposed VIA Downtown Park and Ride Facility. Archaeological Survey Report, No. 240. Center for Archaeological Research, The University of Texas at San Antonio.

Brewer, T.

1987 Mayor's Magic Wand, Blast Initiates HemisFair Project. San Antonio Express-News, 30 May.

Brown, K. M.

1996 La Villita Earthworks. In The New Handbook of Texas, edited by R. Tyler, 4:112-113. The Texas State Historical Association, Austin.

Business Week

1968a This World's Fair Has a Long Future. 30 March:66-71.

1968b HemisFair Licks Wounds. 21 September:40.

Campbell, T. N.

1975 The Payaya Indians of Southern Texas. Special Publications No. 1. Southern Texas Archaeological Association, San Antonio.

Campbell, T. N., and T. J. Campbell

1985 Indian Groups Associated with Spanish Missions of the San Antonio Missions National Historical Park. Special Report, No. 16. Center for Archaeological Research, The University of Texas at San Antonio.

Castañeda, C. E.

1936 Our Catholic Heritage in Texas 1519-1936. The Mission Era: The Winning of Texas 1693-1731, Volume II. Von Boeckmann-Jones, Austin.

Chabot, F. C.

1937 With the Makers of San Antonio. Artes Graficas, San Antonio. 
Chabot, F. C. (translator and editor)

1932 Excerpts from the Memorias for the History of the Province of Texas by Father Morfi. Naylor, San Antonio.

Chipman, D. E.

1992 Spanish Texas, 1519-1821. University of Texas Press, Austin.

1996 Olivares, Antonio de San Buenaventura y. In The New Handbook of Texas, edited by R. Tyler, 4:1145. The Texas State Historical Association, Austin.

Corning, $\mathrm{B}$.

1989 A Park That's Child's Play. San Antonio Express-News, 7 April.

1993 German Heritage Park Planned. San Antonio Express-News, 7 April.

Cox, I. W.

1992 Archaeological Monitoring for the Tri-Party Improvements Project, San Antonio, Bexar County, Texas. Archaeological Survey Report, No. 204. Center for Archaeological Research, The University of Texas at San Antonio.

Cox, I. W., and A. A. Fox

1983 Literature and Archival Study for the Development of HemisFair Park, San Antonio, Texas. Manuscript on file. Center for Archaeological Research, The University of Texas at San Antonio.

Crawford, S.

1988 Majordomo: Chronicle of an Acequia in Northern New Mexico. University of New Mexico Press, Albuquerque.

Current, R. N., T. H. Williams, F. Friedel, and A. Brinkley

1979 American History, Volume I: To 1877. Alfred A. Knopf, New York.

de la Teja, J. F.

1995 San Antonio de Bexxar: A Community on New Spain's Northern Frontier. University of New Mexico Press, Albuquerque.

1996 Seguín, Juan Nepomuceno. In The New Handbook of Texas, edited by R. Tyler, 5:966-967. The Texas State Historical Association, Austin.

de Paredes. M. S.

1727 Vista de las Misiones del Rio Grande del Norte pr Fr. Miguel Sevillano de Paredes en 15 de Octobre. Archivo General de Mexico: Historia, Volume 29. Barker History Center, The University of Texas at Austin.

Dobkins, B. E.

1959 The Spanish Element in Texas Water Law. University of Texas Press, Austin.

Doyle, J. K.

1996 Callaghan, Bryan V., Jr. In The New Handbook of Texas, edited by R. Tyler, 2:904. The Texas State Historical Association, Austin.

Duane, F.

1996 HemisFair '68. In The New Handbook of Texas, edited by R. Tyler, 3:548-549. The Texas State Historical Association, Austin.

Duffield, J.

1969 Year-old HemisFair Plaza Needs Quick Transfusion. San Antonio Express-News, 2 November. 
Ellsworth, C. E.

1923 The Floods In Central Texas In September, 1921. Water Supply Paper 488. Government Printing Office, Washington, D. C.

Encyclopedia Americana

1957 Volume 13. Americana, New York.

Enge, K. I., and S. Whiteford

1989 The Keepers of Water and Earth: Mexican Rural Social Organization and Irrigation. University of Texas Press, Austin.

Faulk, O. B.

1964 Last Years of Spanish Texas, 1778-1821. Morton and Company, London.

Fehrenbach, T. R.

1983 Lone Star, A History of Texas and the Texans. Macmillan, Toronto.

FitzSimon, L. J.

1996 Erskine, Andrew Nelson. In The New Handbook of Texas, edited by R. Tyler, 2:884-885. The Texas State Historical Association, Austin.

Fox, A. A.

1985 Testing for the Location of the Alamo Acequia (41BX8) at HemisFair Plaza, San Antonio, Texas. Archaeological Survey Report, No. 142. Center for Archaeological Research, The University of Texas at San Antonio.

Fox, A. A., and I. W. Cox

1990 Archaeological Excavations at the Alamo Acequia, Southwest Hemisfair Plaza, San Antonio, Bexar County, Texas. Archaeological Survey Report, No. 192. Center for Archaeological Research, The University of Texas at San Antonio.

Galbraith, J. K.

1972 The Great Crash, 1929. Houghton Mifflin, Boston.

Gross, K. J.

1997 Identification of Site Formation Processes at the Alamodome. In Archeology at the Alamodome: Investigations of a Neighborhood in Transition, Volume II: Excavations and Artifact Distribution Analysis, edited by A. A. Fox, M. Renner, and R. J. Hard. Archaeological Survey Report, No. 237. Center for Archeological Research, University of Texas at San Antonio. In press.

Guderjan, T. H., and C. S. Canty

1994 The Indian Texans. Institute of Texan Cultures, The University of Texas at San Antonio.

Gunn, J. W.

1996 Mexican Invasions of 1842. In The New Handbook of Texas, edited by R. Tyler, 4:686. The Texas State Historical Association, Austin.

Habig, M. A.

1968 The Alamo Chain of Missions: A History of San Antonio's Five Old Missions. Franciscan Herald, Chicago.

1977 The Alamo Mission: San Antonio de Valero 1718-1793. Franciscan Herald, Chicago.

Hagner, L. M.

1947 Alluring San Antonio: Through the Eyes of an Artist. Clemens, San Antonio. 
Henderson, R. B.

1970 Maury Maverick, A Political Biography. University of Texas Press, Austin.

Hoffmann, F. L. (translator)

1935 Diary of the Alarcón Expedition into Texas, 1718-1719. Quivira Society Publications, Volume 5. Arno, New York.

1938 The Mesquía Diary of the Alarcón Expedition into Texas, 1718. Southwestern Historical Quarterly XII:312-323.

House, B.

1968[1949] San Antonio: City of Flaming Adventure. Hemisfair '68 edition. Naylor, San Antonio.

Jackson, J.

1986 Los Mesteños: Spanish Ranching in Texas, 1721-1821. Texas A\&M University Press, College Station.

Johnson, E. D., and I. W. Cox

1995 An Archival and Archaeological Study for the Relocation of Three Historic Homes in Hemisfair Park, San Antonio, Texas. Archaeological Survey Report, No. 241. Center for Archaeological Research, The University of Texas at San Antonio.

Johnson, J. G.

1996 Arciniega, José de. In The New Handbook of Texas, edited by R. Tyler, 1:234-235. The Texas State Historical Association, Austin.

Labadie, J. H. (assembler)

1986 La Villita Earthworks (41BX677): San Antonio, Texas. A Preliminary Report of Investigations of Mexican Siege Works at the Battle of the Alamo. Archaeological Survey Report, No. 159. Center for Archaeological Research, The University of Texas at San Antonio.

La Fora, J. F.

1958 The Frontier of New Spain: Nicolas de la Fora's Description, 1766-68, translated by L. Kinnaird. The Quivira Society, Berkeley.

Leatherwood, A.

1996 Texas Folklife Festival. In The New Handbook of Texas, edited by R. Tyler, 6:334. The Texas State Historical Association, Austin.

Martinez, G.

1987 City Spends $\$ 53$ Million But Yet Stalled Project. San Antonio Express-News, 23 August.

Montgomery, R.

1968 HemisFair '68: Prologue to Renewal. Architectural Forum 129:4-89.

Moore, R. V.

1996 Bastrop, Baron de. In The New Handbook of Texas, edited by R. Tyler, 1:410. The Texas State Historical Association, Austin.

Newcomb, W. W., Jr.

1993 The Indians of Texas: From Prehistoric to Modern Times. University of Texas Press, Austin.

Newsweek

1968 Fair Enough. 30 September:76

Nixon, P. I.

1936 A Century of Medicine in San Antonio. Privately published, San Antonio. 
Padilla, J. A.

1919 Texas in 1820. Translated by M. A. Hatcher. Southwestern Historical Quarterly 23:47-68.

Pesquera, A.

1993a A Magnet For Dreams. San Antonio Express-News. 28 March:10a.

1993b Plans Come, Go in 25 Years. San Antonio Express-News. 28 March.

Phillips, S.

1987 \$25 Million Revitalization Plan for HemisFair Plaza. San Antonio Express-News, 4 April.

Poyo, G. E., and G. M. Hinojosa (editors)

1991 Tejano Origins in Eighteenth-Century San Antonio. University of Texas Press, Austin.

Ramsdell, C.

1985 San Antonio: A Historical and Pictorial Guide. Second edition. University of Texas Press, Austin.

Roell, C.H.

1996 Dimmitt, Philip. In The New Handbook of Texas, edited by R. Tyler, 4:648-650. The Texas State Historical Association, Austin.

Rybczyk, M. L.

1992 San Antonio Uncovered. Wordware, Plano, Texas.

San Antonio Express-News (SAEN)

1886 [article concerning snowfall]. 13 January.

1917 President Asks Congress to Declare State of War Exists. 2 April.

1917 San Antonio to Have 60,000 Troops. 15 June.

1917 Another Aviation Field Near City for Government. 30 August.

1917 Brooks Field to be Name of New Aviation Ground. 11 December.

1921 Caught Unaware, Sleeping Scores are Suddenly Swept Off. 11 September.

1926 Finishing Touches Put to Huge Dam. 28 August.

1929 Plans To Beautify 'Big Bend' Meets Mayor's Approval. 27 June.

1929 History Repeats on Wall Street. 26 October.

1930 Great Bend Work Accepted. 18 March.

1939 River Beautification Project to Start at Ceremony Friday. 19 March.

1940 Lights and Music. 29 April.

1941 50,000 See Fiesta Open Despite Rain. 22 April.

1942 A New Parade Loop is Being Formed. 24 April.

1965 Plea for 22 Historic Sites Filed. 10 December.

1967 HemisFair Bill Signed by Governor. 16 February.

1868 [sale and auction announcement]. 4 July.

1968 S.A.'s HemisFair Becomes Reality. 6 April.

1968 Was HemisFair Worth It? 6 October.

1968 Fair Site Transition Under Way. 8 October.

1988 Hemisfair Redevelopment Plan Out. 18 March.

1988 HemisFair Plaza is now HemisFair Park. 10 June.

1993 Hemisfair: 25th Anniversary. 28 March.

Scanlan, C. C.

1996 Smith, John William. In The New Handbook of Texas, edited by R. Tyler, 5:1104-1105. The Texas State Historical Association, Austin.

Schuetz, M. K.

1970 Excavation of a Section of the Acequia Madre in Bexar County, Texas, and Archeological Investigations at Mission San Jose in April 1968. Archeological Report 19. Texas Historical Survey Committee, Austin. 
Slayman, E. J.

1968b Court Orders Fair Facilities Held. San Antonio Express-News. 8 October.

Tolson, $\mathrm{M}$.

1993 HemisFair Sparked San Antonio 'Reawakening.' San Antonio Light. 4 January.

Wall, R. P. (editor)

1968 Hemisfair 1968 Official Souvenir Guidebook. A. H. Belo, Dallas.

Webb, W. P. (editor)

1952 The Handbook of Texas. Two volumes. The Texas State Historical Association, Austin.

Weber, D. J.

1992 The Spanish Frontier in North America. Yale University Press, New Haven.

Weddle, R. S.

1968 San Juan Bautista, Gateway to Spanish Texas. University of Texas Press, Austin.

1996 La Salle Expedition. In The New Handbook of Texas, edited by R. Tyler, 4:86-87. The Texas State Historical Association, Austin.

Whitson, L. J.

1996 University of Texas at San Antonio. In The New Handbook of Texas, edited by R. Tyler, 6:659. The Texas State Historical Association, Austin.

Zunker, V. G.

1983 A Dream Come True: Robert Hugman and the San Antonio Riverwalk. Privately published, San Antonio. 


\section{Appendix A}

\section{Photographs, HemisFair Park}

The following properties are located in HemisFair Park but not within this project's construction area. These are standing and demolished structures that were present when HemisFair Park was built. The photographs are organized by street address. These photographs represent a sample of the nineteenth-century architecture in the park. Each structure has been named, either by the most promient owner or by its known name. When additional information is available it is listed below the name. The photo numbers in the caption correspond to the structure numbers on the map in Figure A-25 (at the end of the appendix).

\section{South Alamo Street}

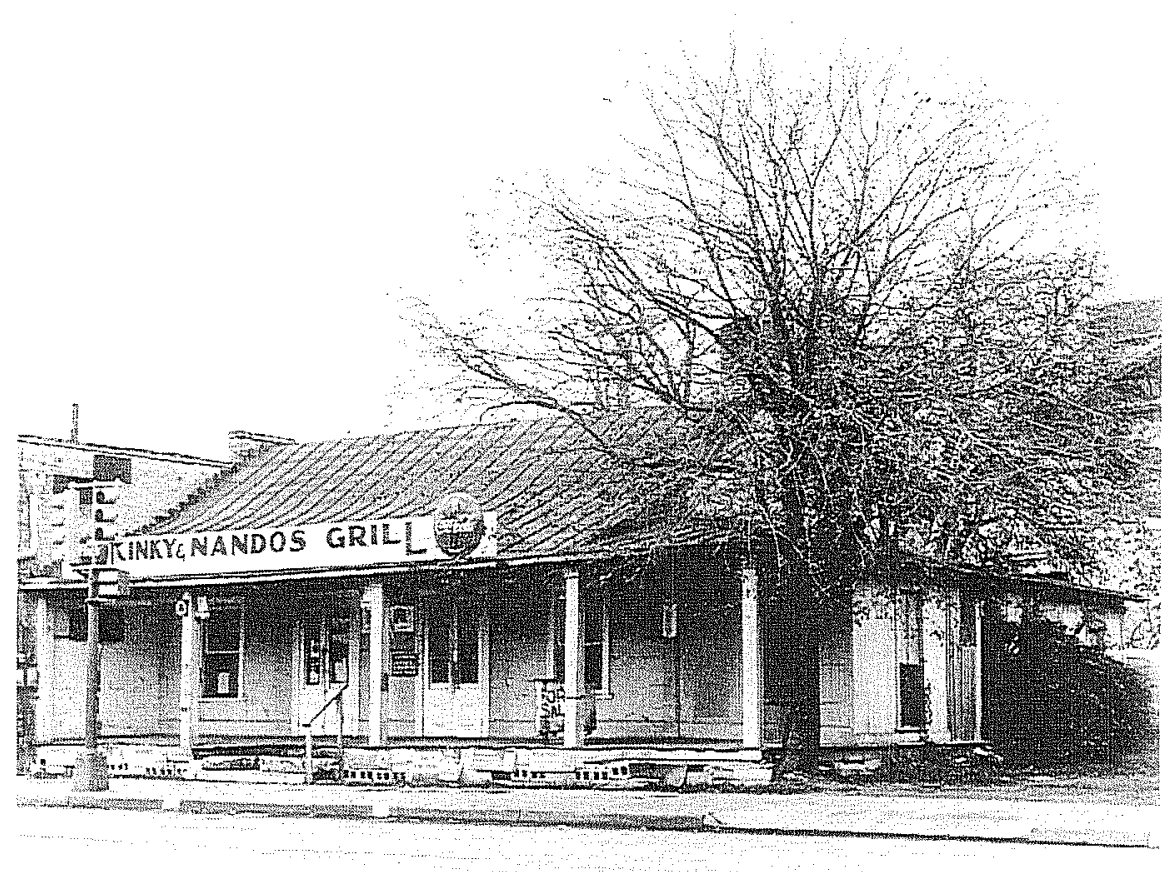

Figure A-1. Photo 1: Kinky and Nandos Grill. 404 South Alamo Street. Demolished. (ITC Photo 82-575, ca. 1966).

Kinky and Nando Flores ran their business from this structure in 1950. They were the last owners when the building was demolished for the widening of South Alamo Street, just prior to HemisFair. The two brothers also had a tire company next door at 402 South Alamo Street. 


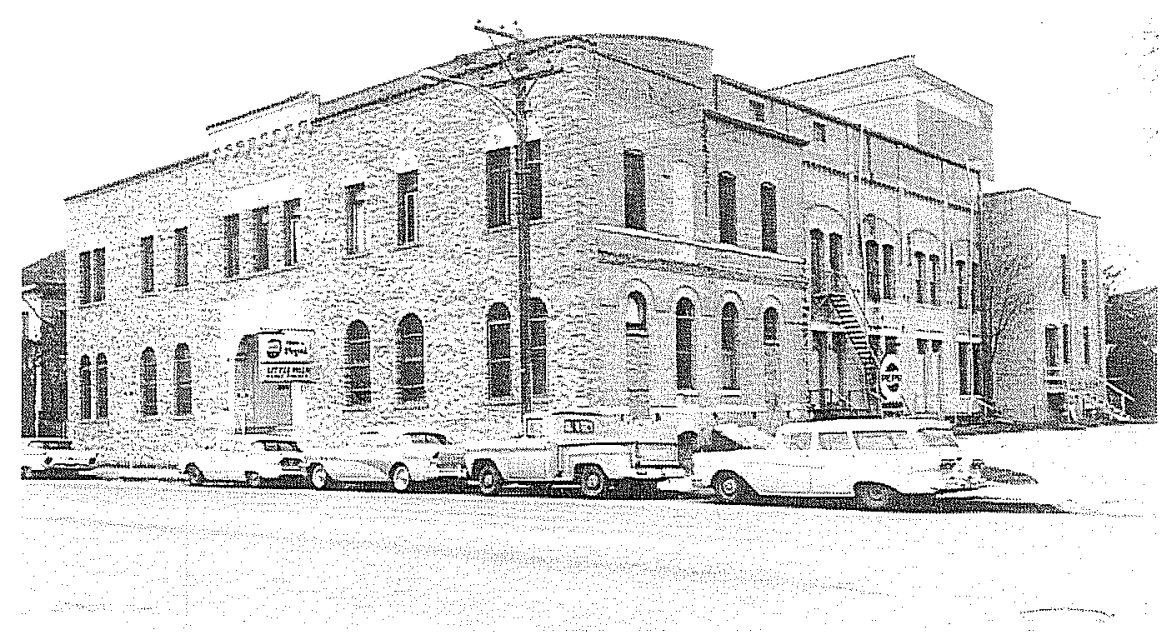

Figure A-2. Photo 2: Beethoven Hall. 418 South Alamo Street. Existing structure. (ITC Photo 82-574, ca. 1966).

Beethoven Hall was built in 1895 by the German Mannerchor, a singing society founded in 1867 . The structure that stands today is missing its original facade, dome, columns, and symbolic harp. These were removed to widen South Alamo Street. 
Figure A-3. Photo 3: Eager House. 434 South Alamo Street. Existing structure (ITC Photo 82599, ca. 1966)
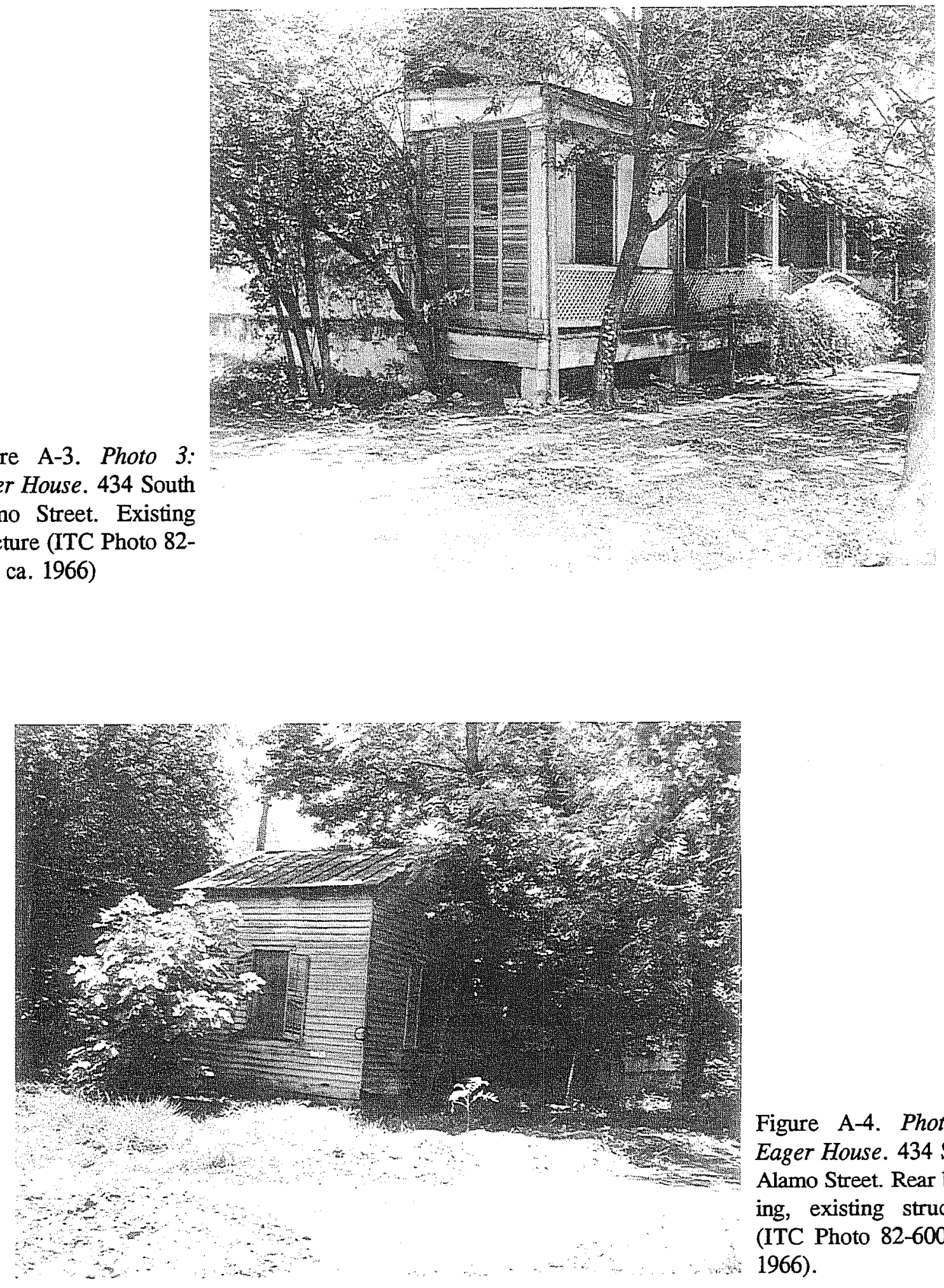

Figure A-4. Photo 4. Eager House. 434 South Alamo Street. Rear building, existing structure. (ITC Photo 82-600, ca. 1966).

Built in 1866, this house was a wedding present from John Riddle to his daughter Sarah, who married Robert Eager that same year. The Eager family owned and lived on the property up until the urban renewal project. Remodeled for use at HemisFair, today the name on the door reads "Casa Tamaulipas." 


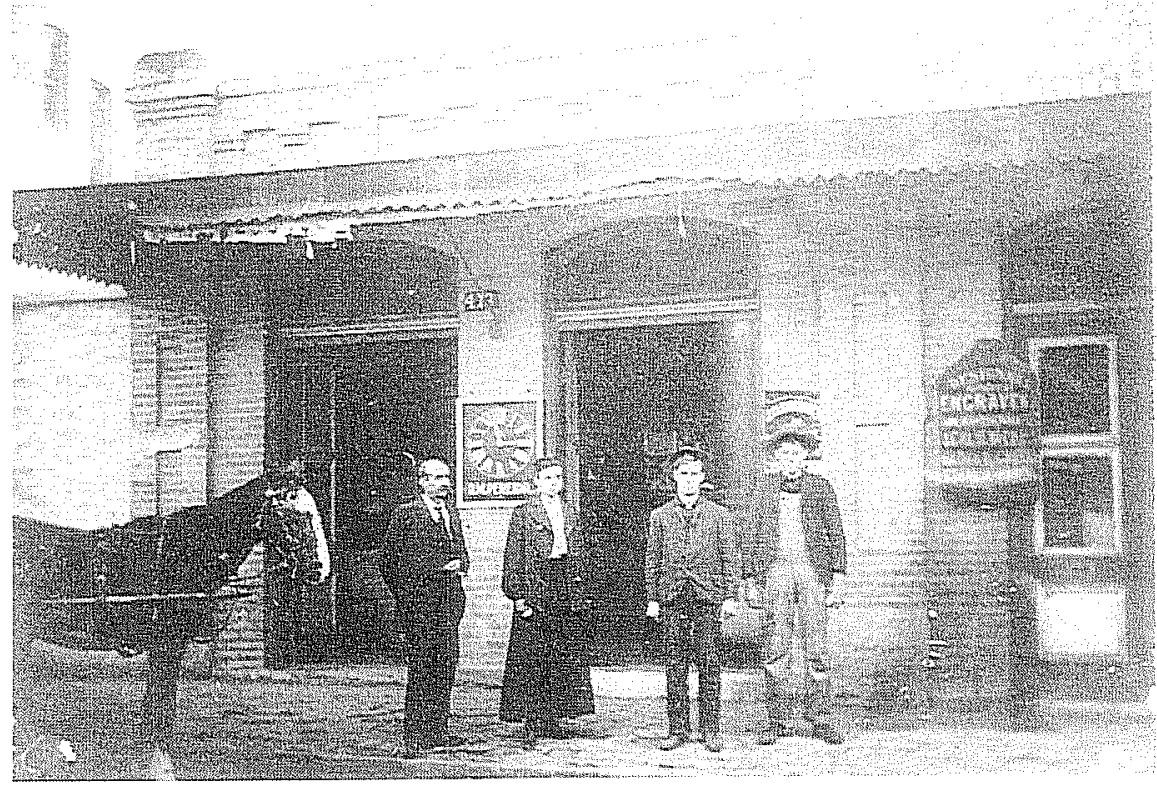

Figure A-5. Pereida family in front of their business on Navarro Street. (ITC Photo 9014 , ca. 1890s).

Figure A-6. Photo 5: Pereida House. 502 South Alamo Street. Existing structure. Note the snow, which according to the $S A E N$ (13 January 1886) "metamorphosed the general appearance of our quaint old tropical city." (ITC Photo 90-15, 1886).

This house sits on part of the property that was a wedding gift from John Riddle to his daughter Sarah. R. M. Pereida later purchased the lot and built this house in 1883. The Pereidas were descended from one of the Canary Island familes, and Pereida Street is named for them. Mr. Pereida owned a jewelry store and was choir director at San Fernando Cathedral. The Pereida House is now known as Casa Jaliscio. 


\section{Goliad Street}

Figure A-7. Photo 6: Garza House. 121 Goliad Street. Demolished. (ITC Photo 82-595, ca. 1966)

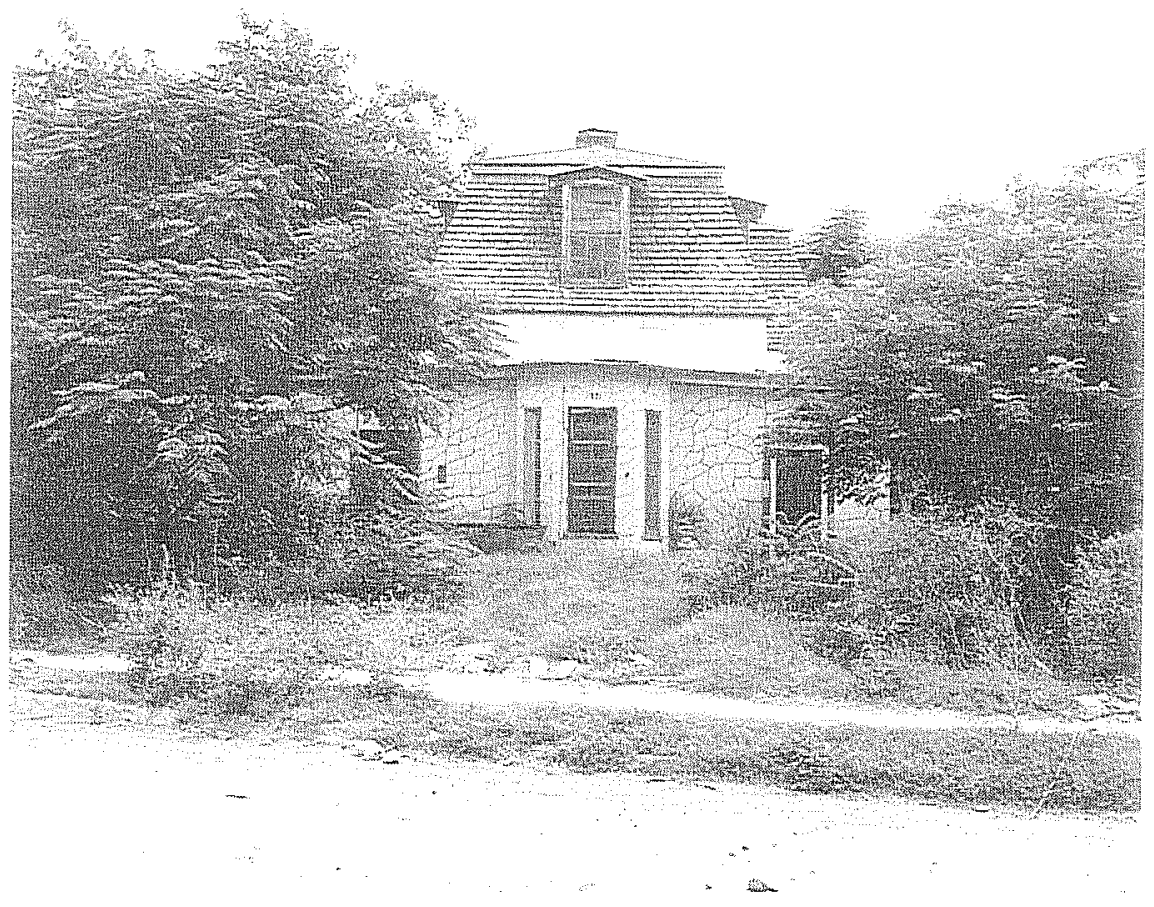

This two-story structure with wrought-iron work was designed and built by Herman Schultze, Sr., in 1891.

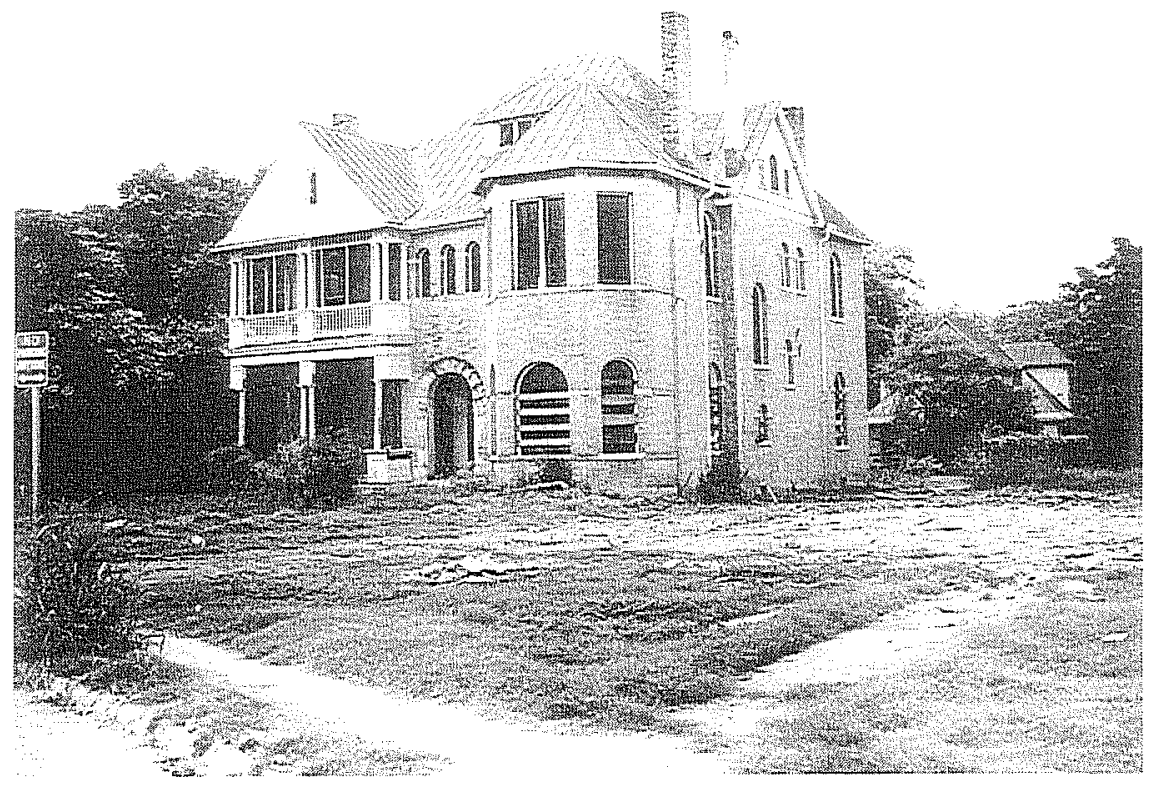

Figure A-8. Photo 7: Longini-Herrmann House. 138 Goliad Street. Existing structure. (ITC Photo 82-596, ca. 1966) 
Figure A-9. Photo 8:

M. Halff House. 139

Goliad Street. Existing Structure (ITC Photo 82594, ca. 1966).

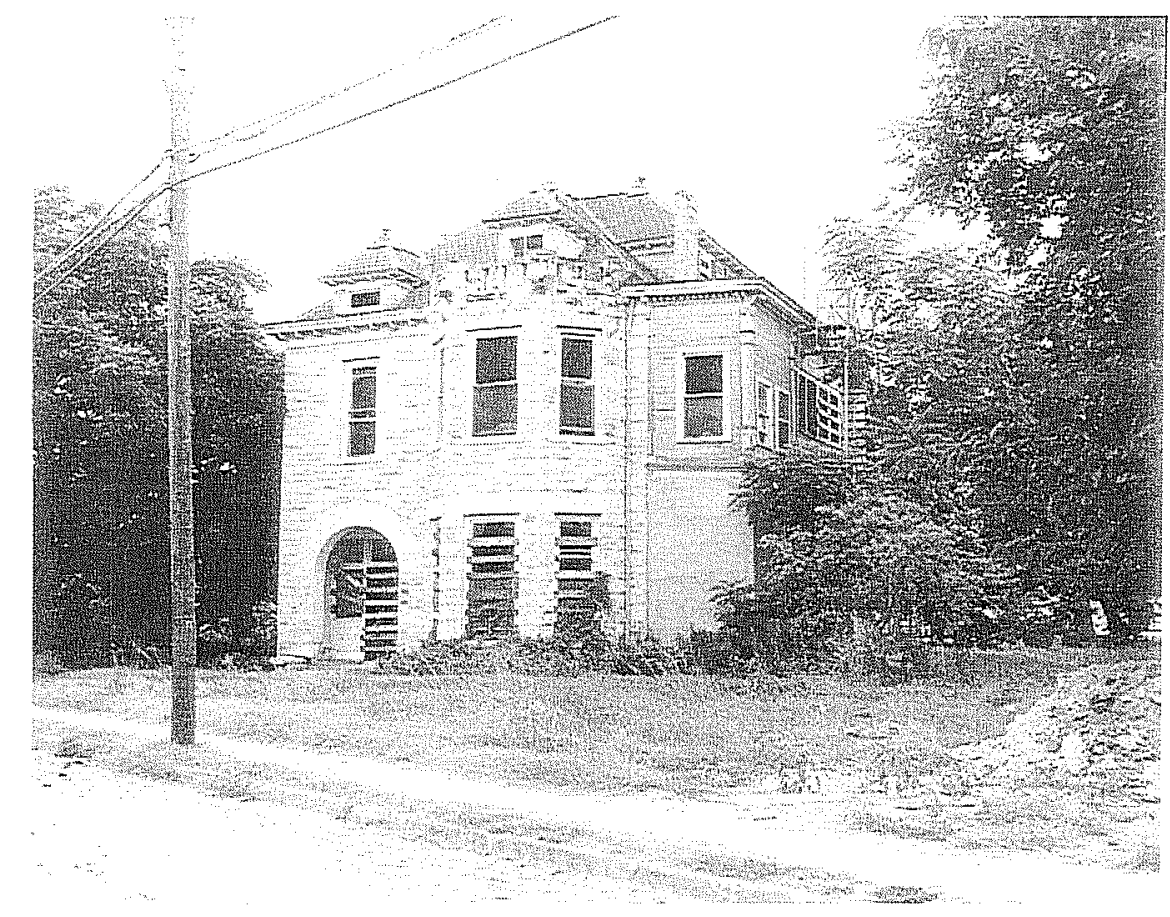

Alfred Giles designed this two-and-one-half-story Victorian limestone home. The structure was later remodeled for use at HemisFair.

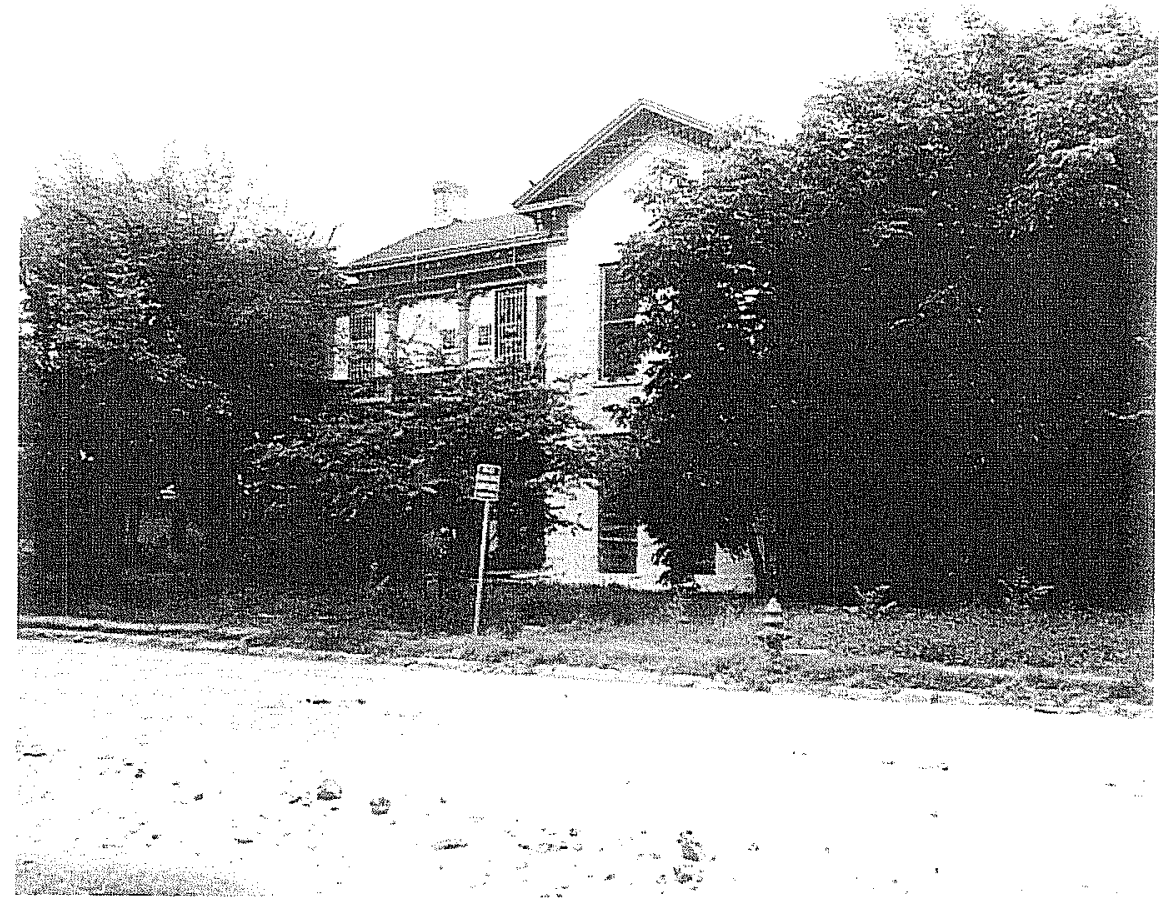

Figure A-10. Photo 9:

S. Halff House. 142 Goliad Street. Existing structure. (ITC Photo 82597, ca. 1966). 


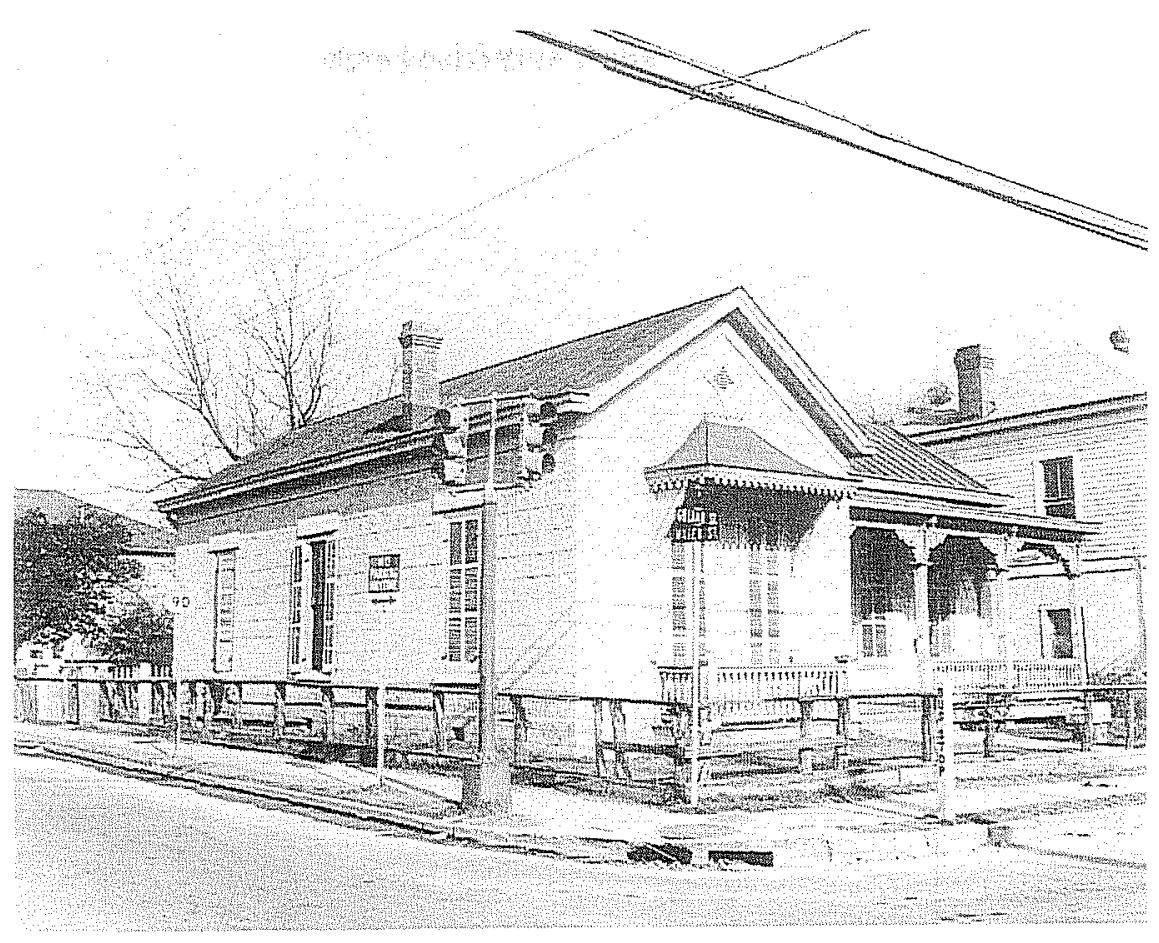

Figure A-11. Photo 10: Kusch House. 301 Goliad Street. Existing structure. (ITC Photo 82-571, ca. 1966).

An early transaction shows that Joseph Beck sold Lots 1 and 2 for $\$ 275$ in July 1856 to "Rice and Childrens [sic]" (BCDR 01:296). The lot was still unimproved in 1873 but the one-story Victorian limestone house is shown on 1896 Sanborn maps. The Kusch family called 301 Goliad Street home for more than 80 years. Built by John Kusch in 1885 , it was continuously occupied by a member of the Kusch family up until HemisFair (CD). As with many of the remodeled structures, the Kusch House served as a restaurant during the fair. HemisFair visitors knew it as the Fonda Santa Anita Restaurant (Wall 1968:113). Today it still sits on the corner of Goliad and Water streets. 


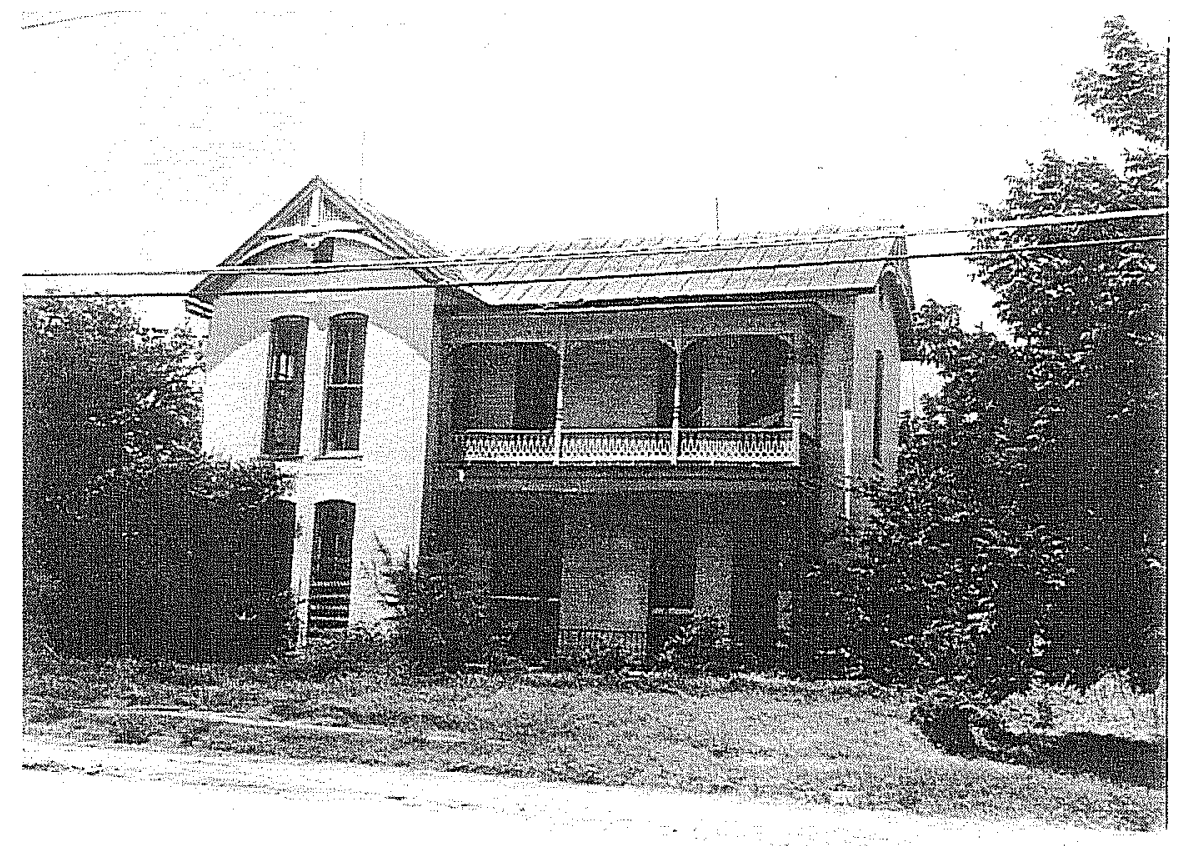

Figure A-12. Photo 11:

315 Goliad Street.

Demolished. (ITC Photo

82-602, ca. 1966).

Figure A-13. Photo 12: 315 Goliad Street. Rear view. Demolished. (ITC Photo 82-603, ca. 1966).

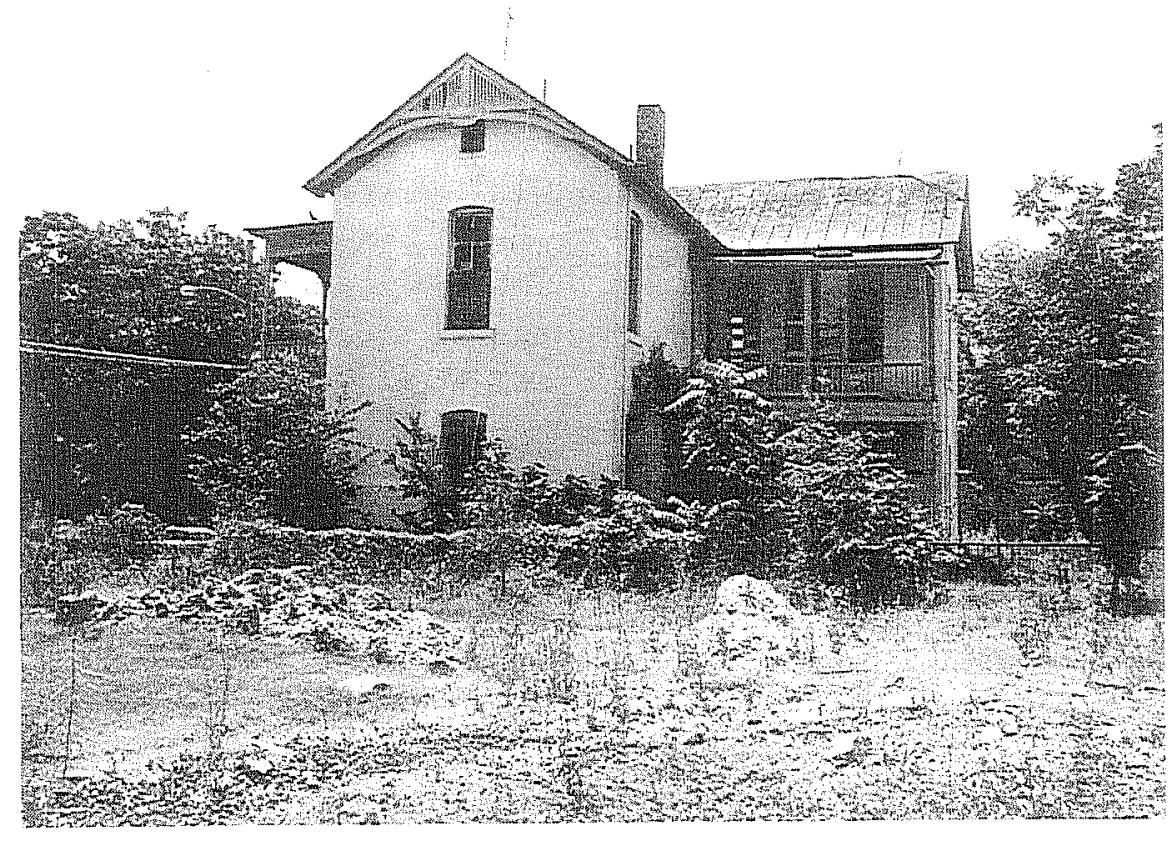




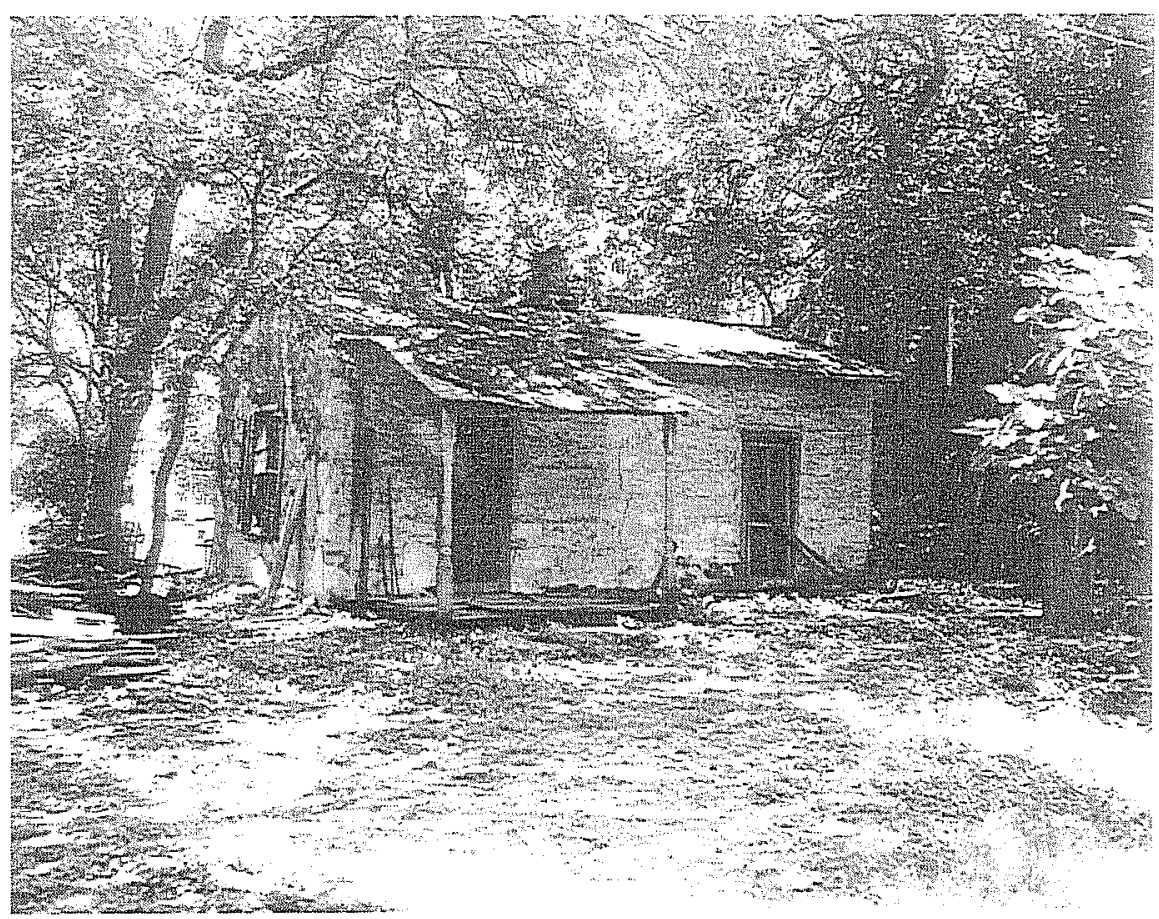

Figure A-14. Photo 13: 315 Goliad Street. Rear building, demolished. (ITC Photo 82-601, ca. 1966). 


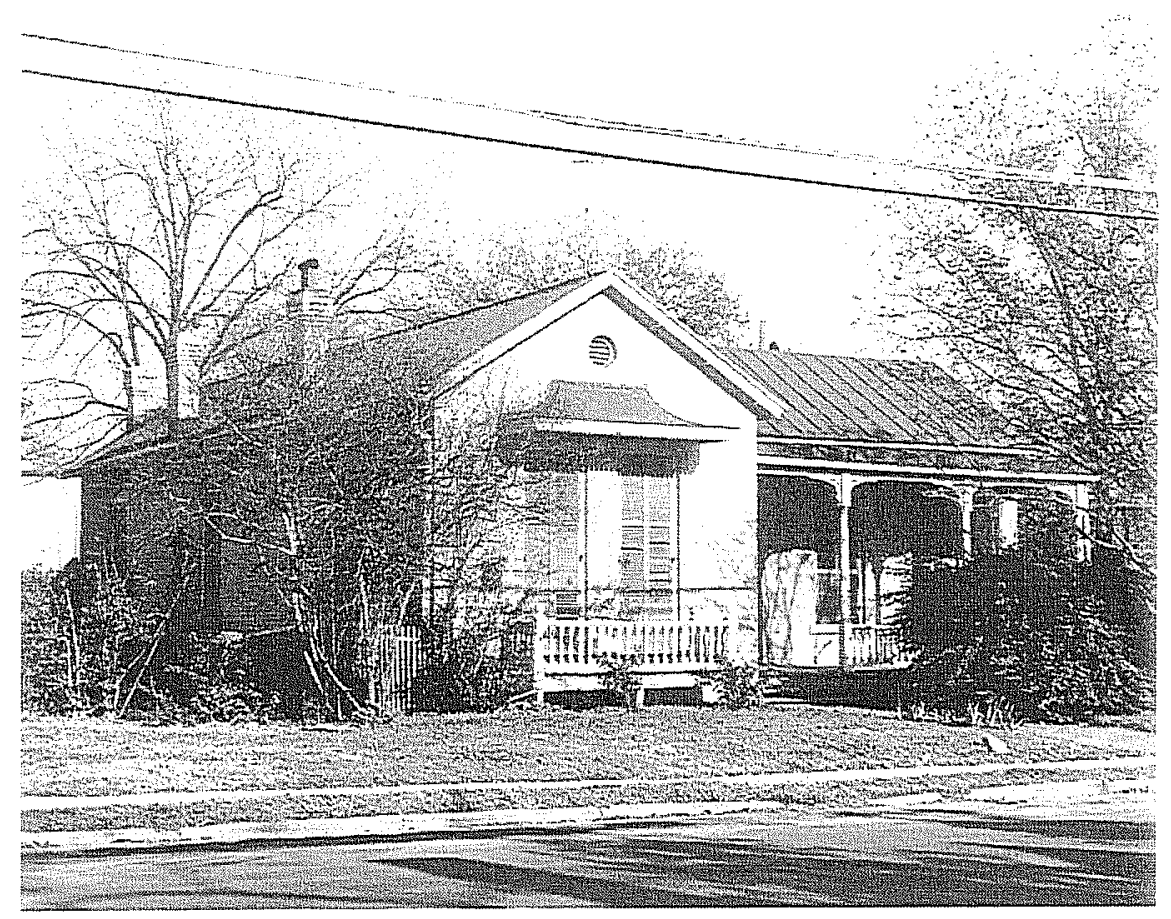

Figure A-15. Photo 14: Max Schultze House. 331 Goliad Street. Existing structure. (ITC Photo 82-570, ca. 1966).

This lot was one of 16 purchased from Joseph Beck by Nicholas Longworth for $\$ 1,725$ in August 1855 (BCDR, N1:226). Koch's 1873 drawing shows that the lot was still vacant in 1873 . George Dullnig bought the tract from the Longworth estate in May 1890 and sold it to Mrs. Emma Schultze in August 1893 (BCDR 72:128, 128:212). The Victorian home was probably built around this time as it is in place on the 1896 Sanborn Map. The house and property remained with the Schultze family until it was obtained by the city as part of the urban renewal project for HemisFair (CD). Walter M. Schultze was the last owner, he lived here during the house's final years with the family. The home was restored, and during HemisFair it served as the Sur le Pouce, a Swiss bakery/restaurant (Wall 1968:116). 


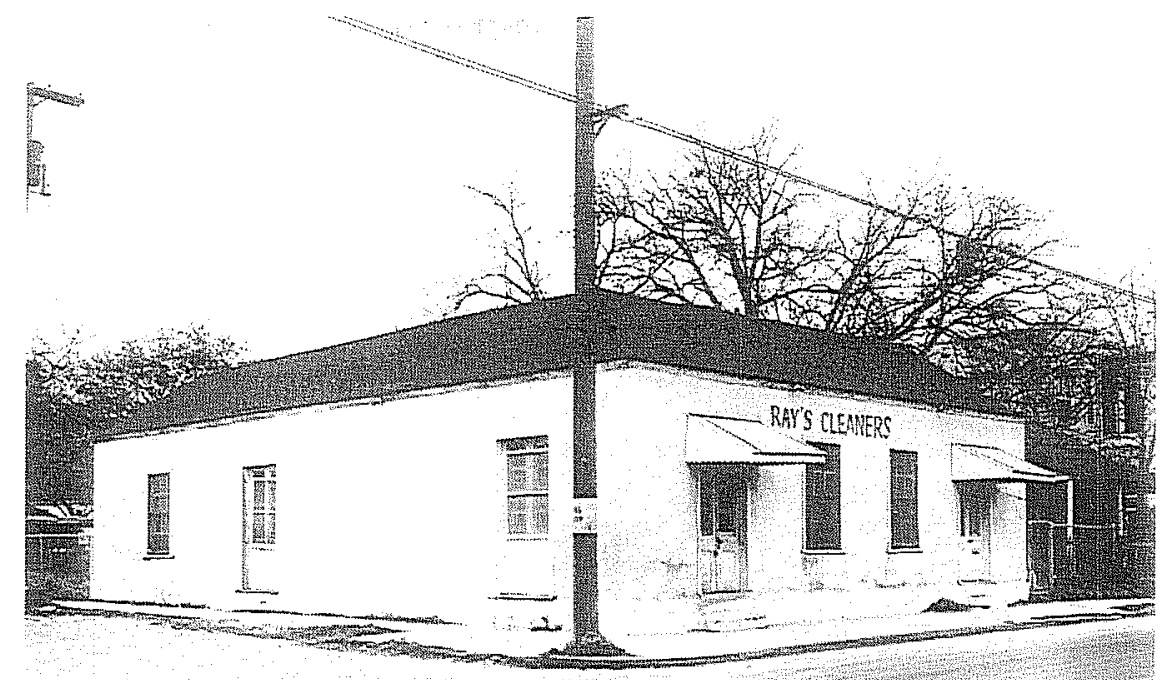

Figure A-16. Photo 15:

401 Goliad Street. Existing structure. (ITC Photo 82-576 ca. 1966, ca. 1966).

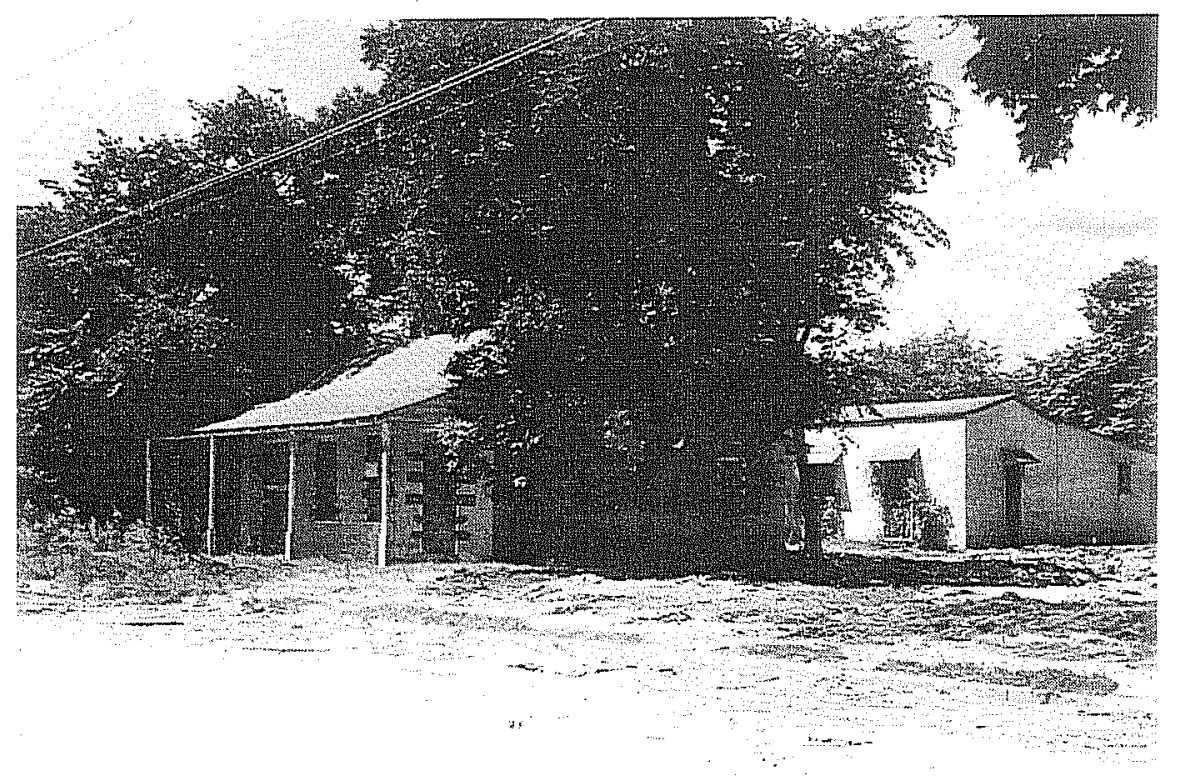

Figure A-17. Photo 16: 405 Goliad Street. Existing structure. (ITC Photo 82-604, ca. 1966). 


\section{Matagorda Street}

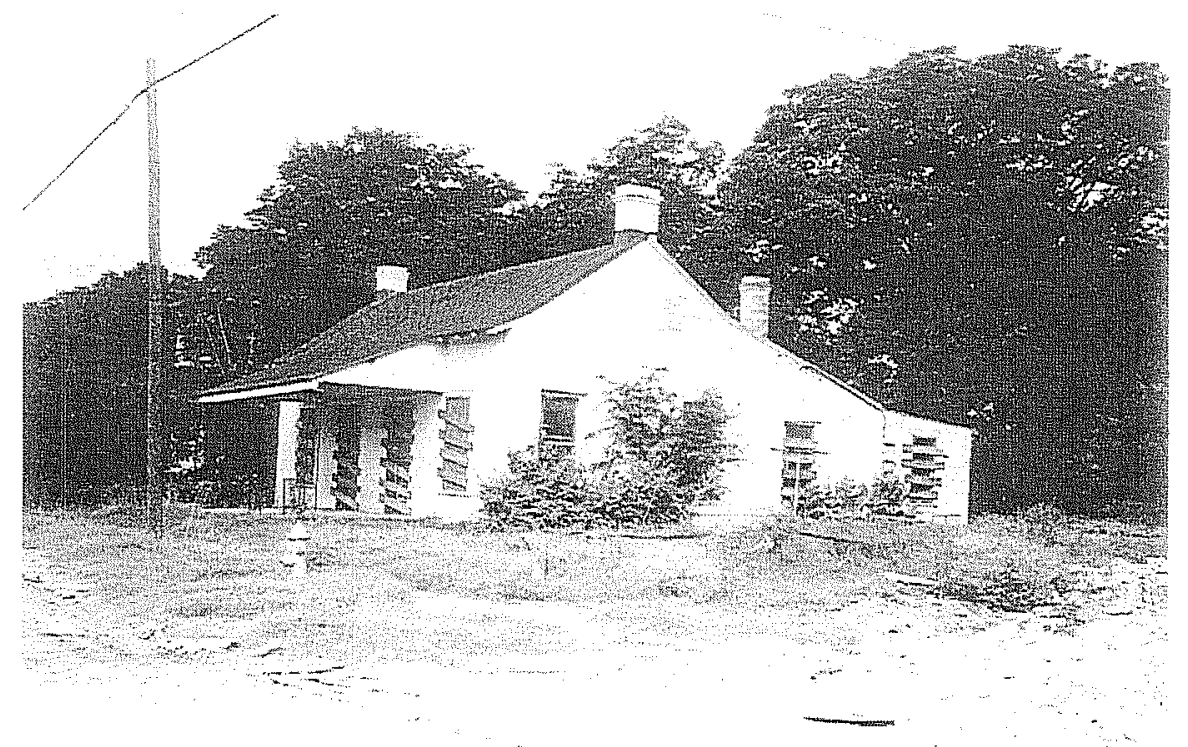

Figure A-18. Photo 17: 401 Matagorda Street. Demolished. (ITC Photo 82-584, ca. 1966).

Figure A-19. Photo 18: 414 Matagorda Street. Ruins. (ITC Photo 82 583, ca. 1966).

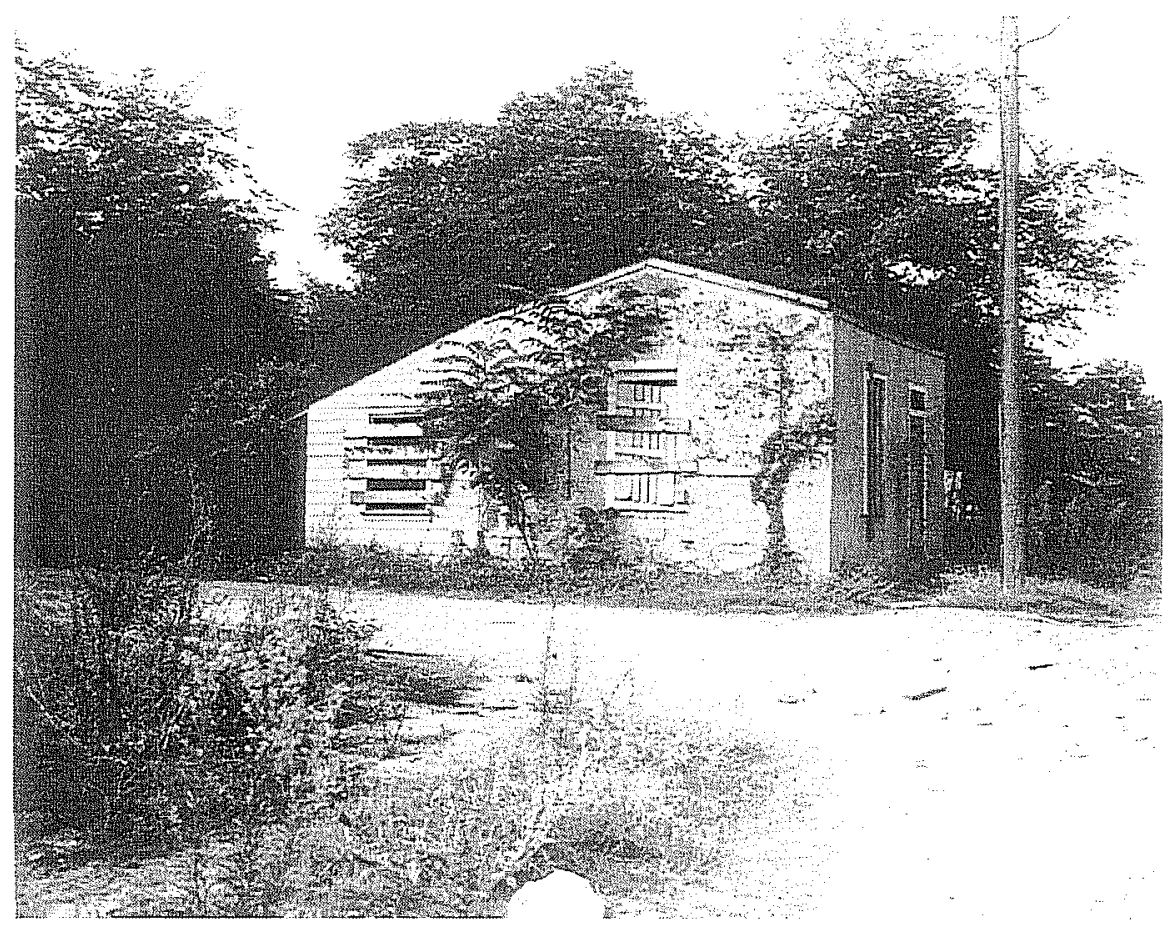




\section{North Street}

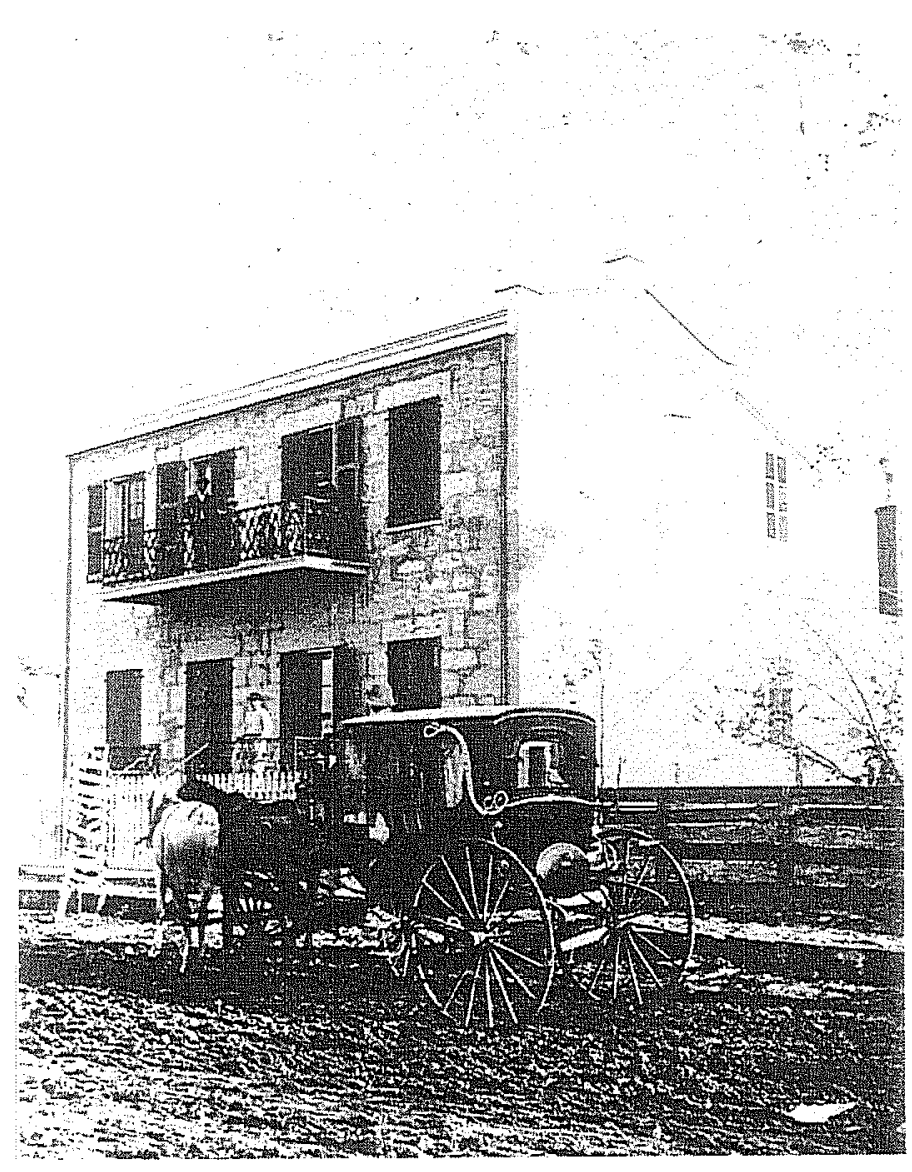

Figure A-20. Photo 19: 144 North Street. Demolished. (ITC Photo 1228-C, ca. 1870s).

The first two-story building to be erected in the community was located at 144 North Street. Originally owned by F. I. Meyer, the material for the house was transported from New Orleans to San Antonio by oxcart teams. Construction of the house was completed in 1870 (Hagner 1947:35). Franc Meyer is listed on this block in the city's first published directory of 1877 . The Meyer family lived here throughout the house's nearly 100 -year history (CDs). Mrs. Mary Meyer was still there in 1960 when the block was nearly vacant. The building was finally listed as vacant in 1965 . 


\section{South Street}

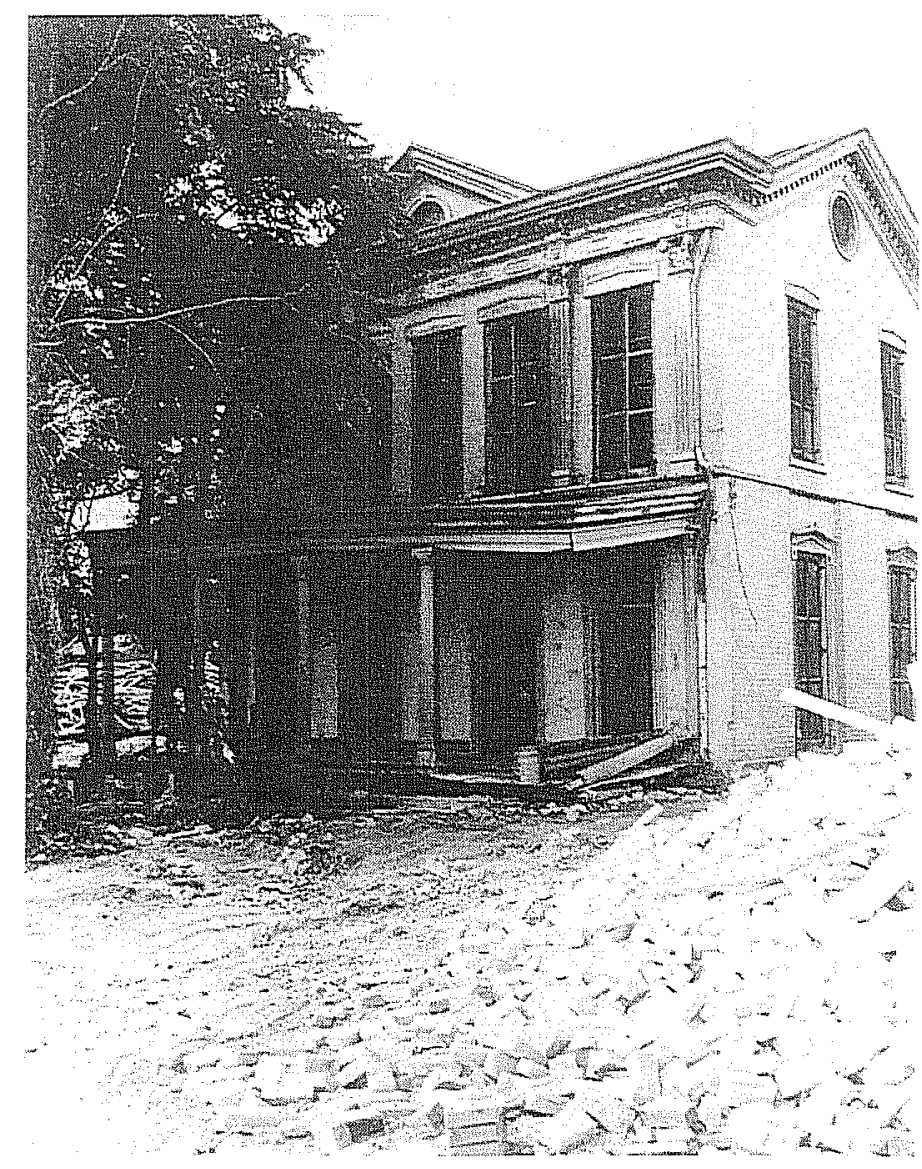

Figure A-21. Photo 20: Original Schultze House. 114 South Street. Demolished. (ITC Photo 82-587, ca. 1966)

A replica of this house was built on Goliad Street for use at HemisFair. This original structure was demolished to make room for a parking lot near the Convention Center. 


\section{Water Street}

Figure A-22. Photo 21: Smith House. 503 Water Street. Existing structure. (ITC Photo 82-572, ca. 1966).

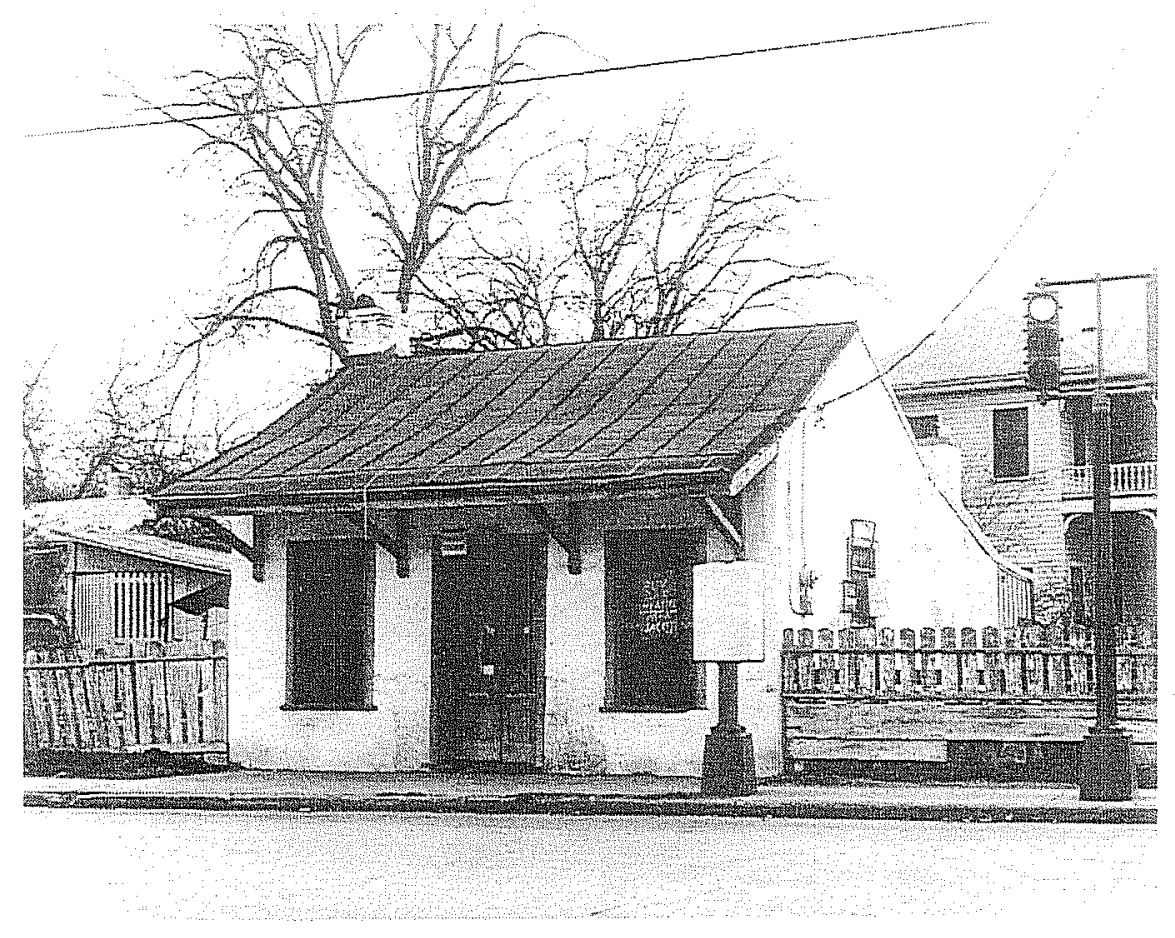

Currently the location of Klassic Krafts.

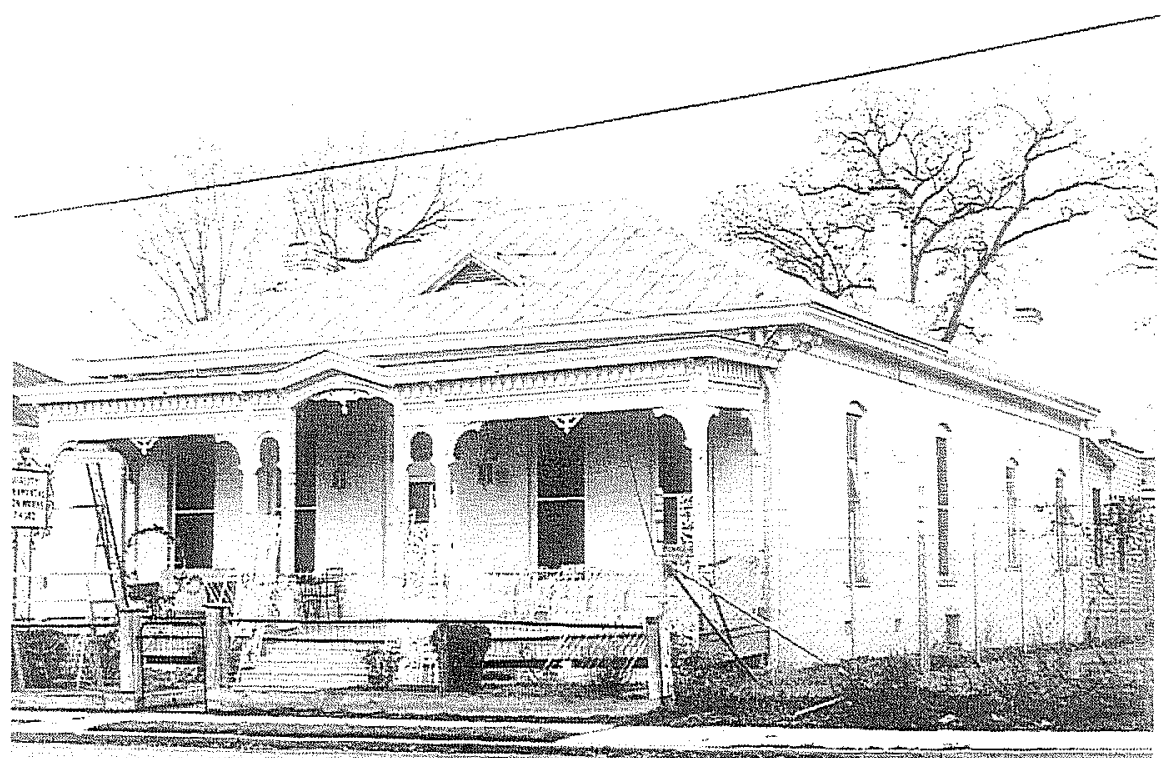

Figure A-23. Photo 22: Quality Ornamental Iron Works. 617 Water Street. Demolished. (ITC Photo $82-605$, ca. 1966) 


\section{Wyoming Street}

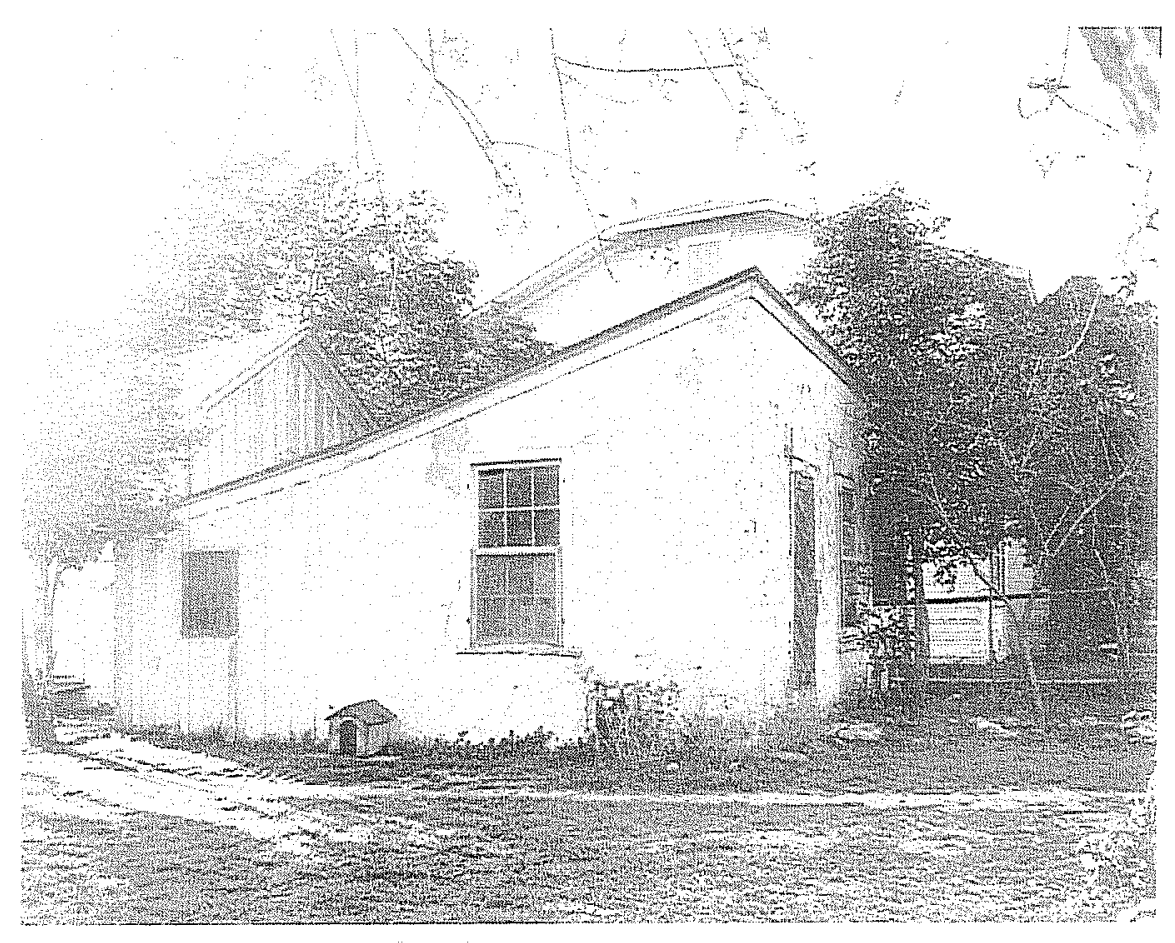

Figure A-24. Photo 23: Duelm House. 232/234 Wyoming Street. Demolished. (ITC Photo 82-569, ca. 1966)

This small limestone building with a shed roof was later remodeled for use at HemisFair. Duelm family members who resided here included Annie in 1950 and Charles in 1890 (CD). The lot was first sold by Joseph Beck to Isaac J. Lyons in February 1859 and the house is shown on the tract (see Figure 9) in 1873 (BCDR R1:248). 


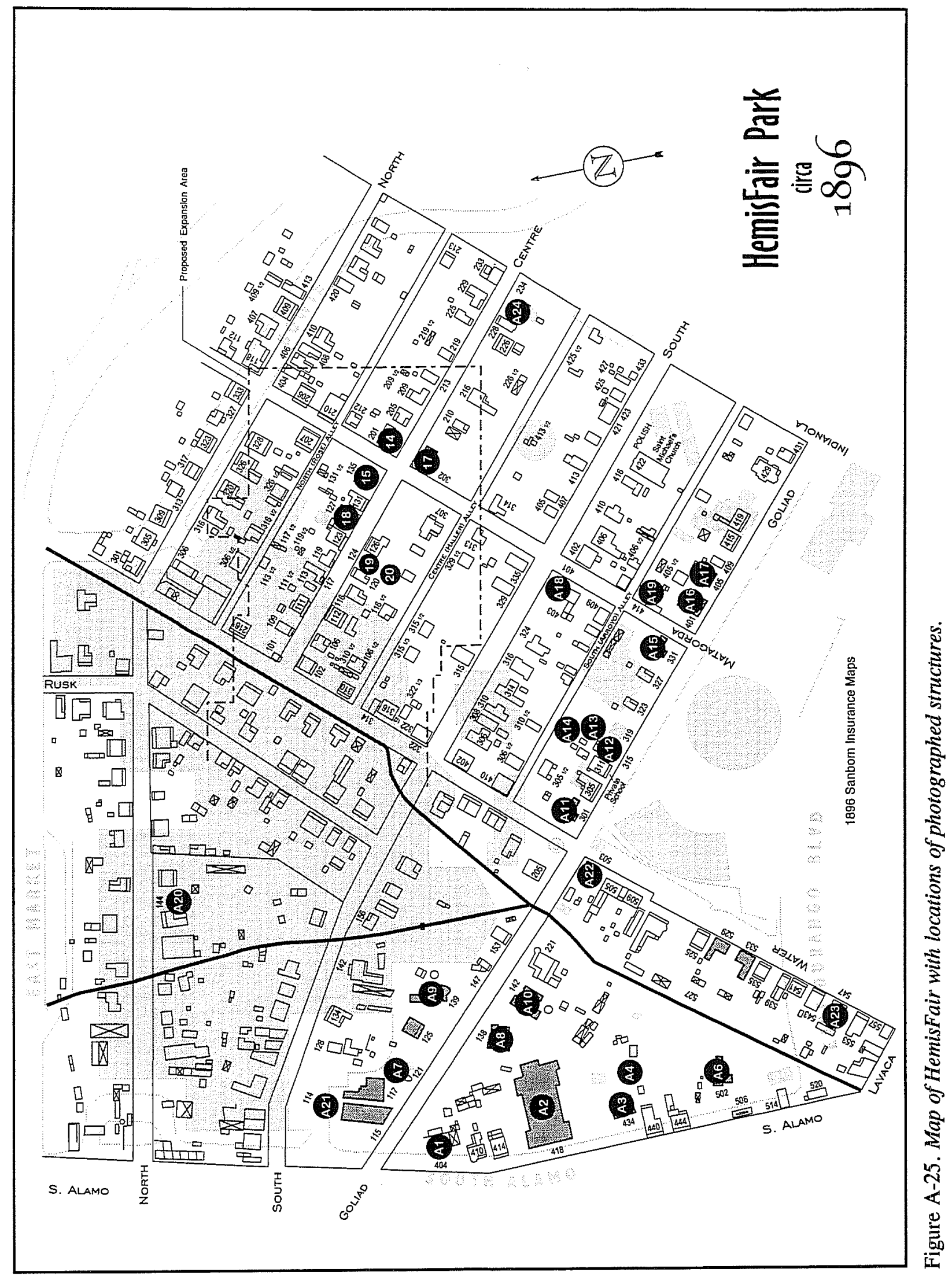




\section{Appendix B}

\section{Early Beckville Deed Transactions}

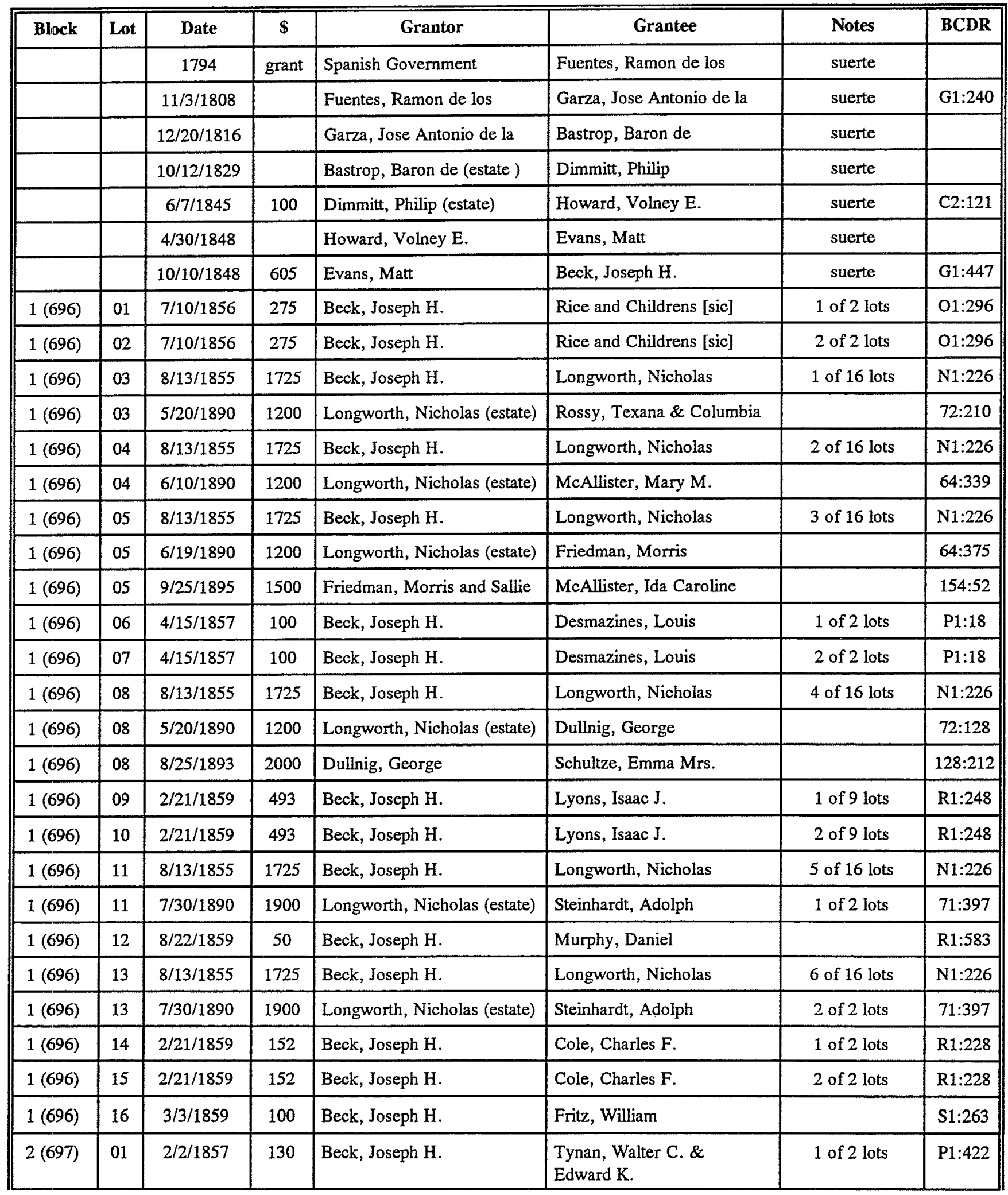




\begin{tabular}{|c|c|c|c|c|c|c|c|}
\hline Block & Lot & Date & $\$$ & Grantor & Grantee & Notes & BCDR \\
\hline $2(697)$ & 01 & $12 / 31 / 1859$ & 250 & Tynan, W. C. \& Edward K. & Rzeppa, Emanuel & lof 2 lots & $\mathrm{R} 1: 636$ \\
\hline $2(697)$ & 01 & $7 / 18 / 1868$ & 2200 & Rzeppa, Emanuel & Richter, Carl August & 1 of 2 lots & U1:495 \\
\hline $2(697)$ & 02 & $2 / 2 / 1857$ & 130 & Beck, Joseph H. & Tynan, W. C. \& Edward K. & 2 of 2 lots & $\mathrm{P} 1: 422$ \\
\hline $2(697)$ & 02 & $12 / 31 / 1859$ & 250 & Tynan, W. C. \& Edward K. & Rzeppa, Emanuel & 2 of 2 lots & $\mathrm{R} 1: 636$ \\
\hline $2(697)$ & 02 & $5 / 16 / 1867$ & 1500 & Rzeppa, Emanuel & Dugosh, Albert \& Barbara & & $\mathrm{U} 2: 154$ \\
\hline $2(697)$ & 02 & $7 / 18 / 1868$ & 2200 & Rzeppa, Emanuel & Richter, Carl August & 2 of 2 lots & U1:495 \\
\hline $2(697)$ & 03 & $1 / 6 / 1857$ & 100 & Beck, Joseph H. & Zyzik, Zydor & & O2:311 \\
\hline $2(697)$ & 04 & $5 / 29 / 1857$ & 210 & Beck, Joseph H. & Kingsbury, William & 1 of 3 lots & $\mathrm{P} 2: 14$ \\
\hline $2(697)$ & 05 & $11 / 1856$ & 250 & Beck, Joseph H. & Post, Garret P. & 1 of 5 lots & $02: 236$ \\
\hline $2(697)$ & 06 & $11 / 1856$ & 250 & Beck, Joseph H. & Post, Garret P. & 2 of 5 lots & O2:236 \\
\hline $2(697)$ & 06 & $12 / 2 / 1897$ & 750 & Aniol, Jacob (estate) & Taylor, D. S. & & $160: 558$ \\
\hline $2(697)$ & 07 & $1 / 7 / 1858$ & 265 & Beck, Joseph H. & Taylor, P. C. & 1 of 5 lots & $\mathrm{P} 2: 378$ \\
\hline $2(697)$ & 08 & $11 / 1856$ & 250 & Beck, Joseph H. & Post, Garret P. & 3 of 5 lots & $02: 236$ \\
\hline $2(697)$ & 09 & $3 / 14 / 1855$ & 150 & Beck, Joseph H. & McMonigle, Connell & 1 of 2 lots & G2:135 \\
\hline $2(697)$ & 10 & $3 / 14 / 1855$ & 150 & Beck, Joseph H. & McMonigle, Connell & 2 of 2 lots & G2:135 \\
\hline $2(697)$ & 11 & $11 / 1856$ & 250 & Beck, Joseph H. & Post, Garret P. & 4 of 5 lots & O2:236 \\
\hline $2(697)$ & 12 & $11 / 1856$ & 250 & Beck, Joseph H. & Post, Garret P. & 5 of 5 lots & $02: 236$ \\
\hline $2(697)$ & 13 & $2 / 21 / 1859$ & 216 & Beck, Joseph H. & French, John C. & 1 of 4 lots & $\mathrm{H} 2: 6$ \\
\hline $2(697)$ & 14 & $2 / 21 / 1859$ & 216 & Beck, Joseph H. & French, John C. & 2 of 4 lots & $\mathrm{H} 2: 6$ \\
\hline $2(697)$ & 15 & $2 / 21 / 1859$ & 216 & Beck, Joseph H. & French, John C. & 3 of 4 lots & $\mathrm{H} 2: 6$ \\
\hline $2(697)$ & 16 & $2 / 21 / 1859$ & 216 & Beck, Joseph H. & French, John C. & 4 of 4 lots & $\mathrm{H} 2: 6$ \\
\hline $2(697)$ & 17 & $5 / 29 / 1857$ & 210 & Beck, Joseph H. & Kingsbury, William & 2 of 3 lots & $\mathrm{P} 2: 14$ \\
\hline $2(697)$ & 18 & $5 / 29 / 1857$ & 210 & Beck, Joseph H. & Kingsbury, William & 3 of 3 lots & $\mathrm{P} 2: 14$ \\
\hline $2(697)$ & 19 & $6 / 12 / 1860$ & 132 & Beck, Joseph $\mathrm{H}$. & Newcomb, James P. & 1 of 2 lots & $\mathrm{S} 1: 295$ \\
\hline $2(697)$ & 20 & $6 / 12 / 1860$ & 132 & Beck, Joseph H. & Newcomb, James P. & 2 of 2 lots & S1:295 \\
\hline $3(693)$ & 01 & $8 / 13 / 1855$ & 1725 & Beck, Joseph H. & Longworth, Nicholas & 7 of 16 lots & $\mathrm{N} 1: 226$ \\
\hline $3(693)$ & 01 & $5 / 23 / 1890$ & 1200 & Longworth, Nicholas (estate) & Seffel, Josephine & & $76: 372$ \\
\hline $3(693)$ & 02 & $2 / 21 / 1859$ & 493 & Beck, Joseph H. & Lyons, Isaac J. & 3 of 9 lots & $\mathrm{R} 1: 248$ \\
\hline $3(693)$ & 03 & $8 / 13 / 1855$ & 1725 & Beck, Joseph H. & Longworth, Nicholas & 8 of 16 lots & $\mathrm{N} 1: 226$ \\
\hline $3(693)$ & 03 & $7 / 18 / 1890$ & 2700 & Longworth, Nicholas (estate) & Steinhardt, Adolph & 1 of 3 lots & $72: 484$ \\
\hline $3(693)$ & 04 & $2 / 21 / 1859$ & 150 & Beck, Joseph H. & Florian, E. A. & 1 of 3 lots & $\mathrm{R} 1: 166$ \\
\hline $3(693)$ & 05 & $2 / 21 / 1859$ & 150 & Beck, Joseph H. & Florian, E. A. & 2 of 3 lots & $\mathrm{R} 1: 166$ \\
\hline $3(693)$ & 06 & $2 / 21 / 1859$ & 150 & Beck, Joseph H. & Florian, E. A. & 3 of 3 lots & $\mathrm{R} 1: 166$ \\
\hline $3(693)$ & 07 & $2 / 21 / 1859$ & 493 & Beck, Joseph H. & Lyons, Isaac J. & 4 of 9 lots & $\mathrm{R} 1: 248$ \\
\hline $3(693)$ & 08 & $2 / 21 / 1859$ & 493 & Beck, Joseph H. & Lyons, Isaac J. & 5 of 9 lots & $\mathrm{R} 1: 248$ \\
\hline $3(693)$ & 09 & $2 / 21 / 1859$ & 93 & Beck, Joseph H. & Eamardhisrs, Willis & 1 of 2 lots & $\mathrm{H} 2: 72$ \\
\hline
\end{tabular}




\begin{tabular}{|c|c|c|c|c|c|c|c|}
\hline Block & Lot & Date & $\$$ & Grantor & Grantee & Notes & BCDR \\
\hline $3(693)$ & 10 & $2 / 21 / 1859$ & 93 & Beck, Joseph H. & Eamardhisrs, Willis & 2 of 2 lots & $\mathrm{H} 2: 72$ \\
\hline $3(693)$ & 11 & $1 / 23 / 1854$ & 82.50 & Beck, Joseph H. & Brackett. A. B. & fractional block & L2:211 \\
\hline $3(693)$ & 11 & $3 / 14 / 1855$ & 198 & Beck, Joseph H. & Smith, Sam S. & 1 of 3 lots & M2:639 \\
\hline $3(693)$ & 11 & $1 / 3 / 1863$ & 750 & Smith, Sam S. & Wurzbach, Francis & 1 of 3 lots & S2:504 \\
\hline $3(693)$ & 12 & $1 / 23 / 1854$ & 61 & Beck, Joseph H. & Brackett. A. B. & fractional block & L2:212 \\
\hline $3(693)$ & 12 & $3 / 14 / 1855$ & 198 & Beck, Joseph H. & Smith, Sam S. & 2 of 3 lots & M2:639 \\
\hline $3(693)$ & 12 & $1 / 3 / 1863$ & 750 & Smith, Sam S. & Wurzbach, Francis & 2 of 3 lots & S2:504 \\
\hline $3(693)$ & 13 & $2 / 21 / 1859$ & 493 & Beck, Joseph H. & Lyons, Isaac J. & 6 of 9 lots & $\mathrm{R} 1: 248$ \\
\hline $3(693)$ & 14 & $2 / 21 / 1859$ & 493 & Beck, Joseph H. & Lyons, Isaac J. & 7 of 9 lots & $\mathrm{R} 1: 248$ \\
\hline $3(693)$ & 15 & $2 / 2 / 1859$ & 376 & Beck, Joseph H. & Abat, Emil & 1 of 8 lots & $\mathrm{R} 1: 223$ \\
\hline $3(693)$ & 15 & $7 / 25 / 1859$ & 480 & Abat, Emil & Maureaux, Paul & 1 of 8 lots & $\mathrm{R} 1: 476$ \\
\hline $3(693)$ & 16 & $2 / 2 / 1859$ & 376 & Beck, Joseph H. & Abat, Emil & 2 of 8 lots & $\mathrm{R} 1: 223$ \\
\hline $3(693)$ & 16 & $7 / 25 / 1859$ & 480 & Abat, Emil & Maureaux, Paul & 2 of 8 lots & $\mathrm{R} 1: 476$ \\
\hline $3(693)$ & 17 & $2 / 2 / 1859$ & 376 & Beck, Joseph H. & Abat, Emil & 3 of 8 lots & $\mathrm{R} 1: 223$ \\
\hline $3(693)$ & 17 & $7 / 25 / 1859$ & 480 & Abat, Emil & Maureaux, Paul & 3 of 8 lots & $\mathrm{R} 1: 476$ \\
\hline $3(693)$ & 18 & $2 / 2 / 1859$ & 376 & Beck, Joseph H. & Abat, Emil & 4 of 8 lots & $\mathrm{R} 1: 223$ \\
\hline $3(693)$ & 18 & $7 / 25 / 1859$ & 480 & Abat, Emil & Maureaux, Paul & 4 of 8 lots & $\mathrm{R} 1: 476$ \\
\hline $3(693)$ & 19 & $8 / 13 / 1855$ & 1725 & Beck, Joseph H. & Longworth, N. & 9 of 16 lots & $\mathrm{N} 1: 226$ \\
\hline $3(693)$ & 19 & $6 / 26 / 1890$ & 4400 & Longworth, Nicholas (estate) & Dullnig, George & 1 of 4 lots & $64: 373$ \\
\hline $3(693)$ & 19 & $2 / 3 / 1892$ & 3000 & Dullnig, George & Zizelmann, Elimia & 1 of 2 lots & 95:91 \\
\hline $3(693)$ & 20 & $8 / 13 / 1855$ & 1725 & Beck, Joseph H. & Longworth, $\mathrm{N}$. & 10 of 16 lots & $\mathrm{N} 1: 226$ \\
\hline $3(693)$ & 20 & $6 / 26 / 1890$ & 4400 & Longworth, Nicholas (estate) & Dullnig, George & 2 of 4 lots & $64: 373$ \\
\hline $3(693)$ & 20 & $2 / 8 / 1892$ & 3000 & Dullnig, George & Zizelmann, Elimia & 2 of 2 lots & 95:91 \\
\hline $4(692)$ & 01 & $12 / 26 / 1856$ & 220 & Beck, Joseph H. & Schrier, Anton & 1 of 2 lots & P1:276 \\
\hline $4(692)$ & 01 & $1 / 18 / 1858$ & 110 & Schrier, Anton & Weikzonack, Frantz & 1 of 2 lots $s$ half & $\mathrm{P} 2: 520$ \\
\hline $4(692)$ & 01 & $9 / 2 / 1863$ & 250 & Wyglendalz, Anton & Weikzonack, Barbara & 1 of 4 lots n $1 / 2$ & $\mathrm{~T} 1: 26$ \\
\hline $4(692)$ & 02 & $12 / 26 / 1856$ & 220 & Beck, Joseph H. & Schrier, Anton & 2 of 2 lots & P1:276 \\
\hline $4(692)$ & 02 & $1 / 18 / 1858$ & 110 & Schrier, Anton & Weikzonack, Frantz & 2 of 2 lots $s$ half & $\mathrm{P} 2: 520$ \\
\hline $4(692)$ & 02 & 9/2/1863 & 250 & Wyglendalz, Anton & Weikzonack, Barbara & 2 of 4 lots $n$ half & $\mathrm{T} 1: 26$ \\
\hline $4(692)$ & 03 & $3 / 8 / 1859$ & 75 & Beck, Joseph H. & Wyglendalz, Anton & 1 of 2 lots & $\mathrm{H} 2: 75$ \\
\hline $4(692)$ & 03 & $9 / 2 / 1863$ & 250 & Wyglendalz, Anton & Weikzonack, Barbara & 3 of 4 lots $n$ half & $\mathrm{T} 1: 26$ \\
\hline $4(692)$ & 04 & $3 / 8 / 1859$ & 75 & Beck, Joseph H. & Wyglendalz, Anton & 2 of 2 lots & $\mathrm{H} 2: 75$ \\
\hline $4(692)$ & 04 & $9 / 2 / 1863$ & 250 & Wyglendalz, Anton & Weikzonack, Barbara & 4 of 4 lots $n$ half & $\mathrm{T} 1: 26$ \\
\hline $4(692)$ & 05 & $8 / 13 / 1855$ & 1725 & Beck, Joseph H. & Longworth, Nicholas & 11 of 16 lots & $\mathrm{N} 1: 226$ \\
\hline $4(692)$ & 05 & $7 / 18 / 1890$ & 2700 & Longworth, Nicholas (estate) & Steinhardt, Adolph & 2 of 3 lots & $72: 484$ \\
\hline $4(692)$ & 06 & $8 / 13 / 1855$ & 1725 & Beck, Joseph H. & Longworth, N. & 12 of 16 lots & $\mathrm{N} 1: 226$ \\
\hline
\end{tabular}




\begin{tabular}{|c|c|c|c|c|c|c|c|}
\hline Block & Lot & Date & $\$$ & Grantor & Grantee & Notes & BCDR \\
\hline $4(692)$ & 06 & $7 / 18 / 1890$ & 2700 & Longworth, Nicholas (estate) & Steinhardt, Adolph & 3 of 3 lots & $72: 484$ \\
\hline $4(692)$ & 07 & $12 / 22 / 1859$ & 160 & Beck, Joseph H. & Moodie, John & 1 of 2 lots & $\mathrm{S} 1: 140$ \\
\hline $4(692)$ & 07 & $9 / 10 / 1860$ & 115 & Moodie, John & Randziora, Vincent & & $\mathrm{S} 1: 416$ \\
\hline $4(692)$ & 08 & $12 / 22 / 1859$ & 160 & Beck, Joseph H. & Moodie, John & 2 of 2 lots & $\mathrm{S} 1: 140$ \\
\hline $4(692)$ & 08 & $11 / 12 / 1860$ & 125 & Moodie, John & Zyzik, Isidor & & $\mathrm{H} 2: 605$ \\
\hline $4(692)$ & 09 & $8 / 13 / 1855$ & 1725 & Beck, Joseph H. & Longworth, Nicholas & 13 of 16 lots & $\mathrm{N} 1: 226$ \\
\hline $4(692)$ & 09 & $6 / 26 / 1890$ & 4400 & Longworth, Nicholas (estate) & Dullnig, George & 3 of 4 lots & $64: 373$ \\
\hline $4(692)$ & 09 & $11 / 11 / 1890$ & 1500 & Dullnig, George & McAllister, Ida C. & 1 of 2 lots & $85: 120$ \\
\hline $4(692)$ & 10 & $8 / 13 / 1855$ & 1725 & Beck, Joseph H. & Longworth, Nicholas & 14 of 16 lots & $\mathrm{N} 1: 226$ \\
\hline $4(692)$ & 10 & $6 / 26 / 1890$ & 4400 & Longworth, Nicholas (estate) & Dullnig, George & 4 of 4 lots & $64: 373$ \\
\hline $4(692)$ & 10 & $11 / 11 / 1890$ & 1500 & Dullnig, George & McAllister, Ida C. & 2 of 2 lots & $85: 120$ \\
\hline $4(692)$ & 11 & $7 / 11 / 1859$ & 75 & Beck, Joseph H. & Achterberg, Frederick & & $\mathrm{H} 2: 151$ \\
\hline $4(692)$ & 11 & $2 / 9 / 1865$ & 500 & Achterberg, Frederick & Rudeman, Magdalene & & $\mathrm{T} 2: 684$ \\
\hline $4(692)$ & 12 & $4 / 12 / 1859$ & 75 & Beck, Joseph H. & Bohn, William & & S2:223 \\
\hline $4(692)$ & 13 & $3 / 5 / 1859$ & 130 & Beck, Joseph H. & Cush, John & 1 of 2 lots & $\mathrm{S} 1: 517$ \\
\hline $4(692)$ & 14 & $3 / 5 / 1859$ & 130 & Beck, Joseph H. & Cush, John & 2 of 2 lots & S1:517 \\
\hline $4(692)$ & 15 & $9 / 29 / 1857$ & 100 & Beck, Joseph H. & Rahm, Robert & & $\mathrm{P} 1: 481$ \\
\hline $4(692)$ & 16 & $3 / 2 / 1853$ & & Beck, Joseph $\mathrm{H}$. & Smythe, W. S. & & $\mathrm{J} 2: 388$ \\
\hline $4(692)$ & 16 & $1 / 5 / 1858$ & 1 & Beck, Joseph H. & O' Bannon, L. W. & & $\mathrm{P} 2: 436$ \\
\hline $5(688)$ & 01 & 7/27/1856 & 125 & Beck, Joseph H. & Zimmerman, Charles & & $01: 648$ \\
\hline $5(688)$ & 01 & $2 / 17 / 1857$ & 140 & Beck, Joseph H. & Droitcourt, Jacob & 1 of 2 lots & 02:401 \\
\hline $5(688)$ & 01 & $3 / 2 / 1865$ & & Zimmerman, Carl & Achterberg, Frederick & & $\mathrm{T} 2: 748$ \\
\hline $5(688)$ & 01 & $2 / 16 / 1870$ & & Achterberg, Frederick & Chieslik, Anton & 1 of 2 lots & $6: 585$ \\
\hline $5(688)$ & 02 & $1 / 8 / 1855$ & 100 & Beck, Joseph H. & Zimmerman, Charles & & G2:307 \\
\hline $5(688)$ & 02 & $2 / 17 / 1857$ & 140 & Beck, Joseph H. & Droitcourt, Jacob & 2 of 2 lots & O2:401 \\
\hline $5(688)$ & 02 & $2 / 16 / 1870$ & & Achterberg, Frederick & Chieslik, Anton & 2 of 2 lots & $6: 585$ \\
\hline $5(688)$ & 03 & $1 / 8 / 1855$ & 100 & Beck, Joseph H. & Golow, Zachius & & G2:309 \\
\hline $5(688)$ & 04 & $4 / 14 / 1857$ & 60 & Beck, Joseph H. & Nicosh, Frantz & & $02: 603$ \\
\hline $5(688)$ & 05 & $7 / 9 / 1859$ & 308 & Beck, Joseph H. & Wozgsey, Rochus & 1 of 4 lots & $\mathrm{R} 1: 459$ \\
\hline $5(688)$ & 06 & $7 / 9 / 1859$ & 308 & Beck, Joseph H. & Wozgsey, Rochus & 2 of 4 lots & $\mathrm{R} 1: 459$ \\
\hline $5(688)$ & 07 & $7 / 9 / 1859$ & 308 & Beck, Joseph H. & Wozgsey, Rochus & 3 of 4 lots & $\mathrm{R} 1: 459$ \\
\hline $5(688)$ & 07 & $4 / 17 / 1865$ & 100 & Wozgsey, Rochus & Wietzel, Jacob & 1 of 2 lots & $\mathrm{T} 1: 388$ \\
\hline $5(688)$ & 08 & $7 / 9 / 1859$ & 308 & Beck, Joseph H. & Wozgsey, Rochus & 4 of 4 lots & $\mathrm{R} 1: 459$ \\
\hline $5(688)$ & 08 & $4 / 17 / 1865$ & 100 & Wozgsey, Rochus & Wietzel, Jacob & 2 of 2 lots & $\mathrm{T} 1: 388$ \\
\hline $5(688)$ & 09 & $10 / 7 / 1856$ & 75 & Beck, Joseph H. & Hubner, Joseph & & $01: 467$ \\
\hline $5(688)$ & 09 & $5 / 251857$ & 100 & Hubner, Joseph & Altmann, Anton & & $02: 231$ \\
\hline
\end{tabular}




\begin{tabular}{|c|c|c|c|c|c|c|c|}
\hline Block & Lot & Date & $\$$ & Grantor & Grantee & Notes & BCDR \\
\hline $5(688)$ & 09 & $9 / 271859$ & 125 & Altmann, Anton & Bitter, Phillip & & $\mathrm{R} 1: 598$ \\
\hline $5(688)$ & 09 & $3 / 16 / 1867$ & 400 & $\begin{array}{l}\text { Bitter, Phillip } \\
\text { (New Braunfels) }\end{array}$ & $\begin{array}{l}\text { Reeb, August } \\
\text { (New Braunfels) }\end{array}$ & 1 of 2 lots & U1:358 \\
\hline $5(688)$ & 10 & $9 / 8 / 1854$ & 225 & Beck, Joseph H. & McDermott, Thomas & 1 of 2 lots & M2:263 \\
\hline $5(688)$ & 10 & $6 / 23 / 1856$ & 250 & McDermott, Thomas & Lasterie, James & 1 of 2 lots & O1:199 \\
\hline $5(688)$ & 10 & $12 / 22 / 1856$ & 210 & Lasterie, James & Richards, Jacob B. & 1 of 2 lots & P1:178 \\
\hline $5(688)$ & 10 & $7 / 24 / 1858$ & 300 & $\begin{array}{l}\text { Richards, Jacob B. \& } \\
\text { Margaret }\end{array}$ & Harris, Samuel & 1 of 2 lots & $\mathrm{R} 2: 117$ \\
\hline $5(688)$ & 10 & $5 / 5 / 1859$ & 180 & Harris, Samuel & Wilkins, John & & $\mathrm{R} 1: 369$ \\
\hline $5(688)$ & 10 & $3 / 16 / 1867$ & 400 & $\begin{array}{l}\text { Bitter, Phillip } \\
\text { (New Braunfels) }\end{array}$ & $\begin{array}{l}\text { Reeb, August } \\
\text { (New Braunfels) }\end{array}$ & 2 of 2 lots & $\mathrm{U} 1: 358$ \\
\hline $5(688)$ & 10 & $4 / 10 / 1872$ & $900 ?$ & Reeb, August & Bitter, Wilhelm & & W1:539 \\
\hline $5(688)$ & 11 & $1 / 7 / 1858$ & 265 & Beck, Joseph H. & Taylor, P. C. & 2 of 5 lots & $\mathrm{P} 2: 378$ \\
\hline $5(688)$ & 12 & $1 / 7 / 1858$ & 265 & Beck, Joseph H. & Taylor, P. C. & 3 of 5 lots & $\mathrm{P} 2: 378$ \\
\hline $5(688)$ & 13 & $12 / 9 / 1859$ & 1 & Beck, Joseph H. & St. Mark Episcopal Parish & & $\mathrm{R} 1: 643$ \\
\hline $5(688)$ & 14 & $6 / 19 / 1855$ & 100 & Beck, Joseph H. & Phyans, Martin & & $\mathrm{N} 1: 98$ \\
\hline $5(688)$ & 15 & half3/1854 & 100 & Beck, Joseph H. & Kraus, John & & $\mathrm{L} 2: 185$ \\
\hline $5(688)$ & 15 & $7 / 31 / 1855$ & 300 & Kraus, John & Kraudelt, August & & $\mathrm{N} 1: 129$ \\
\hline $5(688)$ & 16 & $9 / 8 / 1854$ & 225 & Beck, Joseph H. & McDermott, Thomas & 2 of 2 lots & M2:263 \\
\hline $5(688)$ & 16 & $6 / 23 / 1856$ & 250 & McDermott, Thomas & Lasterie, James & 2 of 2 lots & $01: 199$ \\
\hline $5(688)$ & 16 & $12 / 221856$ & 210 & Lasterie, James & Richards, Jacob B. & 2 of 2 lots & $\mathrm{P} 1: 178$ \\
\hline $5(688)$ & 16 & $7 / 24 / 1858$ & 300 & $\begin{array}{l}\text { Richards, Jacob B. \& } \\
\text { Margaret }\end{array}$ & Harris, Samuel & 2 of 2 lots & R2:117 \\
\hline $5 \mathrm{~N}(873)$ & 03 & $7 / 6 / 1857$ & 75 & Beck, Joseph H. & Jenison, Rufus & & $02: 291$ \\
\hline $5 N(873)$ & 04 & $6 / 28 / 1858$ & 200 & Beck, Joseph H. & Harris, James & & $\mathrm{P} 2: 472$ \\
\hline $5 N(873)$ & 05 & $1 / 7 / 1858$ & 265 & Beck, Joseph H. & Taylor, P. C. & 4 of 5 lots & $\mathrm{P} 2: 378$ \\
\hline $5 \mathrm{~N}(873)$ & 06 & $1 / 7 / 1858$ & 265 & Beck, Joseph H. & Taylor, P. C. & 5 of 5 lots & $\mathrm{P} 2: 378$ \\
\hline $5 \mathrm{~N}(873)$ & 07 & $2 / 26 / 1858$ & 150 & Beck, Joseph H. & Mullane, James \& Catharine & 1 of 2 lots & $\mathrm{P} 2: 526$ \\
\hline $5 N(873)$ & 08 & $2 / 26 / 1858$ & 150 & Beck, Joseph H. & Mullane, James \& Catharine & 2 of 2 lots & $\mathrm{P} 2: 526$ \\
\hline $6(689)$ & 01 & half8/1859 & 175 & Beck, Joseph H. & Tynan, Walter C. & 1 of 2 lots & $\mathrm{R} 2: 525$ \\
\hline $6(689)$ & 01 & $8 / 13 / 1859$ & 225 & Tynan, Walter C. & Cuff, William & 1 of 2 lots & $\mathrm{R} 1: 553$ \\
\hline $6(689)$ & 01 & $9 / 12 / 1865$ & 300 & Cuff, William & Dobrowolsky, Carl & 1 of 2 lots & $\mathrm{T} 2: 5$ \\
\hline $6(689)$ & 01 & $3 / 10 / 1890$ & 1100 & \begin{tabular}{|l} 
Dobrowolski, William \& \\
Edward \\
\end{tabular} & Kulawik, Blas & 1 of 2 lots & $70: 210$ \\
\hline $6(689)$ & 02 & $3 / 2 / 1853$ & & Beck, Joseph H. & Smythe, W. S. & & $\mathrm{J} 2: 388$ \\
\hline $6(689)$ & 02 & half8/1859 & 175 & Beck, Joseph H. & Tynan, Walter C. & 2 of 2 lots & $\mathrm{R} 2: 525$ \\
\hline $6(689)$ & 02 & $8 / 13 / 1859$ & 225 & Tynan, Walter C. & Cuff, William & 2 of 2 lots & $\mathrm{R} 1: 553$ \\
\hline $6(689)$ & 02 & $9 / 12 / 1865$ & 300 & Cuff, William & Dobrowolsky, Carl & 2 of 2 lots & $\mathrm{T} 2: 5$ \\
\hline
\end{tabular}




\begin{tabular}{|c|c|c|c|c|c|c|c|}
\hline Block & Lot & Date & $\$$ & Grantor & Grantee & Notes & BCDR \\
\hline $6(689)$ & 02 & $3 / 10 / 1890$ & 1100 & $\begin{array}{l}\text { Dobrowolski, William \& } \\
\text { Edward }\end{array}$ & Kulawik, Blas & & $70: 210$ \\
\hline $6(689)$ & 03 & $2 / 2 / 1859$ & 376 & Beck, Joseph H. & Abat, Emil & 5 of 8 lots & $\mathrm{R} 1: 223$ \\
\hline $6(689)$ & 03 & $7 / 25 / 1859$ & 480 & Abat, Emil & Maureaux, Paul & 5 of 8 lots & $\mathrm{R} 1: 476$ \\
\hline $6(689)$ & 03 & $2 / 11 / 1860$ & 400 & Maureaux, Paul & McConnell, John M. & 1 of 4 lots & $\mathrm{H} 2: 242$ \\
\hline $6(689)$ & 03 & $4 / 20 / 1860$ & 117 & McConnell, John & Murphy, John & 1 of 2 lots & $\mathrm{S} 1: 217$ \\
\hline $6(689)$ & 03 & $4 / 20 / 1860$ & 117 & McConnell, John & Murphy, John & 2 of 2 lots & S1:217 \\
\hline $6(689)$ & 03 & $12 / 17 / 1860$ & 550 & Murphy, John and Catherine & Cassidy, Miles & & S1:539 \\
\hline $6(689)$ & 04 & $2 / 2 / 1859$ & 376 & Beck, Joseph H. & Abat, Emil & 6 of 8 lots & R1:223 \\
\hline $6(689)$ & 04 & $7 / 25 / 1859$ & 480 & Abat, Emil & Maureaux, Paul & 6 of 8 lots & $\mathrm{R} 1: 476$ \\
\hline $6(689)$ & 04 & $2 / 11 / 1860$ & 400 & Maureaux, Paul & McConnell, John M. & 2 of 4 lots & $\mathrm{H} 2: 242$ \\
\hline $6(689)$ & 04 & $3 / 26 / 1860$ & 110 & McConnell, John & Fuhrmeister, Henriech & & H2:244 \\
\hline $6(689)$ & 05 & $2 / 2 / 1859$ & 376 & Beck, Joseph H. & Abat, Emil & 7 of 8 lots & R1:223 \\
\hline $6(689)$ & 05 & $7 / 25 / 1859$ & 480 & Abat, Emil & Maureaux, Paul & 7 of 8 lots & $\mathrm{R} 1: 476$ \\
\hline $6(689)$ & 05 & $2 / 11 / 1860$ & 400 & Maureaux, Paul & McConnell, John M. & 3 of 4 lots & $\mathrm{H} 2: 242$ \\
\hline $6(689)$ & 05 & $4 / 17 / 1860$ & 110 & McConnell, John & Cassidy, Miles & & $\mathrm{H} 2: 435$ \\
\hline $6(689)$ & 06 & $2 / 2 / 1859$ & 376 & Beck, Joseph H. & Abat, Emil & 8 of 8 lots & $\mathrm{R} 1: 223$ \\
\hline $6(689)$ & 06 & $7 / 25 / 1859$ & 480 & Abat, Emil & Maureaux, Paul & 8 of 8 lots & $\mathrm{R} 1: 476$ \\
\hline $6(689)$ & 06 & $2 / 11 / 1860$ & 400 & Maureaux, Paul & McConnell, John M. & 4 of 4 lots & $\mathrm{H} 2: 242$ \\
\hline $6(689)$ & 06 & $3 / 26 / 1860$ & 100 & McConnell, John M. & Ochko, Franz & & $\mathrm{H} 2: 243$ \\
\hline $6(689)$ & 07 & $2 / 21 / 1859$ & 493 & Beck, Joseph H. & Lyons, Isaac J. & 8 of 9 lots & $\mathrm{R} 1: 248$ \\
\hline $6(689)$ & 08 & $2 / 21 / 1859$ & 493 & Beck, Joseph H. & Lyons, Isaac J. & 9 of 9 lots & $\mathrm{R} 1: 248$ \\
\hline $6(689)$ & 09 & $12 / 28 / 1859$ & 175 & Beck, Joseph H. & Cleveland, William $\mathrm{H}$. & 1 of 3 lots & $\mathrm{R} 1: 660$ \\
\hline $6(689)$ & 10 & $12 / 28 / 1859$ & 175 & Beck, Joseph H. & Cleveland, William $\mathrm{H}$. & 2 of 3 lots & $\mathrm{R} 1: 660$ \\
\hline $6(689)$ & 11 & $12 / 28 / 1859$ & 175 & Beck, Joseph H. & Cleveland, William $\mathrm{H}$. & 3 of 3 lots & $\mathrm{R} 1: 660$ \\
\hline $6(689)$ & 12 & $3 / 29 / 1854$ & 84 & Beck, Joseph H. & Bourke, M. & fractional block & M2:49 \\
\hline $6(689)$ & 14 & $1 / 4 / 1859$ & 375 & Beck, Joseph H. & French, John C. & 1 of 5 lots & $\mathrm{R} 2: 488$ \\
\hline $6(689)$ & 15 & $3 / 14 / 1855$ & 164 & Beck, Joseph H. & Taylor, $\mathrm{H}$. & 1 of 2 lots & G2:379 \\
\hline $6(689)$ & 16 & $7 / 9 / 1859$ & 300 & Beck, Joseph H. & Bowen, Samuel & 1 of 3 lots & $\mathrm{H} 2: 150$ \\
\hline $6(689)$ & 17 & $7 / 9 / 1859$ & 300 & Beck, Joseph H. & Bowen, Samuel & 2 of 3 lots & $\mathrm{H} 2: 150$ \\
\hline $6(689)$ & 18 & $7 / 9 / 1859$ & 300 & Beck, Joseph H. & Bowen, Samuel & 3 of 3 lots & $\mathrm{H} 2: 150$ \\
\hline $6(689)$ & 19 & $8 / 13 / 1855$ & 1725 & Beck, Joseph H. & Longworth, Nicholas & 15 of 16 lots & $\mathrm{N} 1: 226$ \\
\hline $6(689)$ & 19 & $7 / 10 / 1890$ & 1400 & Longworth, Nicholas (estate) & $\begin{array}{l}\text { Shook, John R. \& } \\
\text { F. F. Vanden Haenen }\end{array}$ & 1 of 2 lots & $71: 181$ \\
\hline $6(689)$ & 20 & $8 / 13 / 1855$ & 1725 & Beck, Joseph H. & Longworth, Nicholas & 16 of 16 lots & $\mathrm{N} 1: 226$ \\
\hline $6(689)$ & 20 & $7 / 10 / 1890$ & 1400 & Longworth, Nicholas (estate) & $\begin{array}{l}\text { Shook, John R. \& } \\
\text { F. F. Vanden Haenen }\end{array}$ & 2 of 2 lots & $71: 181$ \\
\hline
\end{tabular}




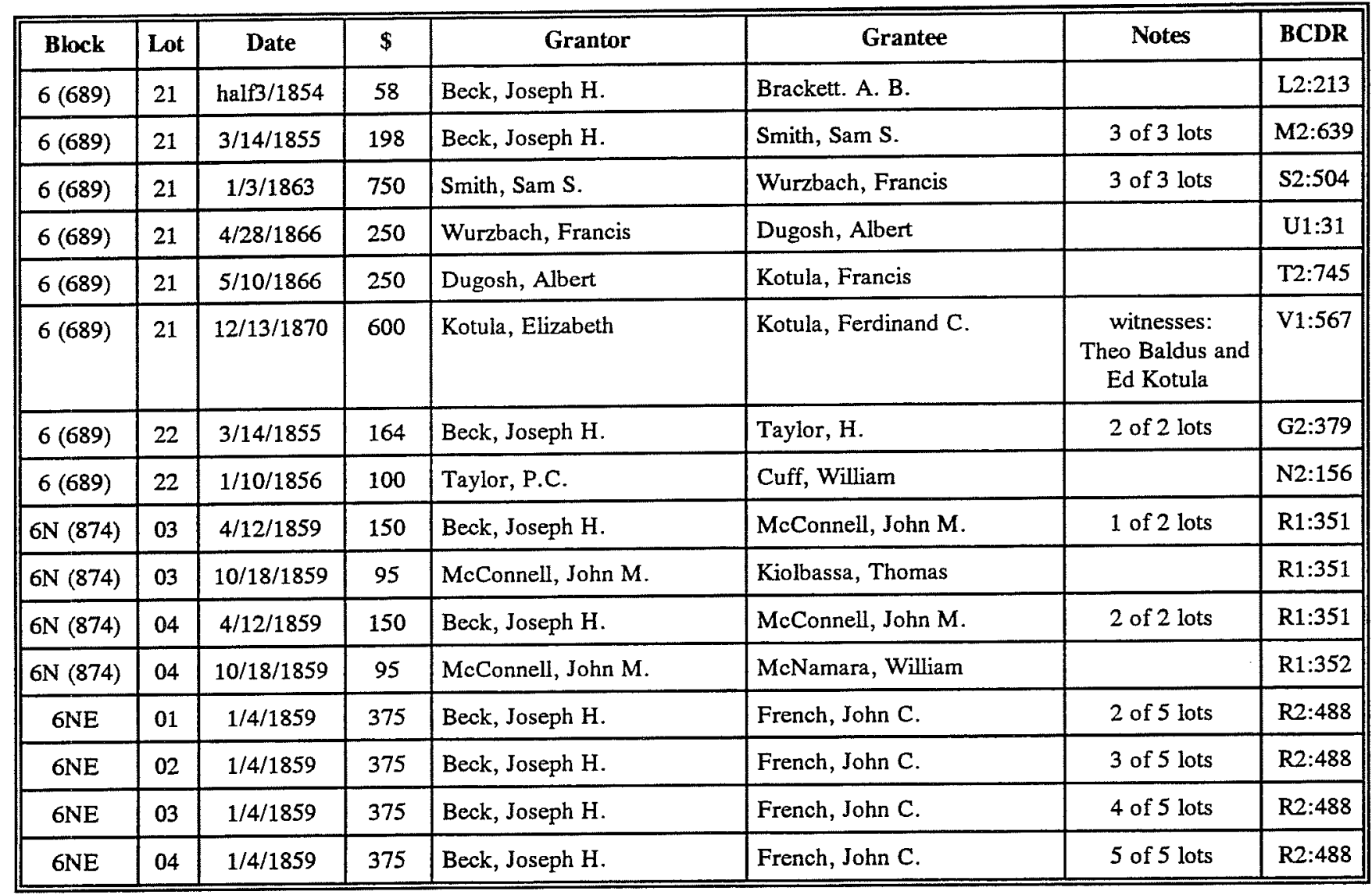



